Universidade de São Paulo

Faculdade de Filosofia, Letras e Ciências Humanas

Departamento de História

Programa de Pós-Graduação em História Social

\title{
A CONSTRUÇÃO DE UMA IDENTIDADE NACIONAL BRASILEIRA EM VISÕES ESTRANGEIRAS (1808-1822)
}

Elis Pacífico Silva

Versão Corrigida

São Paulo

2015 
Universidade de São Paulo

Faculdade de Filosofia, Letras e Ciências Humanas

Departamento de História

Programa de Pós-Graduação em História Social

\section{A CONSTRUÇÃO DE UMA IDENTIDADE NACIONAL BRASILEIRA EM VISÕES ESTRANGEIRAS (1808-1822)}

Elis Pacífico Silva

Dissertação de mestrado apresentada ao Programa de Pós-Graduação em História Social da Faculdade de Filosofia, Letras e Ciências Humana da Universidade de São Paulo (FFLCH - USP), sob orientação do Prof $^{\circ} \operatorname{Dr}^{\circ}$ João Paulo Garrido Pimenta

Versão Corrigida 


\section{Agradecimentos}

Esta pesquisa contou, durante dois anos, com o financiamento da Coordenação de Aperfeiçoamento de Pessoal de Nível Superior (Capes).

Meus agradecimentos aos professores Karen Macknow Lisboa, Marcos A. Pamplona e Amilcar Torrão Filho, pelas críticas que enriqueceram e ainda irão enriquecer meu trabalho.

Ao professor e orientador João Paulo G. Pimenta, a minha imensa gratidão. Primeiro, por me acolher na empreitada do mestrado e pela confiança que depositou em mim, segundo, pela generosa disponibilidade em oferecer uma excelente orientação.

Aos amigos, os antigos, parceiros da vida e família que escolhi, e os novos, que se tornaram especiais e são também pessoas importantes na minha formação, meus agradecimentos por me incentivarem sempre a buscar o melhor e por compartilharem comigo as minhas conquistas.

A minha família, Darras, Rosangela e Raquel, pessoas a quem devo tudo, não há palavras suficientes que farão jus a minha gratidão, amor e reconhecimento. Dedico este trabalho a vocês, de todo o coração! 


\title{
Resumo
}

As identidades coletivas e sua politização, no que concerne às transformações das primeiras décadas do século XIX, são aspectos fundamentais do processo de surgimento do Brasil como uma entidade política nacional e soberana. A presença maciça de estrangeiros no Brasil, possibilitada pela abertura dos portos em 1808, produziu modificações significativas para o futuro do Império português, além de registros deixados por viajantes sobre os atributos coletivos da população residente na América portuguesa. Ao descrever as paisagens e costumes da gente e ao veicularem vocábulos que dissessem respeito a estas descrições, entende-se que estes viajantes contribuíram com o processo de formação de uma futura identidade nacional. Desse modo, pretendeu-se analisar a forma como o "ser brasileiro" foi delineado nos relatos de viajantes britânicos e franceses que estiveram no Brasil entre 1808-1822, procurando entender as possibilidades que o abrangia e que, em momento oportuno, seria capaz de revelar adesão emocional no pertencimento ao Brasil como nação.

Palavras-chave: Identidade; Nação; Viajantes estrangeiros.

\begin{abstract}
Collective identities and their politicization are crucial aspects in the process of Brazil appearance as a national and sovereign political entity, in the transformations of the first decades of the nineteenth century. The massive presence of foreigners in Brazil, possible by the opening of the ports in 1808 , produced significant changes in the future of the Portuguese Empire, addition to records left by travelers about the collective attributes of the resident population in Portuguese America. In describing the landscapes and customs of the people and to convey words that say about these descriptions, it is understood that these travelers contributed to the formation process of a future national identity. Therefore, we intend to analyze how "being Brazilian" was outlined in reports from French and English travelers who visited Brazil between 18081822, trying to understand the possibilities that covered and that, at an appropriate time, be able to reveal the emotional attachment belonging to Brazil as a nation.
\end{abstract}

Key-words: Identity; Nation; Foreign travelers. 


\section{Sumário}

Introdução

p. 6.

Capítulo I - Os viajantes estrangeiros e o Brasil das primeiras décadas do século XIX

1.1 - (Des)Continuidades na literatura de viagem e os viajantes oitocentistas ..... p. 27.

1.2 - Visões de mundo, espaços e experiências vividas 42.

Capítulo II - Brasil e brasileiros: identidades coletivas nos discursos dos viajantes estrangeiros

2.1 - A questão nacional e o Estado nos relatos de viagem p.66.

2.2 - Os viajantes e os "brasileiros" p.91.

Conclusão. p. 133.

Fontes e Bibliografia p. 136. 


\section{Introdução}

As nações estiveram, pelo menos desde o século XVI, inseridas no universo linguístico dos indivíduos. Estas, dependendo do tempo no qual existiram, poderiam indicar origens míticas e longínquas, um momento particular do desenvolvimento de uma sociedade, o ajustamento político de uma comunidade específica ou, ainda, a conformação de características culturais de um grupo humano. Qualquer que seja a perspectiva, as variáveis que dão inteligibilidade ao termo fazem das nações esse fenômeno de difícil consenso analítico, e que permeia o mundo contemporâneo em roupagens diferentes das de outras épocas, indicando ao menos, a transitoriedade ou coexistência de seus significados. Segundo Benedict Anderson, é difícil imaginar algum fenômeno político em torno do qual haja menos consenso analítico, devido à dificuldade de "conciliar sua universalidade com sua necessária particularidade concreta". Segundo o autor, ninguém parece ter sido capaz de mostrar, de modo cabal, sua modernidade ou antiguidade, e a probabilidade de encontrar os autores que dela trataram de costas uns para os outros é maior do que o logro de uma definição em comum ${ }^{1}$. Isto, ao contrário de indicar incoerência, nos permite, enquanto pesquisadores sociais, abarcar questões tão importantes quanto diversas da constituição da sociedade humana, interpretando e historicizando tal diversidade e, em decorrência, o próprio fenômeno nacional.

No contexto do Antigo Regime, a nação enquanto entidade política tinha o poder de organizar e dar coesão a um conjunto de estruturas administrativas e de lealdades políticas que compunham a monarquia. ${ }^{2}$ No plano das representações, esta aglomerava num mesmo grupo humano indivíduos que volitavam em torno do rei, que por sua vez, era elemento central de uma organização política que mantinha relações externas com outros Estados Monárquicos. A expansão ultramarina europeia, uma das características da Idade Moderna, deu início a um novo patamar nas relações entre os Estados e em

\footnotetext{
${ }^{1}$ Benedict Anderson. "Introdução”. In:, Gopal Balakrishnam (org.). Um mapa da questão nacional. Trad. Vera Ribeiro. Rio de Janeiro: Contraponto, 2000. p. 7. B. A obra aborda diversos aspectos sobre nação e nacionalismo, apontando as divergências e convergências do debate a partir de textos dos mais importantes teóricos da questão nacional.

2 Sobre os vínculos estabelecidos entre nação, monarquia e vassalos, ver François-Xavier Guerra. Imaginarios y valores de 1808. Modernidad y independencias: ensayos sobre las revoluciones hispánicas. Mexico: FCE. 1983. p.149-175. Uma análise sobre as mudanças no uso do termo "nação" é empreendida por José Carlos Chiaramonte. Metamorfoses do conceito de nação durante os séculos XVII e XVIII. István Jancsó (org.). Brasil: formação do Estado e da nação. São Paulo: Hucitec/Fapesp/Unijuí, 2003. p. 61-91. E uma discussão historiográfica sobre as origens e evolução do Estado Moderno está apresentada em António Manoel Hespanha. A questão do absolutismo no sistema político da época moderna. Caleidoscópio do Antigo Regime. São Paulo: Alameda, 2012. p. 117-128.
} 
suas ações mercantilistas/centralizadoras: a expansão para territórios além-mar, possível aos Estados em processo de centralização ou para aqueles efetivamente centralizados, captavam investimentos e canalizavam capitais para este grande empreendimento, transformando-os em Impérios coloniais. ${ }^{3}$ Com o poder centralizado na figura do rei e o Estado organizado, Portugal foi a primeira nação europeia a consolidar sua expansão transoceânica, que passou a ser composta por territórios difusos, metrópole, colônias e um conjunto de outros territórios de estatuto diversificado $^{4}$, interferindo, assim, na dinâmica nacional. A partir do estabelecimento de um sistema de competição interestatal, nação podia se confundir com o império português, tendo nos habitantes do Brasil - católicos e súditos do rei ${ }^{5}$ - uma base de adesão à nação portuguesa.

O termo "nação" era pouco usado até começos do século XIX; até então, havia a preferência por referências coletivas de significado um pouco diferente, como "Reino" ou "Monarquia", entendidos às vezes como sinônimo de Estado e nação, e quando empregados, abarcavam a metrópole e seus territórios ultramarinos, incluindo o Brasil, onde os grupos político-econômicos, e os súditos em geral, consideravam a nação portuguesa una e indivisível, tendo a Monarquia como referência. ${ }^{6}$

\footnotetext{
${ }^{3} \mathrm{Um}$ grande aparato histórico e analítico a respeito dos ciclos de acumulação capitalista pode ser visto em: Giovanni Arrighi. O longo século XX: dinheiro, poder e a origem de nosso tempo. Rio de Janeiro/São Paulo: Contraponto/Edusp, 1996., Immanuel Wallerstein. The Modern World System. New York: Academic Press, 1977-1989. Isto não esgota a debate em torno do quão centralizadores seriam os Estados Modernos. A discussão sobre a centralização das monarquias europeias pode ser vista em A. M. Hespanha. Poder e instituições na Europa do Antigo Regime: coletâneas de textos. Lisboa: Fundação Calouste Gulbenkian, 1984.

${ }^{4}$ Alguns autores que trabalham com a ideia de conexões, redes e dinâmica do império português são Vitorino Magalhães Godinho. Os Descobrimentos e a Economia Mundial. 4Vols. Lisboa: Presença, 1987; Luís F. Thomaz. De Ceuta a Timor. Lisboa: Difel, 1994; Luís Felipe de Alencastro. O Trato dos Viventes. São Paulo, Cia das Letras, 2000; e algumas contribuições em João Fragoso M. Fernanda Baptista \& Maria de Fátima Gouvêa (orgs.). O Antigo Regime nos Trópicos: A Dinâmica Imperial Portuguesa (séculos XVI e XVII). Rio de Janeiro: Civilização Brasileira, 2001.

${ }^{5}$ I. Jancsó retoma a ideia de que a conquista e colonização da América engendrou a transformação do conquistador/colonizador em colono, este novo agente histórico não somente da expansão dos domínios de Portugal, mas da ampliação de uma formação societária particular, que passa a tomar como sua. Segundo o autor, "o colono, fosse paulista, pernambucano ou, tardiamente, goiano ou mineiro, era português preador de índios, proprietário de multidão de homens escravizados, devassador de matas estranhíssimas, comedor de farinha de mandioca, mameluco, mulato, características resultantes da dinâmica interna das formações sociais de tipo novo que ele criou e em cujo âmbito o outro não era mais o espanhol, o francês ou o holandês, mas o índio e o africano escravizado que, mesmo organicamente integrados às sociedades em colônia, não participavam da comunidade nacional.” I. Janscó. Brasil e brasileiros- Notas sobre modelagem de significados políticos na crise do Antigo Regime português na América. Estudos Avançados, vol.22 n. 62,2008. p. 259.

6 Abordando um espaço de tempo não superior a duas gerações, 1750-1850, Marco Pamplona observa que mesmo os velhos significados de "nação" permanecendo (étnicos), os vínculos entre nação e Estado foram os que condicionaram as vozes mais representativas do choque cultural do período, fortalecendo a identificação do termo com o político e ganhando novos sentidos. Tal argumentação está baseada em análises do léxico politico registrado em dicionários da época. O Vocabulário Portuguez e Latino, do
} 
A grande inovação conceitual já começava a se esboçar a partir da Revolução Francesa e da necessidade de substituição das formas de legitimação do poder: a redefinição do léxico politico "nação" fundamentou-se na transferência dos atributos da soberania da pessoa do rei, em meio a uma ordem divina, para a nação soberana, esta nova entidade que organizava as formas políticas dos Estados territoriais e também redefinia os critérios de pertencimento à comunidade nacional que impunha, além da ampliação de atributos antigos de nação, a concepção de um contrato social entre governados e governantes. ${ }^{7}$ No marco das revoluções liberais e de independência e da crise iniciada com a invasão napoleônica da Península ibérica em 1807, que doravante marcariam as duas monarquias, a nação apresentava-se, cada vez mais, a partir de possibilidades que abrangiam os domínios da Coroa e colocava em jogo diversos sentidos do termo, seu alcance territorial, social e político. ${ }^{8} \mathrm{O}$ sentido conferido ao vocábulo a partir do momento específico vivido pela Península Ibérica, portanto, e sentido do outro lado do Atlântico produziu transformações em conceitos políticos imprescindíveis para o entendimento das concepções de pertencimento a um grupo humano diferenciado de outros, dentro do grupo de nações modernas que estavam a ser

padre Raphael Bluteau, de 1716 (oito volumes, entre 1712 e 1721), segundo o autor, já dava a definição de nação vinculada a reino, monarquia e autoridade de um mesmo senhor, ainda associada ao contexto do Antigo Regime, mas que também trazia outros sentidos prévios do termo (étnico, linguístico, origem). O Dicionário da Língua portuguesa, de Antônio de Moraes Silva, ao longo de suas várias edições, também registrava o significado antigo do vocábulo, segundo Pamplona, mas precedia de uma definição principal e mais ampla, como no dicionário de Bluteau.. Em ambos os léxicos, "el primer significado del término nación se refería a la civitas y descrebía sobre todo 'a gente de um paiz, ou região, que tem Língua, Leis e Governo á parte’. Como ejemplo concreto de essas grandes aglomeraciones de gente, políticamente organizadas, estaban citadas como 'Nação Francesa, Espanhola, Portuguesa'. consideradas como modernas, en elas se valoraba, sobre todo, el orden político, aunque fuesen admitidas la unidade de lengua y el territorio como expresiones importantes para particularizarlas.". Marco A. Pamplona. Nación. Brasil. ". In: Javier Fernández Sebastián (dir.). Diccionario político y social del mundo iberoamericano .La era de las revoluciones, 1750-1850. Fundación Carolina/Centro de Estudios Políticos y Constitucionales. Madri, 2009. p. 882-883.; F. Wasserman. "El concepto de nación e las transformaciones del orden político en Iberoamérica, 1750-1850”. In: J. F. Sebastián (dir.). Diccionario político y social..., cit, p. 857. O imaginário do rei como cabeça do corpo social tem nesta percepção de nação lugar de importância: o monarca está indissoluvelmente unido à nação. Ver em F- Xavier Guerra. Modernidad y Independencias..., cit.p. 150.

${ }^{7}$ Guilherme Pereira das Neves. A polissemia de uma palavra. Estudos ibero-americanos. vol. 10, n.1, 1984. p. 17.39 .

${ }^{8}$ F. Wasserman. El concepto de nación..., cit, p. 851 e 858. Uma análise sobre o desmoronamento dos impérios ibéricos pode ser observada em Jeremy Aldeman, que analisa a soberania imperial descentralizada como um dos elementos do colapso dos impérios Espanhol e Português. O autor argumenta que as revoluções ibero-americanas não foram a causa da desagregação imperial, mas sua consequência, colocando o movimento como parte de uma conjuntura internacional. Propõe ainda que os impérios não significavam senão as relações e transações estabelecidas entre os diversos povos que os constituíam, e que a soberania nacional não foi capaz de substituir a sua antecessora, a imperial. Jeremy Adelman, Sovereignty and Revolution in the Iberian Atlantic. Princeton: Princeton University Press, 2006. 
construídas ou, pelo menos, esboçadas em alguns de seus fundamentos, em inícios do século XIX.

Este século, tempo característico de processos e transformações políticas importantes na nova configuração da nação, principalmente no caso daquelas emergentes da crise e superação do Antigo Regime ${ }^{9}$, impulsionou a criação de organismos estatais que (re)institucionalizaram e (re)organizaram a vida social, conferindo a este momento histórico complexas configurações de novos valores e práticas sociais - e, por vezes, a reconfiguração dos velhos - e o caráter, bem designado por um historiador, de o "tempo da política". ${ }^{10}$ As unidades políticas dos impérios ibéricos nos séculos XV e XVIII, geograficamente descontínuas, eram bem delimitadas somente nas porções europeias, ou nas colônias, em casos de necessidade particular, como o de territórios em disputa, por exemplo; a partir do século XIX, os referenciais de identidade destas sociedades multifacetadas foram reorganizados em novas redes de lealdade política, que do ponto de vista administrativo estavam amparadas por ideias gerais que homogeneizavam áreas muito heterogêneas. ${ }^{11}$ Nesta perspectiva, o ambiente dos oitocentos norteou a prática de pressupostos e novas formas de cultura política profícuas à formação de nações independentes e, agora, também soberanas.

Neste processo de surgimento do Brasil como uma entidade política nacional e soberana, o estudo da constituição de identidades coletivas e sua politização é um dos vetores essenciais para o entendimento da formação nacional centrada no surgimento de uma expressão vocabular totalizadora, a indicar a existência de uma comunidade de "brasileiros", em meio a um processo que a historiografia, em geral, caracteriza "corretamente" como distante de definições precisas, sólidas e estáveis. O termo resumiria a noção de pertencimento a uma comunidade ao mesmo tempo deslocada e oriunda do mesmo braço da comunidade de portugueses europeus. As feições coloniais, sempre em transformação, que deram por três séculos os contornos característicos do

\footnotetext{
${ }^{9}$ Um enquadramento geral clássico do Antigo Regime e sua crise é dado por Fernando A. Novais. Portugal e Brasil na crise do Antigo Sistema Colonial (1777-1808). São Paulo: Hucitec, 1979. Críticas contundentes à proposta de Novais encontram-se, dentre outros, em João Fragoso. Homens de grossa ventura. Rio de Janeiro: Arquivo Nacional, 1992.

${ }^{10}$ No século XIX, a política passa a agir em praticamente todos os interstícios das sociedades, surgindo desta reflexão a obra de Elias Palti, que entende por este tempo aquele em que novas legitimidades se fundam. E. Palti. El tiempo de la política. El siglo XIX reconsiderado. Buenos Aires: Siglo XXI Editores Argentina, 2007.p. 13-14.

${ }^{11}$ João Paulo G. Pimenta. Estado e Nação no fim dos impérios ibéricos no Prata (1808-1828). São Paulo: Hucitec; Fapesp, 2002. p. 20.
} 
Brasil, estavam a partir do século XIX alterando a dinâmica do império português e, por sua vez, a das identidades coletivas que compunham este império de múltiplas feições.

Neste contexto, o ano de 1808, primeira demarcação temporal desta pesquisa, é considerado pela historiografia um marco cronológico que potencializou algumas das mais importantes transformações ocorridas nas colônias luso americanas. O bloqueio continental, decreto datado de 1806 que estabelecia o fechamento de todos os portos da Europa para os britânicos, e as invasões napoleônicas que colocaram o Império português intimamente entrelaçado com a política externa da Grã-Bretanha, doravante sua protetora, implicou na transferência da Corte e sua instalação no Rio de Janeiro, provocando profundas alterações sentidas tanto pelas porções coloniais do império português quanto pela metrópole ${ }^{12}$, reajustando-se a dinâmica estabelecida entre as partes. Assim, desdobramentos dessa conjuntura, tal qual a abertura dos portos do Brasil ao comércio com outras nações, permitiram ao país experiências extraordinárias vivenciadas em menos de duas décadas, conferindo especialmente ao Rio de Janeiro, importância tanto nas decisões internas do império ${ }^{13}$, quanto no cenário internacional.

Estas mudanças implicaram a presença maciça, no Novo Mundo, de muitos viajantes, fossem estes encarregados de negócios, a serviços formais de Estados estrangeiros, artistas ou motivados por qualquer outro pretexto que os impulsionasse a visitar o Brasil da época. A vinda da Corte, segundo Sérgio Buarque de Holanda, teria ajudado os naturais da terra a julgarem seus "dominadores" com melhor senso de realidade ao impor o convívio forçado com os estrangeiros ${ }^{14}$. Segundo o autor, "nunca nosso país parecera tão atraente aos geógrafos, aos naturalistas, aos economistas, ao simples viajante, como naqueles anos que imediatamente se seguem à instalação da Corte portuguesa no Rio e à abertura dos portos ao comércio internacional", dotando tal cidade de considerável cosmopolitismo. ${ }^{15}$

\footnotetext{
${ }^{12}$ Valentim Alexandre. Os sentidos do Império: questão nacional e questão colonial na crise do Antigo Regime português. Porto: Afrontamento, 1993. p. 175-177. Ver também Jurandir Malerba. A corte no exílio. Civilização e poder no Brasil às vésperas da independência (1808-1821). São Paulo: Companhia das Letras, 2000.; Andrea Slemian \& João Paulo G. Pimenta. A corte e o mundo. Uma história do ano em que a família real portuguesa chegou ao Brasil. São Paulo: Alameda, 2008.

${ }^{13}$ Maria de Fátima Gouvêa. O império das províncias. Rio de Janeiro (1822-1889). Rio de Janeiro: Faperj, 2006. A autora realiza análise da força e relevância dos grupos políticos e econômicos espalhados pelo interior das províncias e as conexões que os interligavam tanto ao governo provincial, quanto à sede do governo, instalado no Rio de Janeiro a parir de 1808.

${ }^{14}$ Sérgio Buarque de Holanda. A herança colonial - sua desagregação. História geral da civilização brasileira t. II. O Brasil monárquico. São Paulo: Difel, 1962. p. 11.

${ }^{15}$ Ibidem, p. 11-12. Carlos G. Mota também aponta que "as três primeiras décadas do século XIX [...] já alteravam substancialmente o metabolismo da vida da colônia”, observando ainda o caráter cosmopolita adquirido pelo Brasil e o choque de mentalidades que acompanhava esse fluxo. Carlos G. Mota. Europeus
} 
A translação do centro de governo de Portugal para o Brasil foi possibilidade discutida há muito e retomada por Rodrigo de Souza Coutinho em 1803, que apontou a importância do Brasil para o conjunto do império português, reconhecido pelo ministro como a "melhor parte da monarquia". ${ }^{16}$ Abertos os portos a partir da transferência do centro de governo para o Rio de Janeiro, viajantes oriundos de várias nacionalidades, principalmente da Grã-Bretanha, a quem primeiro coube os privilégios desta abertura, arremataram o status de importância que o Brasil vinha adquirindo nos âmbitos políticos do império lusitano e de outras potências europeias. Os discursos que os viajantes estrangeiros produziram ao passarem pelo país nas primeiras décadas dos oitocentos constituem, portanto, rico material no que concerne à possibilidade de percepção com relação dos habitantes da América portuguesa. As bagagens culturais diversificadas destes indivíduos, somadas a uma visão externalizada das características do Brasil, além de garantirem um ponto de referência na compreensão da multiplicidade de identidades já disponíveis no início do século XIX, produziram expressões identitárias remetidas às coletividades sociais que logo tornar-se-iam parte integrante de uma nação brasileira que ainda era inexistente. Eles deixaram registros importantes que, como trata Karen M. Lisboa, contribuíram para a construção da imagem do Brasil como nação ${ }^{17}$, mais precisamente uma identidade coletiva a ela referida, sintetizada no termo "brasileiro" de forma contundente por esses indivíduos.

\footnotetext{
no Brasil à época da independência. Um estudo. In: C. G. Mota (org.) 1822: dimensões. São Paulo: Perspectiva, 1972. p. 58-60.

${ }^{16} \mathrm{Em} 1580$ foi dado ao pretendente ao trono português o conselho de transferência da sede de governo para o Brasil, estabelecendo ali um grande império. No reinado de D. João V (1707-1750), d. Luís da Cunha, em 1738, percebendo as riquezas do Brasil e seu papel no território lusitano, aconselhou a transferência de rei para a colônia. Ao temer invasão do reino por tropas francesas, em 1762, marquês de Pombal deixou de sobreaviso uma esquadra que traria o rei D. José I ao Brasil. Já em 1801, quando fracassavam as potências europeias contra as investidas de Napoleão e a diplomacia francesa fazia pressões sobre Portugal, implicando a perda de sua soberania, o marquês de Alorna aconselhou o príncipe regente a ameaçar transferir-se para o Brasil, no sentido de intimidação diante da disposição de "ir ser imperador naquele vasto território onde pode[ria] facilmente conquistar as colônias espanholas e aterrar em pouco tempo todas as potências europeias". Luís Carlos Villalta. 1789-1808. O império lusobrasileiro e os Brasis. São Paulo: Companhia das letras, ano. p. 32-33.

${ }^{17}$ Karen M. Lisboa. Os olhos estrangeiros sobre o Brasil do século XIX. In: Viagem Incompleta: a experiência Brasileira (1500-2000). São Paulo: Ed. Senac São Paulo, 2000. p. 268. Outras análise dos viajantes e a construção de uma imagem sobre o Brasil pode ser vista também em Flora Medeiros Lahuerta. Viajantes e a construção de uma ideia de Brasil no ocaso da colonização (1808-1822). Revista eletronica de geografias y ciências sociales. vol. X, n. 218 (64), 2006.; Wilma Peres Costa. Viajantes europeus e o escrever da nação brasileira. In: Marco A. Pamplona \& Don Doyle (orgs.) Nacionalismos no novo mundo - a formação de Estados-nação no século XIX. Rio de Janeiro: Record, 2008. Ver também a abordagem do processo de transculturação, no qual se dá a auto representação europeia pelo confronto da imagem do "outro", em: Antonello Gerbi. O novo mundo: história de uma polêmica. São Paulo: Cia das Letras, 1996 e Mary Louise Pratt. Os olhos do império. Trad. De Zézio Gutierre. São Paulo: Edusp, 1999.
} 
Esta pesquisa procurou analisar as expressões vocabulares empregadas por alguns desses viajantes estrangeiros que passaram a visitar e até mesmo residir no Brasil nas primeiras décadas do século XIX, que fizessem referência aos seus habitantes e que acabaram por denominar com certa desenvoltura o termo "brasileiro"; investigou a construção de uma identidade coletiva na América portuguesa, que neste mesmo período tornar-se-ia referência básica da nação a ser constituída no Brasil, e como tais expressões interagiram com o processo mais geral de surgimento do Estado e da nação brasileiros nas primeiras décadas do século XIX, a partir da visão dos viajantes estrangeiros.

O outro marco cronológico desta pesquisa, o ano de 1822, também acarretou ao Brasil modificações políticas importantes integrando-o aos Estados independentes que compunham o cenário americano de então. Apontado pela historiografia tradicional como um processo supostamente pacífico ${ }^{18}$, o processo de independência do Brasil teria como questão fundamental para uma parte desta produção, as permanências com relação ao passado colonial, que acabavam por diminuir o caráter revolucionário do movimento $^{19}$, ao mesmo tempo em que reproduziam uma ideia pressuposta de superioridade do caso luso americano com relação à América hispânica. ${ }^{20}$ Ainda que com a manutenção do território, da escravidão e da monarquia no processo de independência na América portuguesa, a formação do Estado nacional contou com novas formas de sociabilidade que vinham se desenrolando desde meados do século XVIII e que impuseram rachaduras irremediáveis nos moldes do Antigo Regime. ${ }^{21}$ No período de transição verificado no processo de independência, segundo Caio Padro Jr., se ainda não era o Brasil uma nação propriamente autônoma, também não era uma

\footnotetext{
${ }^{18}$ S. B. Holanda. Herança colonial - sua desagregação..., cit.; Caio Padro Jr. Evolução política do Brasil: colônia e império. $19^{a}$ ed. São Paulo: Brasiliense, 1992.

${ }^{19}$ Wilma Peres Costa. A independência na historiografia brasileira. In: I. Jancsó (org). Independência: história e historiografia. são Paulo: Hucitec/ Fapesp, 2005.

${ }^{20}$ Alguns dos autores que trabalharam com as diferenças nos processos de independência na América Ibérica: José Ribeiro Junior. O Brasil monárquico em face das repúblicas americanas. In: C. G. Mota (org.). Brasil em perspectiva. $18^{\mathrm{a}} \mathrm{ed}$. Bertrand: Rio de Janeiro, 1990. Oliveira Lima. D. João VI no Brasil. 3 ed. Rio de Janeiro: Topbooks, 1996.; C. Prado Jr. Evolução politica do Brasil..., cit. S. B. Holanda. Herança colonial - sua desagregação..., cit. Raimundo Faoro. Os donos do poder: formação do patronato político brasileiro. 3 ed. São Paulo: Globo, 2009.

${ }^{21}$ I. Jancsó. A construção dos Estados Nacionais na América Latina. Apontamentos para o estudo do império como projeto. In: Tamás Szmrecsányi \& José Roberto do Amaral Lapa (orgs.) História Econômica da Independência e do Império. 2 ed. São Paulo: Hucitec/ Associação Brasileira de Pesquisadores em História econômica/ Edusp/ Imprensa Oficial, 2002.; T. Halperín. Historia da America Latina. Reformas y disolución de los impérios ibéricos, 1750-1850. F. Novais. Portugal e Brasil..., cit. I. Jancsó. "A sedução da liberdade: cotidiano e contestação política no final do século XVIII". In: Laura de Mello e Souza (org.) História da vida privada no Brasil. São Paulo, Cia. das Letras, 1997.; Kenneth Maxwell. A Devassa da Devassa. Rio de Janeiro: Paz e Terra, 1978.
} 
colônia, ao passo que a emancipação desta teria sempre como resultado uma situação não mais compatível com os estatutos coloniais. ${ }^{22} \mathrm{O}$ processo de independência permitiu também a articulação de indivíduos que passariam num futuro próximo a ser considerados pertencentes à nação brasileira, ainda não totalmente constituída, mas que já esboçava alguns de seus fundamentos e estava presente no universo linguístico dos agentes sociais envolvidos no processo. Dentre estes, os viajantes europeus que percorreram o Brasil no recorte estabelecido na pesquisa, puderam presenciar e muitas vezes diagnosticar no contexto em que, paulatinamente, foram criadas as condições de realização da independência, e em outros acontecimentos políticos de que foram testemunhas, os sintomas de uma formação identitária.

Deve-se ter em mente que a percepção da crise do império português e as consequentes modificações ocorridas na porção americana não foram sentidas de forma uniforme e linear, mas sob várias perspectivas, e que a provisoriedade característica do período teve coexistência não apenas com as ideias em torno do Estado, mas também com relação à nação e às identidades políticas coletivas, "eventualmente reveladoras de tendências à harmonização entre si ou, quando não, expressando irredutibilidades portadoras e alto potencial de conflito." 23 A simultaneidade dos processos de criação do Estado e da nação modernos estabelece correspondência, portanto, com a perspectiva das identidades coletivas: o Estado, ao reivindicar posição entre outros corpos políticos, a partir de um determinado momento passou a ter na nação as condições históricas de identificação de um grupo político centrado em torno de um mesmo governo, tendo nas identidades o fator de coesão e sustentação de uma possível nacionalidade "brasileira". As reformas da monarquia portuguesa para centralizar o poder, a crise e desintegração deste império e a emergência de uma unidade política oriunda dos antigos domínios metropolitanos convergem para o conceito de nação, que só pode ser entendido historicamente em combinação com outros termos correlatos que lhe garantam inteligibilidade. $^{24}$ Ao menos, vocábulos políticos novos e antigos conformavam a constituição de discursos que invariavelmente corriam entre os homens que os

\footnotetext{
${ }^{22}$ C. Padro Jr. Evolução política do Brasil..., cit.1992. p. 52.

${ }^{23}$ I. Jancsó \& J. P. Pimenta. Peças de um mosaico (ou apontamentos para o estudo da emergência da identidade nacional brasileira). Revista de História das Ideias, Coimbra, v. 21, p. 389-440, 2000. p.397. Este trabalho é o que de modo mais contundente analisa essa "politização" de identidades coletivas para o caso do Brasil.

${ }^{24}$ Ver Reinhart Koselleck. História dos conceitos e história social. In: Futuro Passado: contribuição à semântica dos tempos históricos. Rio de Janeiro: Contraponto, Ed. PUC-Rio, 2006. O autor não analisa especificamente o mundo português, mas adotamos algumas das sugestões teóricas do autor, referentes a uma história dos conceitos.
} 
formulavam e que, aos poucos, difundiam nos espaços públicos seus projetos. É neste contexto que a relação dos termos Estado e nação ganha corpo e condições de redefinição de espaços políticos, abarcados, entre tantos outros aspectos passíveis de análise, os territórios, as formas de governo, de legitimação do poder e, especificamente abordada nesta pesquisa, a politização das identidades coletivas.

A transitoriedade concernente a momentos de crise, como a vivenciada por Portugal quando da invasão napoleônica e, no espectro geral, da crise do Antigo Regime, fez surgir a possibilidade de alternativas factíveis aos tradicionais vínculos coloniais com a metrópole, concretizadas somente com a independência (e depois dela), ao menos no aspecto identitário. A articulação e superposição de identidades que viriam a se politizar e angariar qualidades na formação nacional brasileira a partir das primeiras décadas do século XIX é aspecto crucial deste processo e deve ser considerada, portanto, sob o prisma da já multifacetada sociedade colonial. A importância deste processo é amplamente reconhecida pela historiografia ${ }^{25}$, que nas últimas décadas vem dando a ele contornos diversificados. Deve-se ressaltar, diante de muitas possibilidades, que o estudo cada vez mais apurado dos contornos identitários dos habitantes das possessões portuguesas na América ou de pessoas que, de diferentes modos, passaram a ser reconhecidas como vinculadas politicamente a ela, são de grande valia para o entendimento de projetos políticos que foram ganhando, aos poucos, contornos mais coesos e constituindo uma rede de significações em torno das identidades coletivas politizadas. ${ }^{26}$ A partir desta perspectiva, podemos admitir que as comunidades de pertencimento formam a trama social, sendo esta composta por corpos e estruturas políticas complexas e em movimento.

Nesse complexo processo de politização de identidades coletivas, os viajantes estrangeiros parecem ter expressado uma visão peculiar dos atributos coletivos da população residente no Brasil, formulando, a partir de prognósticos e projetos de futuro, expressões pioneiras de uma identidade brasileira que, como mostra a bibliografia, só se estabelecerá plenamente a partir da independência. ${ }^{27}$ Diante destas assertivas, nos deparamos novamente com o tema central desta pesquisa, que é o papel das expressões identitárias formuladas a partir de visões dos viajantes estrangeiros que deixaram suas impressões - e com elas, talvez algo mais - a respeito do Brasil. Deparamo-nos, então,

\footnotetext{
${ }^{25}$ I. Jancsó. A construção dos Estados nacionais na América Latina..., cit.

${ }^{26}$ I. Jancsó \& J. P. Pimenta. Peças de um mosaico..., cit.

${ }^{27}$ Vide várias contribuições em: I. Jancsó (org.). Independência: história e historiografia..., cit.; também J. Malerba. A corte no exílio..., cit.
} 
com a própria justificativa do trabalho: entendemos que as identidades são aspectos específicos da questão nacional e que, no começo do século XIX não se apresentavam com contornos bem definidos, mas logo começariam a se delinear de modo importante, inclusive impulsionadas pelo olhar estrangeiro. A perspectiva possível de ser vislumbrada através da literatura de viagem produzida por estes indivíduos pode contribuir para a apreciação de como o "outro" entendia o que era visto, vivido e experimentado no Novo Mundo, o que por seu turno ajudava a criar uma condição identitária de portugueses estabelecidos no Brasil, em meio a grandes transformações políticas, econômicas e sociais, que logo abririam locus para o surgimento e consolidação de uma identidade especifica "brasileira".

Ao atribuir ao termo nação a condição de baluarte da soberania (ou seja, no seu sentido moderno), podemos integrar o surgimento do conceito político deste a um momento específico da história recente do mundo ocidental, consequência de novas formas de organização político-social de tipo moderno. ${ }^{28}$ As revoluções políticas e o advento do capitalismo industrial estão ligados a tal tipo de organização, associando-os também à modernidade do conceito. Parte dominante desta bibliografia da chamada questão nacional tem fundamentado suas análises em generalizações importantes, por vezes válidas para a formação de uma identidade nacional brasileira. $\mathrm{O}$ caráter moderno da nação, sua contingência, neste sentido, é aspecto útil ao entendimento da questão nacional no Brasil.

No entanto, o peso da tese modernista de nação tem diminuído o enfoque de particularidades da questão nacional em ambientes que pouco a pouco se tornavam menos coloniais. Com relação ao mundo luso americano, podemos nos apoiar nas postulações de Elias Palti, ${ }^{29}$ segundo as quais, a fim de descobrir impulsos diferenciadores de cada forma particular de discurso, devemos nos remeter ao "subsolo

\footnotetext{
${ }^{28}$ F. X. Guerra. Modernidad y Independencias... cit, . p. 13-14. Esta "modernidade" é entendida pelo autor como uma nova era em que um novo homem se manifesta, criando rupturas irreversíveis na nova forma de legitimidade baseada na nação, sintetizadas naquele termo: a criação de uma nova cena púbica na qual o novo sistema de referências, que cria valores e comportamentos na configuração deste novo homem, deixa os círculos privados nos quais até então tinha sido mantido para irromper na esfera pública. Segundo o autor, o radicalmente novo não era a existência desse sistema global de referências, pois este havia surgido ao longo do século XVIII em grupos restritos de homens agrupados numa nova forma de sociabilidade.

${ }^{29}$ E. Palti. El tiempo de la política..., cit.
} 
de ideias das quais emerge", ou seja, as hipóteses científicas, doutrinas filosóficas, religiosas, linguísticas, etc., dos conceitos, devem transcender a instância textual. Palti entende, desta forma, que os historiadores erram seu alvo ao perder de vista as transformações conceituais produzidas dentro do pensamento nacionalmente orientado.

O desmoronamento do Império português na América foi vivenciado sob o espectro da provisoriedade, sendo plausível dele inferir a coexistência de identidades políticas ambíguas e pouco definidas. ${ }^{30}$. Deve-se ter em consideração que as manifestações de desagrado anunciadas sob forma de sedição denunciaram a possibilidade de crítica aberta a esse modo de vida pautada pelo absolutismo monárquico, despontando novas formas de sociabilidade, antes mesmo que as conjunturas políticas do século XIX modificassem as feições do império português. Tratava-se de problemas sem precedentes enfrentados pelo governo na América em finais dos setecentos, intimamente relacionados com o quadro geral de transformações do império português. ${ }^{31}$ Isto não implicava a ideia do surgimento de uma identidade nacional no final dos setecentos que prenunciaria o advento do Estado Nacional brasileiro $^{32}$. No entanto, aponta a coexistência de grupos de diferentes tipos no Brasil e

\footnotetext{
${ }^{30}$ I. Jancsó e J. P. Pimenta. Peças de um mosaico..., cit. A dissolução dos impérios ibéricos e a formação do Estado moderno coexistiu com uma multiplicidade de identidades políticas que sintetizavam, cada qual a sua maneira, alguma realidade e projetos políticos de diversas ordens. Segundo István Jancsó, para os homens da época, independente da região em que viviam na América ibérica, ao menos ate final do século XVIII e início do XIX, "a sua identidade política passava pelo reconhecimento ou pela negação de realidades dentre as quais o nacional era a menos nitidamente definida", sobressaindo as especificidades do local, regional e colônia e, em paralelo e em oposição, ao universo imperial e mesmo ao americano.

Em conformidade com as reflexões de I. Jancsó, J. C. Chiaramonte, que analisa o caso hispanoamericano, observa que pouco se tem atentado para a coexistência de identidades diante da ambiguidade refletida no sentimento coletivo. O processo maior, que é o da formação do Estado independente, indica a direção que se movia o processo de construção das identidades políticas. Esse ponto de vista converte a coexistência de diversas formas de identidades políticas em indicador de uma realidade social que desconhecia qualquer contorno nacional. As identidades surgem e se modificam, portanto, ao passo que os fatos se impõem, ou seja, há variação de identidades quando existe a realidade que condicione tal mudança. I. Jancsó. A construção dos estados nacionais na América Latina..., cit. p. 3.; J. C. Chiaramonte, "Formas de identidad politica em el Rio de la Plata luego de 1810."'In: Boletin del Instituto de Historia Argentina e Americana "Dr. Emilio Ravignani", 3 série, nº 1, 1989.

${ }^{31}$ Apreendidas por Fernando Novais na crise do sistema colonial, perspectiva desdobrada num primeiro momento por Guilherme Mota e desenvolvida sob a ótica da sedição por István Jancsó. F. Novais. Portugal e Brasil na crise...cit.. C. G. Mota. Atitudes de inovação no Brasil, 1789-1801. Lisboa: Livros Horizonte, 1960.; I. Jancsó. A sedução da liberdade..., cit.

${ }^{32} \mathrm{Na}$ esfera da nação, muitos historiadores concordam que o sentimento desta não está implícito no movimento de ruptura política com Portugal, alertando para a variante de anacronismos que a equivalência entre Independência e Nação pode acarretar. Segundo alguns deles, ao colocar a nação no começo do processo de ruptura política da colônia com a metrópole, o risco de deformação do processo anterior à independência, alocando todo o século XVIII americano como sintoma do surgimento da nação, é grande. No caso das possessões espanholas J. C. Chiaramonte. Modificaciones del Pacto Imperial. In: Antonio Annimo; Luis Castro Leiva, François-Xavier Guerra (dir.) De los impérios a las naciones: Iberoamérica. Zaragoza/Espanha: Ibercaja, 1994.; I. Jancsó \& J. P. G. Pimenta. Peças de um mosaico... cit.
} 
de identidades coletivas atuantes na sociedade, antes mesmo da vinda da Corte e dos processos políticos subsequentes, e que estabeleciam relações complexas com a metrópole e autoridades régias situadas na colônia. Deste modo, as manifestações do processo de formação da identidade nacional brasileira estiveram inseridas numa dinâmica que impede generalizações que imputem às identidades um caráter de uniformidade, e as mutações nas formas de se encarar a questão nacional num ambiente diverso do da Europa mostram-se fundamentais para se analisar o fenômeno de surgimento de uma identidade nacional no Brasil, nas primeiras décadas do século XIX.

A nossa análise específica do fenômeno identitário relacionado ao surgimento da nação moderna exige, portanto, a consciência de certos aspectos do mundo do qual estamos tratando. Neste sentido, ao considerar o termo como categoria histórica, estamos submetendo-o ao sentimento de comunidade a partir de acontecimentos políticos que mudaram a feição da América portuguesa no período.

Por outro lado, as identidades que se desdobram da questão nacional remetem a uma questão de linguagem, em nosso caso mais especificamente a linguagens políticas $^{33}$. Esta implica, segundo Pocock, que o que era antes conhecido como história do pensamento político, pode agora ser descrito mais precisamente como história do discurso político. Neste sentido, para que se possa dar aos discursos uma história, seria necessário que se apresentasse uma atividade ou uma continuidade de ação, "constituídas por coisas sendo feitas e coisas acontecendo". Assim, Pocock supõe "um campo de estudos constituído de atos de discurso, sejam eles orais, manuscritos ou impressos, e [as] condições ou contextos em que estes atos foram emitidos", ao passo que para cada coisa a ser dita, escrita ou impressa deve haver uma linguagem na qual ela possa ser expressa. ${ }^{34}$

Ao se abordar um aspecto da questão nacional por meio das identidades, estamos inseridos inevitavelmente neste debate, que tem a linguagem como fio condutor de um tipo específico de discurso. A atitude do historiador com relação ao discurso (político) que se predispõe a analisar deve ser, portanto, a de aprender as "linguagens", ao mesmo tempo a de estudar os atos de enunciação emitidos nestas linguagens; em seguida,

\footnotetext{
33 Ao se falar em linguagem, podemos considerá-la, de acordo com as postulações de Pocock, como sendo "idiomas, retóricas, maneiras de falar sobre política, jogos de linguagem distinguíveis", podendo ter cada uma destas "sublinguagens" suas próprias regras e implicações. J. G. A. Pocock. Linguagens do ideário político. Tradução de Fábio Fernandez. São Paulo: Edusp, 2003. p. 65.

${ }^{34}$ Ibidem, p. 64.
} 
entenderá os efeitos causados por estes atos. ${ }^{35}$ As diversas categorias que balizam o desenvolvimento da linguagem política não podem ser introduzidas diretamente sem antes transitar pelos diversos meandros em que se desdobra. ${ }^{36}$ É o que pretendemos, dentro do escopo deste trabalho, fazer.

Não é inédita a utilização da literatura de viagem como fonte para muitos estudos a respeito do Brasil do século XIX. Trabalho após trabalho, esta documentação vem sendo eleita pelos historiadores, que observam características peculiares aos escritos dos viajantes, encerrando enfoques, tão importantes quanto diversos, do olhar externo que estes indivíduos deixaram sobre os lugares visitados e seus habitantes. ${ }^{37}$ A condição de viajante perpassa diversas profissões e motivos que impulsionaram estrangeiros a escreverem sobre o que viram. "O termo 'viajante' abriga", segundo Valéria Lima, "uma significativa variedade de sentidos: explorador, naturalista, cientista, topógrafo, filósofo, historiador, até mesmo artista e escritor." Segundo ela, "as atividades e os olhares específicos a cada uma dessas ocupações revelam diferentes formas de registro

\footnotetext{
${ }^{35}$ Ibidem, p. 66.

36 A proposta da nova história intelectual, no quadro exposto por Elias Palti, está baseada na reconstituição de linguagens políticas. A problematização e construção dos conceitos feita pelo autor possibilita a percepção mais apurada dos contextos em que tais conceitos são utilizados, atribuindo lógica ao sentido das mudanças da linguagem política. Elias Palti. El tiempo de la política ..., cit. p. 17.

${ }^{37}$ Entre tantos trabalhos relativos à literatura de viagem, indicações importantes para a elaboração dessa dissertação são: Mirian L. Moreira Leite. A condição humana no século XIX no Rio de Janeiro: antologia de textos de viajantes estrangeiros. São Paulo: Hucitec/INL/Fundação Nacional Pró-Memória, 1984.; Livros de Viagem (1803-1900). Rio de Janeiro: UFRJ, 1997. Literatura de Viagem: características de uma documentação. Notícia Bibliográfica e Histórica, Campinas, SP PUCCamp, v. XIII, n. 104, p. 212-229, 1981.; Luciana de Lima Martins . O Rio de Janeiro dos viajantes. O olhar britânico (1800-1850). Rio de Janeiro: Jorge Zahar, 2001.; Karen Macknow Lisboa. A nova Atlântida de Spix e Martius: natureza e civilização na Viagem pelo Brasil (1817-1820). São Paulo: Hucitec, 1997.;___. Os olhar estrangeiro..., cit.; José Carlos Barreiro. Imaginários e viajantes no Brasil no século XIX: cultura e cotidiano, tradição e resistência. São Paulo: Unesp, 2002.;A. M. M. Belluzzo. O Viajante e a Paisagem Brasileira. Porto Arte (UFRGS), v. 25, p. 41-57, 2008.

Brasil dos viajantes. 2. ed. Rio de Janeiro: Objetiva/Metalivros, 1999.;

A paisagem brasileira através do olhar britânico. In: Carlos Eugênio Marcondes de Moura. (Org.). Brasil: GrãBretanha: uma relação de cinco séculos. São Paulo: Ed. do Autor, 2010, v., p. 96-123. Flora Süssekind. O Brasil não é longe daqui. O narrador, a viagem. São Paulo: Companhia das Letras, 1990.; Mary Louise Pratt. Os olhos do império. Relatos de viagem e transculturação. Trd. Jézio Herman Bonfim. Bauru: Edusp, 1999.; Odilon Nogueira de Matos. A literatura dos viajantes estrangeiros como fonte para nossa história. Separata Memórias da I Semana da História. Franca: Unesp, 1979. Gilberto Freyre . Ingleses no Brasil. Rio de Janeiro: José Olímpio, 1948.; Ângela Domingues. O Brasil nos relatos de viajantes ingleses do século XVIII: produção de discursos sobre o Novo Mundo. Revista Brasileira de História (online). 2008, vol.28, n.55. p. 133-152.; Carlos G. Mota. Europeus no Brasil à época da independência. Um estudo. In: C. G. Mota (org.) 1822: dimensões. São Paulo: Perspectiva, 1972. Amilcar Torrão Filho. A arquitetura da alteridade: a cidade luso-brasileira na literatura de viagem (1783-1845). São Paulo: Hucitec/ Fapesp, 2010.
} 
das experiências pelas quais passaram aqueles que viajavam."38 Portanto, é de se esperar que a variedade de informações veiculadas por meio dos relatos, diários, relatórios de viagem, assim como as múltiplas possibilidades de interpretações dessas informações, estejam circunscritas à outras tantas categorias que lhe dão sentido e que sejam constantemente consequência da diversidade de estudos historiográficos.

Partindo de relatos de viajantes britânicos ${ }^{39}$ e franceses $^{40}$ que parecem representativos de um universo de generalizações sobre o Brasil e os "brasileiros", temse como hipótese nesta pesquisa que o olhar estrangeiro teria facilitado uma visão propositiva em torno de uma identidade "brasileira", a partir de especificidades de seus próprios discursos. Ainda que, muitas vezes, por meio de contradições, esses viajantes tenham exposto suas definições e atribuições de caráter aos habitantes do Brasil, o uso de forma mais ou menos definida do termo "brasileiro" por eles forneceu ao panorama de constituição de uma identidade um aparato externo, munido de interface com a ciência, com a atividade comercial, com a arte, gerando, assim, uma linguagem compatível entre eles com algum poder prático no processo dinâmico e dialético de construção de identidades e alteridades. A literatura de viagem deve "dizer o outro" e, assim, "o mundo que se descreve é sempre uma imagem invertida, como um espelho, que ressalta a diferença do outro a partir da imagem espectral do mesmo" ${ }^{41}$. Desta maneira, o que nos interessa é a situação de alteridade que surge entre, de um lado,

\footnotetext{
${ }^{38}$ Valéria Lima. J.-B. Debret, historiador e pintor: a viagem pitoresca e histórica ao Brasil (1816-1819). Campinas-SP: Editora da Unicamp, 2007. p. 175.

${ }^{39}$ Como menciona Luciana de Lima Martins, palavras que no Aurélio são sinônimas, "britânicos" e "ingleses" têm significados diferentes na língua inglesa. "Na verdade", segundo ela, "dizer que um estudo restringe-se aos viajantes ingleses, na Grã-Bretanha, significa excluir galeses, escoceses e irlandeses. Considerar 'inglês' como 'britânico' é um erro.” L. L. Martins. O Rio de Janeiro dos viajantes..., cit., p. 9. Neste trabalho, com exceção de Thomas O’Neil que é irlandês e de Henry Koster, nascido em Portugal, mas de pais ingleses, todos os demais viajantes britânicos analisados são nascidos na Inglaterra. Os relatos de viajantes britânicos analisados são Maria Graham. Diário de uma viagem ao Brasil e de uma estada neste país durante parte dos anos 1821,1822 e 1823. Trad. e notas de Américo J. Lacombe. São Paulo: Editora Nacional, 1956; Henry Koster. Viagens ao nordeste do Brasil. São Paulo: Nacional, 1942.; John Luccock. Notas sobre o Rio de Janeiro e partes meridionais do Brasil. São Paulo: Martins, 1942; John Mawe. Viagens ao interior do Brasil, principalmente aos distritos do Ouro e dos Diamantes. Trad. De Solena Benevides Vianna. Rio de Janeiro: Zélio Valverde, 1944; Thomas O 'Neil. A vinda da Família Real Portuguesa para o Brasil. Trad. Ruth Sylvia de Miranda Salles. José Olympo: Rio de Janeiro, 2007.

${ }^{40}$ São eles: Jean Baptiste Debret. Viagem pitoresca e histórica ao Brasil.2. v. Trad de Sergio Milliet. São Paulo: Martins. 1949; A. Saint-Hillare. Viagem pelas províncias do Rio de Janeiro e Minas Gerais. Trad. de Clado Ribeiro de Lessa. São Paulo: Companhia Editora Nacional, 1938.; L. F. de Tollenare. Notas dominicais: tomadas durante uma viagem em Portugal e no Brasil em 1816, 1817 e 1818. Bahia: Progresso, 1956. Ferdinand Denis. Brasil. Trad. João Etienne Filho e Malta Lima. Belo Horizonte/São Paulo: Itatiaia/ EDUSP, 1980. Sempre que possível, as primeiras edições nas línguas originais serão consultadas.

${ }^{41}$ A. T. Filho. A arquitetura da alteridade..., cit. p. 55 Ver também . M. L. Pratt. Os olhos do império..., cit.
} 
britânicos e franceses, e de outro, portugueses americanos, exercendo influência sobre a própria autoimagem destes últimos.

Os múltiplos pretextos oferecidos pelo Brasil para a viagem estão explicitados nas impressões de muitos destes indivíduos, como em August de Saint-Hilaire, naturalista francês que esteve no Brasil entre 1816 e 1822, ao expor que "raros são os países que oferecem tantos recursos como o Brasil, e sejam como ele destinados a representar na política papel tão importante." ${ }^{42} \mathrm{O}$ crescente contingente de estrangeiros fascinados pelas potenciais descobertas que viriam a ter sobre uma colônia, até este momento e até certo ponto protegida dos olhares externos, aumentou com tantas transformações políticas, sociais e econômicas vivenciadas pelo Brasil na primeira metade do século $\mathrm{XIX}^{43}$. Os motivos das viagens às terras luso americanas iam muito além, neste momento, da curiosidade circulante no Velho Mundo, onde fantasia e realidade se confundiam e instigavam à exploração do Novo Continente. As condições políticas do começo dos oitocentos abriram ainda mais as portas do Brasil a cientistas, comerciantes e outras tantas profissões, cada uma com sua visão particular e com os aspectos que as interligavam: interesse por um país cuja mudança vivida supostamente traçaria a marcha rumo à civilização. Segundo John Mawe, comerciante e mineralogista inglês que percorreu o interior do país entre 1807 e 1811, "um viajante que se aventura a apresentar suas impressões ao público é, geralmente, encorajado pela convicção de que elas encerram informações novas e interessantes" ${ }^{\prime 4}$, e o Brasil apresentava-se neste início de século como um universo aberto às novidades que os viajantes tanto almejavam, seja para expor suas observações ao público europeu, seja para interesses pessoais e/ou comerciais.

Segundo K. M. Lisboa, a produção intelectual que acompanhou as viagens destes estrangeiros deve ser compreendida dentro do contexto da expansão capitalista do

\footnotetext{
${ }^{42}$ A. Saint-Hillare. Viagem pelas províncias..., cit., p. 13.

${ }^{43}$ A regulamentação do mercado externo e demais medidas que articulassem a economia luso americana apresentaram-se como decisões urgentes e decisivas a serem tomadas pelo governo português, articulando-os ao cenário internacional. Estas medidas teriam o papel de preencher o vazio deixado pelo fim do pacto colonial, aresta fundamental do sistema de dominação vigente entre Portugal e Brasil. Neste cenário, a Grã-Bretanha, potência "protetora" e mediadora das relações comerciais portuguesas, neste momento inacessíveis ao mercado europeu devido ao bloqueio continental, garantiu posição privilegiada nas relações externas com o império português. A assinatura dos tratados de 1810 realocaria o Império português no sistema internacional, garantindo uma importante "conquista" para o governo britânico, aumentando seus lucros e dinamizando a economia do Brasil. Ver: V. Alexandre, Os sentidos do império..., cit.; A. Slemian \& J. G. Pimenta. A corte e o mundo..., cit.

${ }^{44}$ J. Mawe. Viagem ao interior do Brasil..., cit. p. 23.
} 
século XIX. ${ }^{45}$ No entanto, algumas razões práticas, para além das implicações políticas e/ou econômicas que explicam a atração dos estrangeiros pelo Brasil e que contribuíram, de alguma forma, para a ebulição das identidades, também podem elucidar o grande afluxo forasteiro, como a melhora dos meios de transporte e de comunicação. Segundo Lisboa, "em relação ao restante da América, viajar no Brasil era mais seguro devido à relativa estabilidade política e à presença de muitos estrangeiros; igualmente era possível fazer-se uma longa viagem, passando por regiões muito diversas, sem o transtorno de cruzar fronteiras." 46

A diversidade de sentidos conferidos aos termos identitários e a problematização destes vocábulos, além de constituírem um manancial de problemas relevantes para a historiografia, permitem compreender não somente o emprego de termos como "nação", "pátria", "Brasil", "portugueses" e "brasileiros" no período proposto, mas também seu imbricamento com a própria e futura identidade brasileira, dimensão necessária da construção do Estado nacional. Estes aspectos são abordados aqui a partir da visão externa que os viajantes estrangeiros deixaram sobre os habitantes da América portuguesa, exercendo papel na construção da imagem do Brasil como nação.

Neste sentido, os relatos de viagem parecem um universo documental propício para se conduzir a investigação na medida em que os viajantes estrangeiros descreveram o Brasil e os "brasileiros" de modo muito caricato, por alguns, e outros exaltando as suas qualidades, possibilitando a existência de um "outro" e, por sua vez, de um "eu", válida tanto para britânicos e franceses, que não é o tema desta pesquisa, quanto para os habitantes do Brasil. Podemos pensar, então, que a identidade que o estrangeiro imputa ao luso americano está pautada pelo "não ser" inglês ou francês, abrindo a possiblidade do "ser brasileiro". O fundamento básico desta pesquisa está posto, portanto, nos seguintes termos: há uma introdução qualitativa de elementos novos no contexto luso americano abordado pelos viajantes estrangeiros, que produziu movimento dinâmico nos espaços de sociabilidade. Um destes elementos novos é o "brasileiro".

O tema estabelecido delimitou o corpus documental desta pesquisa, relatos de viajantes estrangeiros, especificamente britânicos e franceses que estiveram no Brasil entre os anos de 1808 e 1822, que permitiu a investigação da forma como as expressões

\footnotetext{
${ }^{45}$ K. M. Lisboa. Os olhares..., cit. p. 269.

${ }^{46}$ Ibidem, p. 268.
} 
identitárias, utilizadas por tais viajantes para se referirem aos habitantes da América portuguesa, foram empregadas, levando-se em consideração o momento em que escreveram seus relatos. Isto coloca a análise sobre a formação de uma possível identidade "brasileira" a partir de visões estrangeiras sob perspectiva de situações vivenciadas não apenas no plano das suposições, mas baseada na forma como os acontecimentos sócio-políticos do período foram vistos, constituindo elementos cruciais para a oferta e politização das identidades coletivas apreendidas e delineadas pelos viajantes.

Entre os britânicos analisados e seus relatos estão cinco viajantes: Thomas O'neil, conde irlandês que serviu como primeiro-tenente dos fuzileiros a bordo do London, nau do almirante-de-esquerda Sidney Smith, a quem coube a escolta da Família Real portuguesa ao Brasil. O relato da viagem da Corte portuguesa até sua nova residência foi publicado em 1810 e é documento histórico raro, apenas recentemente publicado no Brasil sob o título A vinda da família real portuguesa para o Brasil ${ }^{47}$; John Mawe, mineralogista inglês nascido em Derbyshire que esteve no Brasil entre os anos de 1807 e 1811 visando estabelecer relações comerciais. Publicou diversas obras sobre mineralogia e geologia, entre elas o seu principal trabalho, Viagem ao interior do Brasil. Publicado o relato pela primeira vez em 1812 em Londres, a obra despertou grande interesse na Europa, laçada nove anos depois a segunda edição inglesa e entre a primeira e segunda edição, duas tiragens nos Estados Unidos, e traduções para o francês, italiano, holandês, sueco, alemão, russo e português ${ }^{48}$; John Theodore Koster, conhecido como Henry Koster, filho de comerciante inglês de Liverpool, que chegou ao Brasil em 1809, tornando-se senhor de engenho no nordeste do país, com uma pequena interrupção de 1815 a 1817, período em que esteve em Londres e onde publicou em

\footnotetext{
${ }^{47}$ A edição publicada no Brasil foi traduzida a partir do exemplar do bibliófilo José Mindlin, concedido à Comissão do Bicentenário, criada no Rio de Janeiro. T. O 'Neil. A vinda da Família Real Portuguesa...., cit. $\mathrm{O}$ título original constitui elemento raro, tendo sido distribuído à época de sua primeira edição apenas para alguns subescritores da obra. Idem. A concise and accurate account of the proccedings of the Squadron under the command of Rear Admiral Sir Sydney Smith.... Londres: Barfield, 1810.

${ }^{48}$ A primeira tradução para o português data de 1819, com o título: "Viagens ao interior do Brasil, com uma exata descrição da ilha dos açores, por John Mawe, Inglez. Authorizadas pelo Rei fidelíssimo D. João VI, Nosso Senhor, a beneficio da livraria do convento de S. Francisco da Cidade, obra promovida pelo R. P. M.. Fr. Polidoro de N. S. da Lapa, leitor de Theologia e bibliotecário da mesma. Lisboa: Na Imprensa Régia, Anno 1819. Com licença.” A edição em língua portuguesa de 1922 está baseada na tradução francesa de Eyriès, feita por Dermeval Lessa, "Viagens ao interior do Brasil, particularmente aos distritos do ouro e do diamante, em 1809-1810, por John Mawe, vertido, para o vernáculo, da tradução francesa de J. B. B. Eyriés, por Dermeval Lessa. Belo Horizonte: Imprensa Oficial, 1922.”; A edição Itatiaia e Edusp se insere na "Coleção Reconquista do Brasil" e está baseada na edição de 1944, Viagem ao interior do Brasil, principalmente aos distritos de ouro e dos diamantes, publicada no Rio de Janeiro pela Zélio Valverde. J. Mawe. Viagem ao interior do Brasil..., cit.
} 
1816 relato de sua estadia no país, traduzida como Viagens ao nordeste do Brasil ${ }^{49}$; John Luccock, comerciante inglês de Yorkshire que chegou ao Brasil em 1808 e onde permaneceu por dez anos, publicando em 1820 o relato desta estadia ${ }^{50}$, traduzido para o português em 1942 sob o titulo Notas sobre o Rio de Janeiro e partes meridionais do Brasil; Maria Graham, escritora, desenhista e preceptora da Família Real portuguesa, filha e esposa de grandes exploradores, desde cedo esteve inserida no mundo das viagens. Permaneceu no país durante parte dos anos 1821, 1822 e 1823 e publicou seu relato em 1824 na Inglaterra, tendo sua primeira edição traduzida para o português sob o título Diário de uma viagem ao Brasil e de uma estada nesse país durante parte dos anos 1821,1822 e $1823 .^{51}$

Entre os franceses, está o comerciante e industrial Louis François de Tollenare, natural de Nantes, que chegou ao Recife em 1816 e depois à Bahia em 1817 com o objetivo de buscar novos fornecedores de algodão, retornando para França em 1818. Segundo Oliveira Viana no prefácio da edição de 1956, o viajante foi homem de “espírito intelectual e observador infatigável”, habituado a consignar aos domingos tudo o que via digno de notícia, com um fraco pelas dissertações morais e gosto literário de sua época, organizando volume a que deu o título de Notas Dominicais ${ }^{52}$; Jean Baptiste Debret, parisiense primogênito de um funcionário do parlamento francês, que ingressou aos 47 anos na expedição de artistas franceses organizadas por Joachim Lebreton rumo ao Brasil, conhecida como "Missão artística de 1816", onde permaneceu até 1831. A partir das atividades desenvolvidas e dos documentos relativos à expedição, publicou e Viagem pitoresca e histórica ao Brasil. ${ }^{53}$; August de Saint-Hilaire, naturalista, filho da

\footnotetext{
${ }^{49}$ H. Koster. Travels in Brazil, by Henry Koster. Londres : Longman, 1816. A obra teve várias edições publicadas em diversas línguas, sendo a primeira edição brasileira Viagens ao nordeste do Brasil. são Paulo: Nacional, 1942.

${ }^{50}$ J. Luccock. Notes on Rio de Janeiro and the southern parts of Brasil taken during e residence of ten years in that country from 1808 to 1818, by John Luccock. Londres : Samuel Leight, MDCCCXX, 1820. Existem duas traduções para o alemão, a primeira integral de 1821, a segunda compilada, de 1831. J. Luccock. Notas sobre o Rio de Janeiro..., cit.

${ }^{51}$ M. Graham. Diário de uma viagem ao Brasil..., cit. Tradução reeditada em 1990. Obra original publicada na Inglaterra: Journey of a voyage to Brazil and residence there during parto f the years 1821, 1822 e 1823. Londres: Longman, 1824

${ }^{52}$ L. F. de Tollenare. Notes dominicales prises pendant um Voyage em Portugal et au Brésil. Ed. et com commentaires Léon Bourdon. Paris, Presses Universitaires de France, 1971-1973. 3v. Da edição em francês, foram consultados os volumes referentes ao Brasil, suprimido o volume da viagem a Portugal. As partes referentes aos estados de Pernambuco e da Bahia foram traduzidas por Alfredo de Carvalho e publicadas sob o título de Notas dominicais, no volume 61 da Revista do Instituto Arqueológico e Geográfico Pernambucano, em 1904 , e no volume 14 da revista do Instituto Histórico e Geográfico da Bahia, em 1907, respectivamente. A edição em português consultada na pesquisa é o Notas dominicais..., cit.

${ }^{53}$ Publicada em Paris entre 1834 e 1839, a obra é composta por 156 pranchas que ilustram cenas do cotidiano do Brasil, sendo o primeiro tomo datado de 1834, o segundo de 1835 e o último de 1839 . J. B.
} 
nobreza do interior francês, chegou ao Brasil em 1816, embarcado na comitiva do conde de Luxemburgo enviada para solucionar problemas de fronteira da Guiana Francesa com o governo de D. João, permanecendo até 1822. Neste período, visitou as províncias do centro e centro-sul do país e dentre os diversos relatos produzidos pelo viajante, analisamos Viagem pelas províncias do Rio de Janeiro e Minas Gerais, publicada pela primeira vez em $1830^{54}$; por último, Ferdinand Denis, historiador, bibliotecário e escritor parisiense, que ingressou em viagem pela América do Sul em 1816, desembarcando em Salvador onde prestou serviços ao embaixador francês, permanecendo no Brasil até 1821. Publicou, entre tantas outras obras, Brasil, em $1837^{55}$, depois do sucesso das obras de Debret e Rugendas, considerado especialista em estudos sobre o Brasil na França.

Percebe-se que o universo dos viajantes era composto por uma variedade de profissionais e seus motivos específicos de viajar, que conferia a estes grupos heterogêneos uma enormidade de possibilidades e consequentemente de observações sobre a viagem, refletidas nos diversos relatos existentes, principalmente os relativos ao Brasil das primeiras décadas do século XIX. Esta variedade de narrativas, ainda que circunscrita dentro de especificidades de cada viajante, remete a um interesse comum em falar sobre o Brasil e os "brasileiros", permitindo a afirmação da existência de um comportamento mais ou menos comum entre os viajantes. Ao investigar relatos de viajantes com origens e formações tão variadas, mas representativas de um universo de generalizações, não buscamos discursos específicos sobre o "brasileiro", mas consideramos as especificidades dos discursos sobre ele para chegar a um diagnóstico: o de que o olhar estrangeiro facilitou uma generalização propositiva em torno de uma identidade brasileira. Assim, o que se buscou foi a investigação de como as expressões alusivas às identidades coletivas - "brasileiro", "português" e suas variáveis - eram referidas pelos viajantes, tanto nas obras originais, quanto nas primeiras edições em português, quando possível, com o objetivo de observar a oferta de identidades para os habitantes do Brasil e a configuração de uma expressão identitária totalizadora,

Debret. Voyage Pittoresque et Historique au Brésil, ou séjour d'um Artiste Français au Brésil, Depuis 1816 junsqu'em 1831 inclusivement, Époques de l'Avénement et de l' abdication de S.M.D. Pedro I, Foundateur de 1'Empire Brésilien. Paris: Firmen Didot Frèses, 1834-1839, 3 vv. A edição em português consultada foi a Viagem pitoresca e histórica ao Brasil..., cit.

${ }^{54}$ A. Saint-Hilaire Voyage dans les provinces de Rio de Janeiro et de Minas Gerais, Paris, Grimbert et dorez, 1830. A edição em português consultada foi Viagem pelas províncias do Rio de Janeiro e Minas Geraes..., cit.

${ }^{55}$ F. Denis. Brasil...., cit. Na língua original: Brésil, par M. Ferdinand Denis; Colombie et Guyanes, Par M. C. Famin. Paris, Firmin Didot frères, éditeurs, MDCCCXXXVII. 
centralizada no "brasileiro". Ainda que a apropriação dos discursos dos viajantes pelo processo de construção de identidades não tenha sido imediata ao momento do qual trata a pesquisa, ou seja, quando os escritos dos viajantes permaneceram inéditos, podemos falar da interação desses registros no universo simbólico e discursivo do observador. Neste, as expressões identitárias puderam surgir e ser transmitidas de diversos modos, direta ou indiretamente, de forma escrita ou falada, ao passo que alguns significados acabavam sendo absorvidos pelos habitantes em reflexões e definições sobre si mesmos.

A pesquisa tocou em algumas frentes, ora situada em discussões da literatura de viagem como fonte e as formas de retórica e linguagem empreendidas, ora se submetendo às especificidades do Brasil dentro do debate da questão nacional e seus desdobramentos. Do ponto de vista das fontes, o que se buscou estabelecer foram as construções de identidades coletivas no recorte cronológico estabelecido, baseado na abertura de possibilidades de viagem a indivíduos de outras nações a partir de 1808, até o momento da mudança de estatuto político do Brasil entre as demais nações do mundo com a independência política, em 1822.

O primeiro capítulo, "Os viajantes estrangeiros e o Brasil das primeiras décadas do século XIX" trata, na primeira parte, das formas e métodos da literatura de viagem empregados por seus autores ao longo do século XVIII, com o objetivo de investigar as (des)continuidades de tradição que já haviam sido marcadas no período anterior à produção dos viajantes das primeiras décadas do século XIX, recuperando a importância das linguagens em que os textos foram produzidos; adiante, a discussão está em torno da concepção de alteridade e dos elementos socioculturais dos viajantes que permitiram a eles não só reforçar sua própria identidade, como também - este é o tema da segunda parte - criar juízos a respeito dos habitantes do Brasil, permitindo uma imagem por oposição com alguma capacidade de ressignificação e disponibilizando uma forma de construção identitária.

O segundo capítulo, "Brasil e brasileiros: identidades coletivas no discurso dos viajantes", analisa, na primeira parte, a forma como os viajantes descreveram e interpretaram os episódios políticos do início do século XIX como detonadores de sentimentos e interesses comuns entre "brasileiros", e os modos pelos quais tais viajantes construíram imagens sobre o Brasil, escrevendo sobre uma possível formação nacional brasileira; a segunda parte analisa como os viajantes britânicos e franceses definiram a sociedade luso americana, salientando tipos específicos de identidades e a 
articulação destas em classes sociais, fazendo referência também às exclusões de classes quanto à diferenciação entre aqueles que deveriam ser considerados "brasileiros", daqueles que deveriam ser excluídos desse processo de definição de uma identidade totalizadora a determinar a configuração de uma futura identidade nacional.

O trabalho com a documentação esteve pautado pela busca e análise das descrições e expressões utilizadas para denominar e classificar os habitantes da América portuguesa, recorrendo aos textos traduzidos para o português nas primeiras edições, e às equivalências dos termos nas obras na língua original apenas quando se tratasse de expressões diretamente relacionadas às identidades coletivas. 


\section{Capítulo I - Os viajantes estrangeiros e o Brasil das primeiras décadas do século XIX}

\subsection{A literatura de viagem e os viajantes oitocentistas.}

As formas e métodos da literatura de viagem empregados por seus escritores ao longo do tempo condensaram características que impõem, como um dos grandes desafios à historiografia no uso deste gênero literário como fonte, reconhecê-lo como tal e atentar para o fato de que obedece a determinados parâmetros e expectativas ${ }^{56}$, além das condições de produção em que circulava. A literatura de viagem foi e continua sendo transformada ao longo do tempo, de acordo com as imposições do gênero e demandas em torno dela, mas ainda assim permeada de continuidades que tornam os relatos de viagem objeto de considerável complexidade. Compreendendo o meio pelo qual os conceitos encontrados nesse tipo de produção textual são expressos, de acordo com as convenções imposta à literatura de viagem, o historiador tem menos chances, como sugere Torrão Filho, de confundir mudanças nas formas retóricas de expressar conceitos com mudanças de ideias. ${ }^{57}$ Neste sentido, é importante analisar algumas das mudanças e continuidades pelas quais passou a literatura de viagem, principalmente as diversificações sentidas no gênero ao longo do século XVIII para o XIX, quando as narrativas produzidas por viajantes a serviço da ciência ganharam perspectivas que iam além de interesses estritamente científicos, e estavam de modo geral inseridos num quadro de preocupações econômicas, políticas e artísticas.

Alguns aspectos dos relatos de viagem escritos nas primeiras décadas do século XIX sugerem especificidades que os colocam enquanto inauguradores da exploração e redescobrimento do Brasil, no sentido de terem sido esses viajantes os que de maneira mais intensa empreenderam projetos na América do Sul, principalmente a portuguesa, antes relativamente fechada à presença externa. Atentamos para o fato de que, assim como os relatos de viagem de outras épocas, os oitocentos imprimiram traços aos textos produzidos pelos viajantes que, não obstante suas peculiaridades de acordo com a profissão, intenção, financiamentos e tantos outros aspectos de que são portadores, são

\footnotetext{
${ }^{56}$ Amilcar Torrão Filho. A arquitetura da alteridade: a cidade luso-brasileira na literatura de viagem (1783-1845). São Paulo: Hucitec/ Fapesp, 2010.p. 23.

${ }^{57}$ Ibidem, p. 23.
} 
herdeiros de outras formas de relato, de outros períodos, somados às suas próprias particularidades.

Embora o ano de chegada da Família Real ao Brasil seja incontestavelmente considerado pela historiografia como marco das grandes transformações ocorridas aqui, alguns autores contemporâneos afirmam de forma categórica que uma certa descoberta científica do Brasil se deu, após 1808, por europeus "esclarecidos, lúcidos, dinâmicos e inovadores, detentores de interesses científicos, comerciais e econômicos notórios em relação aos domínios coloniais europeus", homens que deram início ao reconhecimento científico sistemático da colônia luso portuguesa. ${ }^{58}$ De acordo com Ângela Domingues, apesar da inegável importância de 1808 para a produção de conhecimento científico, tendo como alvo de curiosidade principal privilegiado pelos europeus o continente americano, importa reconhecer também que ao longo do século XVIII houve grande esforço de grupos sociais a serviço da ciência e dos estados europeus na obtenção de informações sobre as porções americanas dos impérios europeus. ${ }^{59} \mathrm{O}$ "novo descobrimento" de que trata Sergio Buarque de Holanda, por exemplo, ao se referir aos indivíduos de "língua travada" que adentraram o Brasil nesta época teria ocorrido pelo atraso científico ao qual o país estava submetido até as medidas de D. João e as incursões de "povos mais adiantados" numa terra em que "a pesquisa era alvo de atenção". ${ }^{60}$ Mas, ao contrário do que o autor postulava sobre o Brasil ter permanecido desconhecido, ele próprio mencionava estrangeiros que escreveram sobre o Brasil antes da vinda da corte, como o próprio Pero Vaz de Caminha, cronista da frota de Cabral, a presença de missionários franceses, do alemão Hans Staden, que em 1557 descreve o litoral de São Vicente, entre muitos outros. O "redescobrimento" do Brasil pelos viajantes do século XIX esteve pautado mais pela mudança da viagem, que até 1808 constituía basicamente viagens de circunavegação, atreladas às margens (além de viagens feitas para o comércio de escravos no Atlântico) e, a partir de 1808, dando início à interiorização das viagens, do que pelo interesse em se desvendar o Brasil, já aguçado anteriormente. Outro aspecto desse novo descobrimento foi o mercado editorial, menos explosivo no século XVIII do que foi no XIX e essencial para se pensar

\footnotetext{
${ }^{58}$ Ângela Domingues. O Brasil nos relatos de viajantes ingleses do século XVIII: produção de discursos sobre o Novo Mundo. Revista Brasileira de História (online). 2008, vol.28, n.55. p. 134.

${ }^{59}$ Idem. Notícias do Brasil Colonial: a imprensa cientifica e política a serviço das elites (Portugal, Brasil e Inglaterra). Varia História (online). 2006, vol. 22, , 35, p. 151.

${ }_{60}$ Sergio Buarque Holanda. (org.). História Geral da Civilização Brasileira. A Época Colonial. Administração, Economia, Sociedade. Rio de Janeiro: Bertrand Brasil, 1997. v.2, t. I. p. 161.
} 
a circulação dos relatos, que contavam, para se propagarem, com auxílio significativo de casas editoriais e livreiros. ${ }^{61}$

Não obstante a importância da presença de estrangeiros no Brasil no início dos oitocentos, que passaram a visitar regiões antes fechadas aos olhares de fora, estando aí "um dos fatores do vivo interesse que, ainda em nossos dias podem suscitar os escritos e quadro de viajantes chegados do velho mundo entre o ano da vinda da corte e pelo menos, o do advento da Independência," 62 o século XVIII proporcionou condições para a produção de uma literatura de viagem influenciadora de viajantes posteriores. A este respeito, Maria Fernanda Bicalho escreve que

É impossível, em se falando da Europa naquele período, deixarmos de mencionar todo o clima cultural e ideológico que envolveu a Época das Luzes, o desenvolvimento da ciência e da razão, a curiosidade pelos fenômenos da natureza, a consciência planetária e um certo olhar voltado para o exótico e o selvagem, que aguçou a curiosidade de cientistas e filósofos a respeito das sociedades não-europeias, sobretudo aquelas ainda pouco conhecidas ou contatadas pelos navegadores abrindo caminho para o que poderíamos chamar de uma 'proto-etnologia'. A esse movimento propriamente intelectual, soma-se o interesse das potências na exploração de mares e territórios ainda pouco conhecidos, dando origem às viagens de circunavegação, visando à descoberta e à exploração de novas possibilidades expansionistas e colonizadoras. ${ }^{63}$

Uma produção textual passou a ser difundida a partir desta visão intelectualizada do iluminismo, pautada por uma nova metodologia da ciência, a partir da qual os viajantes saem dos gabinetes, dando margens para o aumento da curiosidade e do imaginário europeu em relação ao Brasil. ${ }^{64}$ Isto nos permite pensar britânicos e

\footnotetext{
${ }^{61}$ Jean Marcel Carvalho França. A construção do Brasil na literatura de viagem dos séculos XVI, XVII e XVIII. Antologia de textos. 1591-1808. Rio de Janeiro: José Olympo; São Paulo: Unesp, 2012. p. 24.

${ }^{61}$ Ibidem, p. 79.

${ }^{62}$ S. B. Holanda. (org.). História Geral da Civilizaçãoo.., cit, p. 13.

${ }^{63}$ Maria Fernanda Bicalho. A cidade e o império. O Rio de Janeiro no século XVIII. Rio de Janeiro: Civilização Brasileira, 2003. p.105.

${ }^{64}$ "A nova ética das Luzes, segundo a qual os homens poderiam aspirar à liberdade e à realização de sua felicidade na terra, dera um vigoroso impulso ao estudo das ciências. Os homens, como lembra Carl Becker em seu livro sobre a cidade divina do século XVIII, passaram a tentar edificar o paraíso celeste no mundo de todo dia, aliando ao seu otimismo utópico a mentalidade pragmática das reformas concretas. Daí o renascimento cientifico de meados do século XVIII, principalmente no campo das ciências naturais
} 
franceses no contexto neocolonialista, nova modalidade de exploração das potências europeias, que buscava ampliação de mercados e intervenção política nas regiões exploradas. Ao passo que os domínios luso americanos tornavam-se um dos principais alvos dos olhares europeus, as disputas e rivalidades entre os países, como França e Grã-Bretanha, agudizavam-se, fosse por abertura e disputa por novas rotas, por estabelecimentos de novas fontes de relações político-econômicas ou, de um modo geral, por disputa de influências em territórios que significavam grande potencial econômico no quadro mundial dos Estados europeus. E nesse contexto, os relatos tornavam-se os próprios agentes/sujeitos deste campo de disputas, constituindo um elemento a mais na dinâmica entre Estados no que se refere ao estabelecimento do poder. As narrativas deram, portanto, aos países que enveredavam nas viagens ultramarinas, um aporte ideológico, político e econômico na sustentação dos objetivos expansionistas, incentivando, assim, tais viagens.

Os meados do século XVIII foram o momento de uma nova tomada de consciência planetária ${ }^{65}$, diferenciada daquela experimentada por meio das navegações que culminaram nos primeiros contatos com a América, exigindo da mentalidade europeia uma nova visão de mundo ${ }^{66}$, que coincidiu com várias outras mudanças, como a emergência de formas burguesas de subjetividade e poder, acompanhada por uma etapa territorial do sistema capitalista que buscava matérias-primas, além de empurrar o comércio costeiro para o interior, marcando, assim, objetivos intimamente relacionados ao aumento e manutenção do poder estatal. Neste sentido, a argumentação geralmente usada na defesa de que foi somente no século XIX que o Brasil abriu, finalmente, as

\footnotetext{
e mecânicas, a exaltação do sábio e do cientista como o homem prático e de ação: caberia a eles construir a felicidade dos homens com inventos e descobertas úteis ao bem estar e à saúde e ao proveito da sociedade." Maria Odila Leite da Silva Dias. Aspectos da ilustração no Brasil In: A interiorização da metrópole e outros estudos. 2ed. São Paulo: Alameda, 2009.

${ }^{65}$ Foi vagaroso o processo de tomada de consciência da existência de um mundo constituinte não somente de três partes universais, Ásia, África e Europa, mas também do continente americano., mencionado timidamente nos relatos de viagem do século XVI. Segundo Jean Marcel Carvalho França, "desde muito cedo, contar em detalhes o que tinha visto ao longo de sua navegação - oralmente ou por escrito - tornouse para gente do mar desses lugares quase um dever de ofício" e deu origem à produção de relatos de viagem que promoveu, lenta mas progressivamente, o imaginário europeu com relação à América. Para que a Europa desse os contornos de América às terras "descobertas", não obstante o peso e importância do "testemunho de marinheiros, o empenho de cartógrafos, a ansiedade de governantes e comerciantes e a curiosidade dos letrados [...] para a grande maioria dos habitantes do Velho Mundo, foi necessário esperar mais de cem anos, esperar que se consolidassem as experiências colonizadoras de portugueses e espanhóis [...]”.J. M. C. França. A construção do Brasil..., cit. p. 24-31.

${ }^{66}$ Visão esta permeada por dois processos simultâneos, "a emergência da história natural como uma estrutura de conhecimento e o impulso à exploração continental, por oposição à marítima, interagentes em si." Mary Louise Pratt. Os olhos do império: relatos de viagem e transculturação. Trad. Jézio Hernani Bonfim Gutierre. Bauru: EDUSC, 1999. p. 35.
} 
portas ao contato com outros países, seja para fins político-econômicos ou científicos ${ }^{67}$, é desfavorável a uma análise mais adequada das relações estabelecidas entre o governo português e outras nações no período anterior ao estabelecimento do centro de poder no Rio de Janeiro, e negligencia a existência de estratégias políticas por parte da coroa portuguesa que se favorecia nas trocas e acordos estabelecidos com outros países. Ângela Domingues, por exemplo, atenta para o fato de que subjacentes aos limites impostos pela coroa de Portugal, e também da Espanha, na circulação de informações sobre suas colônias, também estavam presentes motivos políticos, como a preservação de informações para se obter vantagens econômicas ligadas ao comércio exclusivo ou preferencial de determinado produto, ou ainda, em troca de segurança devido à debilidade militar de Portugal. ${ }^{68}$ Além deste aspecto mais estritamente político, mencionado pela autora, o reabastecimento dos navios nos portos do Brasil, com destinos variados, também é considerado um indício a mais da presença eloquente de estrangeiros no Brasil antes de 1808, principalmente no Rio de Janeiro que não fugiu à regra quanto à curiosidade por parte de cientistas, filósofos, comerciantes, oriundos do Velho Mundo e sedentos de investigação e descobertas pautadas pelas Luzes. ${ }^{69}$

A inevitabilidade da presença de estrangeiros na costa do Brasil não era algo desconhecido pelo governo português; ao contrário, estes tiravam proveito política e economicamente desta situação, estabelecendo relações comerciais com os países aliados que mandavam seus navios aos portos do país. ${ }^{70}$ Estes são dados importantes da presença de estrangeiros no Brasil antes da vinda do Príncipe Regente e a consequente abertura dos portos. Se escrever o que se via durante a viagem era atividade comum e mesmo "obrigatória" para a gente do mar, podemos inferir que, mesmo diante das dificuldades de acesso à colônia portuguesa, os viajantes que estiveram no litoral do

\footnotetext{
${ }^{67}$ Para Martins, por exemplo, "foi na virada do século XIX que o olhar ocidental para a natureza começou a profissionalizar-se, almejando a legitimidade e precisão científicas, e, ao mesmo tempo, proporcionou deleite, alimentando a curiosidade europeia por cenas exóticas" Luciana Lima Martins. O Rio de Janeiro dos viajantes. O olhar britânico (1800-1850). Rio de Janeiro: Jorge Zahar, 2001. p.9.

${ }^{68}$ A. Domingues. O Brasil nos relatos de viajantes..., cit. p.142.

${ }^{69}$ M. F. Bicalho. A cidade e o império..., cit. p. 108-109. Segundo a autora, o Rio de Janeiro era uma cidade "amplamente visitada por europeus de todo o tipo - fossem eles cientistas, filósofos, comerciantes, militares ou contrabandistas -, a documentação acerca daquelas arribadas é testemunho rico e precioso da enorme quantidade de informações, relatos e detalhes que circulavam na Europa sobre a situação da cidade, suas condições e estratégias de defesa, além de descrições sobre a riqueza e efervescência de seu porto. A frequência das arribadas estrangeiras nas praças coloniais do Brasil e a ampla circulação de informações sobre elas contradiziam a cautela e o cuidado metropolitanos em torno do segredo e da clausura de seus portos ultramarinos, desmistificando a ideia de exclusividade do desembarque, do conhecimento e ate mesmo dos negócios dos súditos portugueses naquelas paragens." .

${ }^{70}$ A. Domingues. O Brasil nos relatos de viagem...,cit. p. 142.
} 
Brasil, inevitavelmente devem ter formulado suas ideias acerca do local por onde passaram, tenham estas sido convertidas ou não em relatos sobre o local visitado.

Além destas estratégias político-econômicas, estudiosos luso americanos de finais do século XVIII estavam também imbuídos do estado de espírito das Luzes, procurando serem úteis principalmente com relação à agricultura e voltando seus estudos para esta área. A característica pragmática do português, somada a vários fatores desde os tempos de Pombal, resultou numa política de Estado bem determinada que culminou na identificação de estudiosos no Brasil com interesses materiais da classe rural, características também marcantes no período joanino, resultando desta política, segundo Maia Odila Leite da Silva, memórias e experiências práticas de comerciantes e lavradores "ilustrados". Inicialmente, memórias de cunho estritamente técnico, como a de Manuel Luiz Vieira, endereçada ao Marques de Lavradio, em 1770, intitulada "Ideias da constituição e estudo da fábrica de descascar arroz”; estes métodos também foram perpetrados por estrangeiros, que resultaram, segundo Silva, em memórias e experiências práticas de comerciantes e agricultores. ${ }^{71}$ Ao assinalar a política de incentivo e o aproveitamento dos bacharéis pela Coroa portuguesa, a autora aponta para a acumulação de uma literatura de viagem por estes indivíduos, integrada curiosamente no espírito que se desenvolvia no resto do mundo. ${ }^{72}$ Portanto, direta ou indiretamente, a literatura de viagem, assim como a presença de estrangeiros, relacionada à produção textual das viagens ou à residência efetiva destes, antes da vinda da Corte, exerceu influência significativa na vida e política da Europa em geral, com reflexos também na colônia portuguesa.

Tais informações sobre a América foram propagadas, portanto, em grande parte, por meio dos relatos de viagem, ao ponto de nenhum gênero artístico ou cultural passar totalmente imune ao continente, aumentando a produção de informações a respeito dele que, apesar do limitado número de leitores que tinham acesso a estes elementos, indicava razoável contorno sobre o Novo Mundo construído por esses indivíduos. ${ }^{73}$ Assim, a partir do século XVI, e progressivamente ao longo do tempo, com descrições mais detalhadas, as notícias do mundo corriam a Europa e a gente do mar oferecia uma fonte de informações que tanto aguçavam a curiosidade por lugares desconhecidos, principalmente pela América.

\footnotetext{
${ }^{71}$ M. O. Dias. Aspectos da ilustração no Brasil..., cit. p. 45-51.

72 Ibidem, p. 70.

${ }^{73}$ J. M. C. França. A construção do Brasil..., cit. p. 40.
} 
A observação direta, especificamente para os homens do Iluminismo, constituía um dos aspectos fundamentais para sustentar o sentimento de credibilidade que a ciência exigia. Neste aspecto, ao longo do século XVIII a viagem tornou-se uma ferramenta de veracidade que legava aos que se aventuravam em longas e perigosas expedições o papel de transmitir a seus conterrâneos o que viam. A América portuguesa, como vem sendo dito, apesar de restrições impostas à presença de estrangeiros $^{74}$, não constituía exceção nos objetivos de observação direta que movia as aspirações dos homens de Luzes, que fixaram entre os viajantes europeus padrões descritivos e lugares a serem visitados. Como observa Carvalho França, os homens cultos resolveram sair de seus gabinetes com o objetivo de ver com os próprios olhos e, a partir de então, descrever a diversidade do mundo para seus compatriotas. O próprio Bougainville, oficial, navegador e escritor francês, que recebeu de Luiz XV a missão de navegar ao redor do mundo, a quem França chama de "um desses homens cultos", atentos à importância do conhecimento na formação do pensamento da sociedade europeia e o papel dos relatos de viagem neste processo, descrevia-se como

"viajante e marinheiro, quer dizer, um mentiroso e um imbecil aos olhos daquela classe de escritores preguiçosos e arrogantes que, na sombra de seus gabinetes, filosofam a perder de vista sobre o mundo e seus habitantes, submetendo imperiosamente a natureza às suas imaginações. Procedimento bem curioso e inaceitável este, sobretudo vindo da parte de gente que, nada tendo observado por si própria, somente pode escrever e dogmatizar a partir das observações dos viajantes, aos quais negam as faculdades de ver e de pensar." 75

Com o aperfeiçoamento da ciência, ou seja, o desenvolvimento de novas formas de investigação da natureza, os viajantes passaram a constituir uma sorte de classe formada por homens com métodos de observação e objetivos mesclados, mas com o interesse comum de relatar o que viam com um grau de aprimoramento maior com relação aos textos produzidos até então. "A bem da verdade", comenta França,

\footnotetext{
${ }^{74}$ Até 1808 , a Coroa portuguesa tentou inibir a presença de estrangeiros no território colonial, tendo como uma das primeiras medidas uma lei sancionada em 1591, proibindo nos portos a presença de navios estrangeiros, e impedindo definitivamente quatorze anos mais tarde a presença estrangeira no Brasil. A 8 de fevereiro de 1711, Portugal aprovou a lei que vetava ao Brasil qualquer espécie de comércio com os estrangeiros. M. F. Bicalho. A Cidade e o Império..., cit.

${ }^{75}$ J. M. C. França. A construção do Brasil ..., cit. p. 58.
} 
“ingleses, holandeses, franceses e alemães foram os grandes editores e consumidores da literatura de viagem que circulou pela Europa ao longo dos séculos XVII e XVIII - no século XVI, espanhóis e italianos ainda tinham uma palavra a dizer sobre o processo", salientando que isso "nem de longe significa que o gosto pelas narrativas de viagem e a possibilidade de ter acesso a elas estivessem restritos a tais países"; pelo contrário, espalhava-se um pouco por toda a Europa as notícias de lugares desconhecidos e o apreço por tais informações. $^{76}$

Portanto, seria errôneo considerar categoricamente o século XIX como o momento definidor de uma América que inauguraria descobertas e informações inéditas. Com isso, não estamos tentando destituir a importância do ano de 1808 para as viagens realizadas, devido à nova conjuntura política do império português; porém, há de ser levada em consideração a herança que os séculos anteriores legaram à literatura de viagem, e como isto influenciou os viajantes oitocentistas a escreverem sobre o Brasil, marcando menos uma ruptura do que certa hereditariedade na literatura de viagem, salvo as especificidades de cada período em que o gênero foi produzido. $O$ contexto político aberto em 1808 incentivou uma leitura tendencialmente inovadora de discursos relativos ao Brasil que se refletiram também nas narrativas de viagem, por meio das quais as descrições dos locais visitados e seus costumes acabaram por condensar características dos habitantes do Brasil e instigar a utilização de uma profusão de expressões identitárias que fizessem a eles referência.

O Brasil recebeu, assim, a visita e, em muitos casos, a residência de muitos viajantes europeus a partir do começo do século XIX, dentre eles, britânicos principalmente, devido à influência central que a Grã-Bretanha passaria a exercer sobre o império português. Apesar da presença maciça de britânicos, também estiveram no Brasil a partir dos oitocentos os franceses, além de viajantes de língua alemã, americanos e, em número mais reduzido, viajantes russos, dinamarqueses, suecos, belgas e italianos, oriundos do processo de industrialização que levou diversos grupos nacionais a se expandirem através do comércio e abertura de novos mercados. ${ }^{77}$ Os

\footnotetext{
${ }^{76}$ Ibidem, p. 79.

${ }^{77}$ Observa-se neste período, "a existência de dois grupos distintos representados por momentos políticoexpansionistas diferentes: Inglaterra, Franca e, em menor escala, Rússia e os EUA estariam interessados na 'exploração imediata', por notórios interesses comerciais manifestados por uma burguesia em franco fortalecimento. Já a Alemanha, Áustria, a Suécia e a Itália -que estavam para se firmar como nações unificadas - ainda não estariam participando ostensivamente da corrida expansionista, ou seja, seu lugar no processo de internacionalização do Brasil era mais periférico, em decorrência do seu próprio status no continente europeu." Karen Macknow Lisboa. "Os olhares estrangeiros sobre o Brasil do século XIX". In: Carlos Guilherme Mota. Viagens incompletas: a experiência Brasileira (1500-2000). A grande
} 
textos produzidos por eles, inseridos na trama dos sistemas de poder europeus obstinados pelo aumento de influência e poder político-econômico na América do Sul, estavam voltados, portanto, também à análise das potencialidades econômicas do país, e tinham nos recursos naturais do Brasil um grande componente de estudo para ampliação e manutenção de mercados rentáveis para seus Estados de origem.

A busca por recursos lucrativos era, portanto, um dos atributos dos viajantes oitocentistas que combinava características particulares a traços gerais da narrativa de viagem enquanto gênero literário. Como observou M. L. Pratt, as motivações dos viajantes oitocentistas apontadas por Noe Jitrik é bastante clara, de forma a nos dar visão clara dos atributos relacionados àqueles:

"Eles eram instigados a nos visitar movidos por uma poderosa curiosidade mercantil, instrumentos, por vezes involuntários..., da incansável expansão econômica europeia que, desde o fim do século XVIII, e mesmo antes disso, combinava conhecimento com implementação, interesse científico com necessidade de dominação concreta e humanismo com produção de mercados." 78

Pensando no contexto das monarquias ilustradas na segunda metade do século XVIII - no caso da coroa portuguesa, a presença de Pombal na administração colonial representou tal influência do iluminismo na administração do Estado - as preocupações em modernizar a administração eram colocadas em prática com vistas a racionalizar a gestão do império e buscar melhor posicionamento no sistema de competição interestatal da época, acarretando o fortalecimento político e militar, o melhor aproveitamento dos potenciais coloniais e, claro, o aumento dos lucros. No continente americano, viajantes imbuídos do espírito iluminista da época, enquanto súditos leais e socialmente responsáveis pelo progresso de seus países, executavam missões políticas, comerciais e científicas "sob o estandarte de uma nacionalidade e de um Estado, que

transação.2 ed. São Paulo: Ed. Senac São Paulo, 2000. p. 268. É oportuno verificar algumas interpretações do sistema mundial, já que o Império português estava inserido numa rede de organização maior do que apenas sua relação com potências como Inglaterra e França no contexto do século XIX. Ver: Giovanni Arrighi. O longo século XX. Rio de Janeiro/São Paulo, Contraponto/EDUNESP, 1996.; Fernand Braudel. Civilização material, economia e capitalismo, séculos XV-XVIII. Trad. de Telma Costa. São Paulo: Martins Fontes 2009. 3 v.; Immanuel Wallerstein. O sistema mundial moderno. Porto: Afrontamento 1974. 3v.

${ }^{78}$ M. L. Pratt., Os olhos do império..., cit. p. 252-253. 
lhes conferia um sentimento de identidade e superioridade"79 Tais considerações nos permitem uma visualização mais cadenciada dos relatos escritos a partir do início dos oitocentos com os textos produzidos anteriormente: aqueles estavam a serviço da monarquia havendo, assim como no XVIII, objetivos imediatos de produtos e lucro, sempre ressaltado o caráter atual dos escritos, bem como sua importância para o avanço econômico latente das regiões visitadas. A literatura dos oitocentos se ancorava, portanto, na produção dos setecentos, mantendo-se a chave epistemológica dos relatos.

O que houve de um século para o outro foi a articulação com o industrialismo britânico e um dinamismo no comércio, além das relações políticas, permitindo a diversificação no universo retórico dos viajantes: os naturalistas podiam observar a natureza não só para fins científicos, mas também como potencial econômico, assim como os viajantes capitalistas em alguns casos mostravam-se naturalistas amadores, combinando conhecimento com métodos científicos.

Assim é que o naturalista francês Saint-Hilaire, que chegou ao Brasil em 1816, consagrou seis anos de sua vida percorrendo os territórios luso americanos "favorecido pelas autoridades locais", podendo, em suas próprias palavras, "ver tudo o que há de mais notável e reunir preciosas informações", não negligenciando, no entanto, a observação de outros aspectos que pudessem dar "uma ideia perfeita de região tão interessante". ${ }^{80}$ É evidente que os naturalistas tivessem a princípio os olhos voltados aos temas naturais. Porém, a notoriedade dada à sociedade, religião e costumes dos locais visitados constituíam também interesses de estrangeiros como ele, instigados a traçar análises e diagnósticos sobre os habitantes, mostrando-se tais aspectos como importantes no diagnostico das potencialidades que o Brasil apresentaria a seus Estados de origem, além de pretextos para a expressão de vocábulos identitários totalizadores como "brasileiro", "nação", "pátria”. A presença de europeus, segundo o viajante, daria o impulso necessário para que o Brasil estabelecesse as bases para a formação de uma sociedade civilizada, pautada no conhecimento. Para Saint-Hilaire, o caráter dos habitantes por ora não permitia o estabelecimento de relação equiparada a qualquer nível deste conhecimento, porém, enquanto indivíduo esclarecido e lúcido com relação aos caminhos a serem percorridos pelo Brasil rumo à civilização, sua obra teria o poder de trazer luzes ao futuro do país.

\footnotetext{
${ }^{79}$ A. Domingues. O Brasil nos relatos de viagem..., cit. p. 137.

${ }^{80}$ Auguste de Saint-Hillare. Viagem pelas províncias do Rio de Janeiro e Minas Gerais. Trad. de Vivaldi Moreira. Belo Horizonte/São Paulo: Itatiaia/Edusp, 1975 .p. 13-14.
} 
O comerciante inglês John Mawe, já na introdução de Viagens pelo interior do Brasil, particularmente nos distritos de ouro e diamantes daquele país, obra publicada pela primeira vez na Inglaterra em 1812, de grande repercussão, expressa a opinião de que, "quaisquer que sejam as falhas ou méritos" apresentadas pelas observações feitas durante sua viagem, "relacionam-se com assuntos atuais, extremamente interessantes, quer sob o aspecto político, quer sob o ângulo comercial" ${ }^{\prime \prime}$, opinião que aparece, de um modo geral, com frequência em relatos da primeira metade do século XIX. No início de sua narrativa, Mawe expressava a lisonjeira posição de ter sido supostamente o primeiro viajante inglês a adentrar tão longe no país, ao mencionar a recomendação que obteve para tanto do Príncipe Regente, intermediada pelo Conde de Linhares, a quem caracterizou como "pessoa dedicada às pesquisas geológicas, e desejosa de explorar o amplo campo de investigação de seus ricos e vastos domínios", sendo grato por poder realizar tal façanha com permissão e sanção do Governo, mesmo sabendo do decreto que proibia a todos os estrangeiros percorrerem o interior do Brasil. As observações de Mawe teriam o objetivo de

[...] revelar o desenvolvimento dos recursos físicos de uma colônia que, através de recentes transformações, está prestes a constituir um império e, em parte, retratar o caráter de uma nação que é e sempre foi a aliada mais fiel da Grã-Bretanha., ${ }^{82}$

A revelação do "desenvolvimento dos recursos físicos" agrega, neste sentido, questões que vão além das transformações aparentemente políticas vivenciadas por Portugal e sua principal colônia, tendo também, assim como em Saint-Hilaire, o objetivo de projetar imagens de futuro para o “jovem império”. Percebe-se, desde logo, que a intenção de promover transformações no espaço físico por meio de explorações dos recursos naturais, constitui um aspecto importante na formação deste Império, até mesmo de "retratar o caráter de uma nação", a portuguesa. A configuração de uma nova situação política, frente aos antigos paradigmas impostos pelo Antigo Regime, exigiu do Estado importações ideológicas, mas também formulações próprias, que fez a Coroa

\footnotetext{
${ }^{81}$ John Mawe. Viagens ao interior do Brasil, principalmente aos distritos do Ouro e dos Diamantes. Trad. De Solena Benevides Vianna. Rio de Janeiro: Zélio Valverde, 1944. p. 23.

${ }^{82}$ Ibidem, p. 23.
} 
portuguesa buscar pela "modernidade", almejando e introjetando com a vinda dos estrangeiros a mudança essencial para aquilo que era concebido como progresso.

Termo bastante utilizado pelos viajantes no século XIX, progresso era também preocupação proeminente no relato do negociante inglês John Luccock. A obra Notas sobre o Rio de Janeiro e partes meridionais do Brasil "teve por fito dar uma descrição fiel do País, com suas vantagens naturais, suas instituições e costumes falhos", delineando o caráter e os costumes da população, e projetando no progresso do Brasil um benefício não só para seus habitantes, mas para toda a humanidade, especialmente para os domínios britânicos. ${ }^{83}$ Interesses comerciais, atrelados à noção de progresso, colocaram de lado preocupações estritamente científicas. No prefácio da obra, é feita uma consideração a este respeito:

"Hão-de alguns achar deficientes suas descrições sobre assuntos de História Natural; mas [o autor]não presume ter a capacidade de descrever tais assuntos cientificamente; os empreendimentos comerciais não são favoráveis à aquisição de Conhecimento Filosófico [...]"»4

Mesmo que "interesse científico" e "necessidade de dominação concreta", como coloca Jitrik, não estejam estritamente relacionados aos objetivos da publicação da obra de Lucocck, a preocupação em explicar o porquê da possível deficiência científica que o texto pudesse apresentar, pode ser identificada como, no mínimo, uma releitura dos objetivos principais de outros tipos de relatos. Segundo Torrão Filho, "o viajante 'deve' aderir a uma tradição de convenções reconhecidas da literatura de viagem", porém, esta, também considerada como "gênero sem lei”, resiste a toda classificação, justamente por ser um gênero literário compósito ${ }^{85}$, passível de modificações.

O negociante inglês Henry Koster, que se tornou senhor de engenho na região norte do Brasil, apontava em Viagens ao nordeste do Brasil que jamais teve a intenção de publicar "coisa alguma do que vira neste país", sendo depois de seu regresso encorajado a "reunir todos os detalhes que pudesse comunicar" ${ }^{\text {" }}$. Koster, assim como

\footnotetext{
${ }^{83}$ John Luccock. Notas sobre o Rio de Janeiro e partes meridionais do Brasil. Tomadas durante uma estada de dez anos desse país, de 1808 a 1818. Trad. de Milton da Souza Rodrigues. São Paulo: Livraria Martins, 1942. p. XVI.

${ }^{84}$ Ibidem, p. XVI.

${ }^{85}$ A. T. Filho. A arquitetura da alteridade..., cit. p.25-26.

${ }^{86}$ Henry Koster. Viagens ao nordeste do Brasil. "Travels in Brazil". Trad. de Luiz da Câmara Cascudo. São Paulo: Companhia Editora Nacional, 1942. p. 7.
} 
outros viajantes de seu tempo, não estimava a escrita da mesma forma que um Humboldt, naturalista e explorador alemão que fez viagem exploratória pela América no final do século XVIII, para o qual a natureza primal representava interesse de primeira grandeza ${ }^{87}$. Ao contrário, foi colocado como justificativa à sua forma de escrita ao leitor sua despreocupação em registrar o que viu com detalhes ricamente científicos, ao ponto de mencionar a sensatez do público em não considerar este detalhe como aspecto importante:

Espero que o leitor queira por bem escusar os defeitos que possa descobrir neste livro quando saiba que não fiz observações seguidas no Brasil com pensamento de publicar os resultados [...] O leitor sensato dará pouca importância ao estilo de um livro da natureza deste." $" 88$

Percebemos aqui também uma releitura na forma de escrita do viajante com em comparação com os relatos produzidos anteriormente. $\mathrm{O}$ interesse do público leitor pelas novidades de um mundo para eles desconhecido, neste momento, provinha, na maior parte das vezes, de livros sem aspirações literárias, que muitas vezes traziam imagens repetitivas sobre o local visitado, característica observada nas narrativas de viagem analisadas. Guardadas as semelhanças dos relatos de viagem dos oitocentos com relatos de outros séculos, "esta onda de viajantes-escritores frequentemente assumia uma postura conscientemente antiestética em seus escritos, introduzindo retóricas pragmáticas e econômicas", que se apartavam de esteticismos e formas mais elegantes de escrita. ${ }^{89}$

A fidelidade com a verdade, ou seja, a forma como "escreviam sobre aquilo que viram pessoalmente ou sobre o que ouviram de fonte confiável", mostrava-se para autores como Maria Graham, escritora inglesa que se tornou em 1823 preceptora da princesa D. Maria da Glória e que publicou em 1820 na Inglaterra Diário de uma viagem ao Brasil e de uma estada nesse país durante parte dos anos 1821, 1822 e 1823, como aspectos poucos importantes para a qualidade da obra:

\footnotetext{
${ }^{87}$ M. L. Pratt, Os olhos do império..., cit., p.

${ }^{88}$ H. Koster. Viagens ao nordeste do Brasil..., cit. p. 7.

${ }^{89}$ M. L.Pratt, Os olhos do império..., cit. p. 257- 258.
} 
“A autora não tem pretensões à perfeita imparcialidade, pois nem sempre esta significa virtude. Mas, sabendo que nenhum bem humano pode ser alcançado sem certa dose de mal, espera ter sempre encarado as questões pelos dois lados, ainda que isto lhe tenha custado bastante esforço na composição." 90

Imparcialidade e verdade seriam características dependentes de outros aspectos, segundo ela, como fatos relatados por terceiros "deformados pelas fontes interessadas através das quais chegaram ao público", ou mesmo informações alteradas "pela ignorância dos informantes; e a maior parte pelo espírito partidário [...]" ${ }^{, 91} \mathrm{~A}$ obra de Graham, segundo análise de Moreira Leite, "não se destaca apenas entre os diários de viagem escritos por mulheres", mas é significativa dentro do gênero de literatura de viagem, principalmente, pela preocupação com o público e "por seu nível de percepção e informação" ${ }^{92}$, valorizando a imparcialidade e veracidade, que nas narrativas de viagem do século XVIII constituíam aspectos de cientificidade e importância.

Também foram essas algumas das apreensões de Saint-Hilaire, que se preocupou, ao menos em seus objetivos iniciais, em não estender-se em reflexões, "procurando apresentar os fatos sob o seu aspecto real, deixando, na maioria das vezes, ao leitor, tirar por si as consequências" ${ }^{, 93}$. Nestes termos, o autor ressalta:

"Levei o escrúpulo da exatidão ao máximo; e, devo confessa-lo, preocupei mais em pintar com fidelidade o que observei do que em limar o estilo. É preciso convir, porém, que o viajante não pode ver tudo com seus próprios olhos [...] obrigado a basear-se nas informações de outrem, e, consequentemente, está sujeito a enganar-se. É possível que mais de uma vez, me tenha isso sucedido; mas será somente nesses casos que terei induzido em erro aos que me lerem.",94

\footnotetext{
${ }^{90}$ Maria Graham. Diário de uma viagem ao Brasil e de uma estada nesse país durante parte dos anos 1821, 1822 e 1823. Trad. de Américo Jacobina Lacombe. São Paulo: Cia. Editora Nacional, 1956. p. XV. ${ }^{91}$ Ibidem, p. XV.

${ }^{92}$ Miriam L. Moreira Leite. Livros de Viagem (1803-1900). Rio de Janeiro: UFRJ, 1997. p. 34.; ver também, da mesma autora, A mulher no Rio de janeiro no século XIX: um índice de referências em livros de viajantes estrangeiros. São Paulo: Fundação Carlos Chagas, 1982.

${ }^{93}$ A. Saint-Hilaire, Viagem pelas províncias do Rio de Janeiro..., cit. p. 14.

${ }^{94}$ Ibidem, p. 14-15.
} 
Mesmo que fatores como a imparcialidade sejam interpretados pelos viajantes escritores do século XIX de formas diferentes, o fato é que esta é uma preocupação entre os que viajavam e disponibilizavam ao público os seus registros. Mais para uns e menos para outros, a fidelidade com que as informações seriam transmitidas aos leitores constituía aspecto que daria à escrita ares de importância, mesmo que muitos desses viajantes tenham expressado a não intencionalidade em publicar suas obras. Objetividade, imparcialidade e veracidade, enquanto objetivos, constituem, portanto, traços característicos dos relatos de viagem dos oitocentos, ainda que com intenções diversas dos viajantes do século XVIII, dos quais são herdeiros.

Entre as diversas motivações em viajar para o Brasil, podemos destacar a presença de Debret, um artista que mostrou preocupação em elaborar um discurso histórico sobre o Brasil, fazendo das "imagens e dos temas tratados uma contribuição que objetivava [...] contribuir para elevar o Brasil à categoria de nação civilizada." ${ }^{95}$ Antes de mais nada, Debret apontava para a importância de poder admirar a beleza do Brasil e, principalmente, a glória de "propagar os conhecimentos das belas artes entre um povo ainda na infância", imprimindo nesse mundo as marcas "profundas e úteis" da presença francesa ${ }^{96}$. Segundo ele,

“Graças ao hábito da observação, natural em um pintor de história, fui levado a empreender espontaneamente traços característicos dos objetos que me envolviam; por isso, meus esboços feitos no Brasil, reproduzem, especialmente, as cenas nacionais ou familiares do povo entre o qual passei dezesseis anos." 97

Apesar da importância de ressaltar seu olhar de pintor, historiador, filósofo, a fim de se ter uma visão adequada de suas contribuições na construção de uma imagem sobre o Brasil e de suas características frente à literatura de viagem produzida no século XIX, a percepção da condição de viajante foi o elemento com o qual o artista caracterizou sua

\footnotetext{
${ }^{95}$ Valeria Lima, Valéria Lima. J.-B. Debret, historiador e pintor: a viagem pitoresca e histórica ao Brasil (1816-1819). Campinas-SP: Editora da Unicamp, 2007. p. 129.

${ }^{96}$ Jean Baptiste Debret. Viagem pitoresca e histórica ao Brasil.2. v. Trad de Sergio Milliet. São Paulo: Itatiaia. 1978. p.23.

${ }^{97}$ Ibidem, p. 24.
} 
obra, assim como outros viajantes escritores do período: "uma descrição fiel do caráter e dos hábitos dos brasileiros em geral" ${ }^{\prime 98}$.

Descrições sobre os hábitos, os recursos naturais, fauna, flora, situação política do Brasil e Portugal, prognósticos de futuro, entre tantos outros aspectos, direta ou indiretamente, podem ser analisados dentro do escopo maior da estrutura mundial, pautada pela expansão capitalista e neocolonialista do século XIX. Mudanças na forma estética da escrita, a aparição da natureza enquanto potencialidade a ser explorada, com vistas ao progresso, seja pelo comércio, ou mesmo por meio da arte como meio de se obter instrução, como observamos em Debret, a combinação de conhecimento e empreendimento, ao contrário de se manifestarem enquanto inauguradores de um "redescobrimento" do Brasil, tem seu passado. As disputas de poder entre as potências europeias tiveram como uma de suas ferramentas a observação direta, que se apresentou aos viajantes oitocentistas como forma de enriquecimento e conquista.

A viagem é mais do que fonte de conhecimento e informação, ela é um método de investigação do mundo ${ }^{99}$, utilizada pelos viajantes que visitaram o Brasil no século XIX, mas que não foi ignorada até que as conjunturas políticas permitissem a plena exploração das terras luso americana. Pelo contrário, foi método também de muitos homens do século anterior, instigados pela ciência e novas descobertas. Em termos de cultura - crenças, festejos, dias santos, formas de vestimenta, de comportamento, de relacionamento, entre outros elementos-, as discrepâncias da sociedade, em grande medida, também eram oriundas do tipo societário do Brasil, disparidades que contavam ainda com imagem invertida de si mesmos que os estrangeiros imprimiam em suas descrições. O próximo item irá tratar desta visão de mundo dentro da qual os habitantes do Brasil são analisados pelos viajante, por meio de referenciais de cultura pautado pela ideia eurocêntrica de superioridade.

\subsection{Visões de mundo, espaços e experiências vividas}

Os viajantes, enquanto sujeitos socioculturais permeados por referenciais de cultura, costumes e tradições específicas de seu tempo e espaço, sobretudo os de origem e formação, buscavam na diversidade do que encontraram nas viagens a identificação de si mesmos. A concepção de alteridade é fator importante nesta análise na medida em

\footnotetext{
${ }^{98}$ Ibidem, p. 26. O termo "brasileiro" será melhor analisado no capítulo 2.

${ }^{99}$ A. T. Filho. A arquitetura da alteridade..., cit. p. 7.
} 
que podemos identificá-la como pressuposto básico de todo indivíduo que vive em sociedade. ${ }^{100}$ Assim é que os viajantes estrangeiros reforçavam, enquanto elementos integrantes de uma sociedade em expansão, seus referenciais de cultura da qual faziam parte, interagindo com o outro. Podemos identificar, então, que a diferença entre o eu e o outro é elemento indispensável para a afirmação da alteridade, que nada mais é do que a interação do indivíduo com o que lhe é diferente, e que se defini, portanto, a partir da inter-relação entre as partes. A construção textual dos viajantes aborda, neste sentido, uma representação da diferença e nestes termos é que, segundo Hartog, "classificando o outro, classifico-me a mim mesmo e tudo se passa como se a tradução se fizesse sempre na esfera da versão"

A presunção de superioridade dos viajantes europeus, por sua vez, frente aos habitantes dos locais visitados é resultado da autodeterminação que consequentemente inferioriza uma das partes no olhar da outra. ${ }^{102}$ No entanto, a própria relação alteridade/identidade, que cria juízos e conceitos dentro do processo de formação identitária no Brasil, abarcados nesta pesquisa, estabelece imagens pensadas pelos estrangeiros a respeito do habitante do local visitado que podem ter tido a capacidade de ressignificação e reforço de uma imagem por oposição.

A partir desta postura de superioridade do europeu, imposta por uma suposta hierarquia, que muitas vezes imputou imagens negativas aos luso americanos, projeções de futuro e descrições sobre o Brasil e seus habitantes foram lançados pelos viajantes. Entendê-los a partir da conjuntura em que produziram seus relatos torna mais pertinente perceber a forma como encararam a sociedade que encontraram na América. Segundo Torrão Filho, "um viajante quase sempre tem projetos políticos, sociais ou filantrópicos, e os espaços exóticos, são um campo fértil no qual eles podem teorizar a aplicação de suas ideias", entendendo-se, neste sentido, que o que determina a descrição nos relatos não é apenas o contato com o mundo não europeu, mas é resultado também de reflexões

\footnotetext{
${ }^{100}$ Todorov, por exemplo, discute a alteridade no contexto de descobrimento da América. Nesta análise está proposto que o encontro do europeu com o indígena não contou com o elemento da surpresa absoluta por parte dos espanhóis. Uma das interpretações anunciadas pelo autor está no que ele chamou de causalidade direta, ao admitir que a identidade ocidental como a conhecemos teria sido anunciada com a conquista da América, proclamando serem todos "descendentes diretos de Colombo" Tzvetan Todorov. A Conquista da América. A questão do outro. São Paulo: Martins Fontes, 1983, p. 6.

${ }^{101}$ François Hartog. O espelho de Heródoto. Ensaio sobre a representação do outro. Trad. Jacynto Lins Brandão. Belo Horizonte: UFMG, 1999.p. 259.

${ }^{102}$ Eva Maria Afonso Moreira da Cruz Dinis. Dois olhares sobre a alteridade: o Outro em A correspondência de Fradique Mendes, de Eça de Queirós, e Nação Crioula, de José Eduardo Agualusa. Dissertação de mestrado. Faculdade de Letras/Universidade de Lisboa, Lisboa, 2009. p. 17.
} 
que são anteriores à viagem ${ }^{103}$; nesse ponto, a ideia de superioridade europeia com relação ao Brasil era um dado a ser considerado. As preocupações dos viajantes britânicos e franceses e de outras nacionalidades que visitaram o Brasil no começo do século XIX estavam inscritas em questões de cunho liberal/civilizador. Tais demandas resultavam em opiniões a respeito do que viram durante a viagem, expostas sob o viés da representação cultural europeia, a fim de se estabelecerem aqui as bases ideológicas de concepções eurocêntricas, que introduziam num ambiente propício a tais mudanças concepções de trabalho, propriedade, transformação do espaço e da moral dos habitantes. ${ }^{104}$ Estas sempre estiveram patentes na visão de alteridade que o viajante estrangeiro imputou às observações feitas sobre o Novo Mundo, consequentemente na de superioridade/inferioridade também.

Juntamente com a perspectiva de superioridade do europeu e, por isso, a acreditada responsabilidade de direcionar um mundo inóspito aos caminhos da civilização por meio de práticas e valores do mundo de origem, deve-se considerar que a crítica destes "arautos" da sabedoria e da boa moral esteve influenciada por referenciais de cultura muitas vezes incompatíveis com os sincretismos da sociedade escravista presente na América portuguesa. ${ }^{105}$ Tal contraste foi fundamental para os viajantes pensarem o que pensaram acerca dos habitantes da terra. Tanto as práticas produtivas, de relacionamento, ou mesmo as de religiosidade, base da conquista e colonização do Brasil, subsidiaram visões dos viajantes que construíram, a partir delas, formas de discurso sobre seus habitantes. Isto levou a diagnósticos e à concretização de uma imagem sobre o Brasil e os "brasileiros", tema tratado de forma mais minuciosa no próximo capítulo.

A construção vocabular de expressões identitárias em referência aos habitantes do Brasil nas narrativas de viajantes estrangeiros que o visitaram e sobre ele escreveram está inserida, neste sentido, em discursos edificados em critérios e julgamentos que tomavam por parâmetro a diferença, na qual num dos extremos supostamente se configuraria a vida civilizada e no outro a sociedade que se encontrava em estado de inferioridade. Assim, no campo da versão, o contato com o outro permitia a existência

\footnotetext{
${ }^{103}$ A. T. Filho. A arquitetura da alteridade..., cit., p. 4-5.

${ }^{104}$ José Carlos Barreiro. Imaginários e viajantes no Brasil do século XIX: cultura e cotidiano, tradição e resistência. São Paulo: Unesp, 2002; M. L. Pratt. Os olhos do império..., cit.

${ }^{105}$ Ilka Boaventura Leite. Antropologia da viagem : escravos e libertos em Minas Gerais no século XIX. Belo Horizonte: Editora UFMG, 1996. Este trabalho oferece uma análise sobre os relatos de viagem do século XIX como textos pré-etnográficos, abordando o estranhamento e a reflexão do estrangeiro com o "outro" como fruto das observações das diferenças, forjando-se uma imagem do negro na América, em oposição à imagem do europeu.
} 
de um "eu", reforçando os referenciais culturais dos viajantes, como também estabeleceu a construção de uma imagem dos habitantes observados e descritos, a partir da relação com este outro.

Neste processo, a viagem a países católicos, no caso de britânicos, ou para nações “atrasadas", no caso de católicos franceses, obrigava atenção à alteridade pelo viajante: as representações dentro do mesmo esquema conceitual ao qual britânicos, franceses e luso americanos estavam inseridos, em comparação a viagens a países islâmicos, por exemplo, o estranhamento causado devia-se em grande parte pelo fato de viajantes e residentes do país visitado não se reconhecerem como integrantes do mesmo mundo, apesar da proximidade desses universos simbólicos. ${ }^{106}$

Do mesmo modo, o distanciamento pode ser observado com relação às noções de trabalho e propriedade, que abarcavam outras tantas categorias, tais como o nível de instrução dos habitantes do Brasil, as transformações do espaço físico em favor do lucro, etc., na medida em que o imaginário das classes sociais estava associado à tradições específicas de uma sociedade colonial que tinha com a natureza uma relação diferente da estabelecida pelos viajantes europeus. ${ }^{107}$

Assim é que descrições das festas, cerimônias, hábitos alimentares, sociabilidade, vestimenta, formas de produção, prática dos ofícios, dentre muitos outros aspectos anotados pelos estrangeiros, não estranhamente estão quase sempre ligadas a questões de moral e de "atraso" dos luso americanos, em relação ao que supostamente se observava na Europa. E para compreender a interpretação dos viajantes sobre o que viram é pertinente entender o discurso como prática da linguagem, "uma narrativa construída a partir de condições históricas e sociais específicas”, que materializa uma determinada ideologia nos atos de fala e configura "uma representação do imaginário no qual o autor está inserido", ou seja, trata-se de analisar, indo além de seu conteúdo, os elementos linguísticos, históricos e sociais do texto que ganham sentido em conjunto e reformulam relações sociais. ${ }^{108}$

Tal abordagem, no que diz respeito às identidades coletivas relativas ao Brasil, assume importância na medida em que as descrições dos habitantes da América

\footnotetext{
${ }^{106}$ A. T. Filho. A arquitetura da alteridade..., cit ., p. 222.

107 J. C. Barreiro faz a análise deste imaginário nas "classes subalternas", empregando conceitos de propriedade e trabalho que na sua acepção moderna efetivaram-se progressivamente na Europa entre os séculos XVI e XVIII, por meio da investigação dos viajantes e a partir destes a reconstituição do cotidiano e das lutas das classes sociais da sociedade luso americana do século XIX. Imaginários $e$ viajantes no Brasil..., cit., p.9-10.

${ }^{108}$ Kalina Vanderlei Silva \&Maciel Henrique Silva. Discurso. Dicionário de Conceitos Históricos. São Paulo: Contexto, 2005, p. 101.
} 
portuguesa, sintetizados muitas vezes no termo "brasileiro", estão inseridas no universo ideológico dos viajantes e de modo geral apartados dos referenciais de cultura e sociabilidade dos habitantes, no caso de "brasileiros", mas também das próprias linguagens políticas do império português. Há uma dificuldade em decifrar as práticas híbridas da América portuguesa com o universo simbólico do estrangeiro ${ }^{109}$, no qual a visão desencontrada com o aparato cultural dos viajantes, muito além da simples constatação da adversidade encontrada nos trópicos, emoldura, na visão estrangeira, caracteres de um grupo humano pautado quase sempre pela promiscuidade e atraso. Ainda que depreciando os modos de vida, conduta e moral dos habitantes, não obstante, alguns viajantes vão se identificar positivamente com os "brasileiros", como veremos adiante. O fascínio que a gente do Brasil exerceu sobre os viajantes estrangeiros resultou não raro em contradições, que surgem como dado construtivo na formação de uma imagem sobre o Brasil e os seus habitantes.

As mudanças da vida social, entre festejos, alteração no ritmo de vida, hábitos transformados, em conjunto com tantos outros elementos sensíveis à vinda da Corte, apontam o pano de fundo na concretização de uma imagem criada pelos estrangeiros que viria a ter espaço entre os próprios habitantes do Brasil, transformando-se em pontos de referência para a uma futura "identidade brasileira", marcada por características que os diferenciavam de outros grupos humanos, supostamente com traços, hábitos e costumes diferentes.

Alguns dos costumes mais arraigados das populações do Brasil tiveram nas festas - que se confundiam com ocasiões religiosas - momentos propícios a intensas observações a respeito dos que residiam no país, trazendo a tona seus hábitos e modos, muitas vezes julgados como impróprios, ou ao menos, num estágio de desenvolvimento incompatível com o que se esperava de uma sociedade que almejava o "progresso" e a "civilidade".

De maneira quase sempre aberta às experiências que a vida no Brasil lhe proporcionaria, Koster descrevia as festas religiosas como "tempos de agitação e alegria", época em que se apresentavam momentos de "alvoroço e distração". Sua residência no Brasil e a consequente "mudança de hábitos que esse gênero de vida exigia”, tão diversos dos vividos na Inglaterra, eram reanimadas, segundo ele, por conhecer o idioma do país e pela resolução de que se submeteria aos "costumes do

\footnotetext{
${ }^{109}$ A. T. Filho. A arquitetura da alteridade..., citp. 232.
} 
povo", chegando à conclusão de que "não era demasiado idoso para ter hábitos tão arraigados que não pudesse ceder quando necessário." ${ }^{110}$ Porém, apesar de sua postura quanto à adaptação aos costumes dos habitantes, Koster não deixou de mencionar características estranhas aos estrangeiros, de modo geral, sempre aventadas pelos viajantes britânicos analisados. Um destes aspectos observados por ele foi as maneiras católicas adotadas pelos luso americanos.

Em viagem de Natal ao Assú, durante a primeira temporada em que esteve no Brasil, de 1809 a 1815, Koster descreve um "hábito curioso" em regiões muito afastadas umas das outras:

“Certos padres obtém licença do Bispo de Pernambuco e viajam nesses lugares com um altar portátil, construídos para esse fim, conduzido por um cavalo, assim como todos os objetos para as missas [...] Esses padres, no curso de um ano, ganham de 150 a 200 £, renda considerável para o Brasil, mas dificilmente conseguida se pensarmos nos sofrimentos e privações que foram obrigados a suportar. Eles param, erguem o altar onde existe um certo número de pessoas que podem pagar para ouvir a missa [...] Esses padres tem sua missão no mundo. Se essa tradição não existisse todo culto era impossível para os habitantes de muitos distritos, ou bem, eles não podia assistir um serviço religioso senão uma ou duas vezes por ano [...] e nessas paragens em que não há lei nem religião real e racional, alguma coisa é melhor que coisa alguma [...] É o liame que prende todo esse povo e o sustenta, no fio das ideias recebidas, junto às populações maiores de outros distritos."

Apesar de considerações que afirmassem as benesses de alguma religiosidade no lugar de nenhuma, num país com suas próprias regras de sociabilidade, apartadas da matriz europeia da qual eram os viajantes portadores, Koster não se absteve da opinião de que a religião estaria limitada a certas fórmulas e frequente repetição de cerimônias e orações, "crenças nas encantações, relíquias e outras coisas da mesma ordem.".112 Tamanha era a crença que os habitantes do Brasil teriam em aspectos para ele

\footnotetext{
${ }^{110}$ H. Koster. Viagens ao nordeste do Brasil..., cit p.99.

${ }^{111}$ Ibidem, p. 131-132.

${ }^{112}$ Ibidem, p. 206.
} 
superficiais e um tanto ingênuos com relação à religião, que o viajante afirmava ser a fé nestas paragens capaz de realizar o que não era possível à medicina, tal era a confiança na eficácia das orações e nos santos devotos. ${ }^{113}$ Não havia, segundo Koster, "nenhuma persuasão, nenhum raciocínio sobre esse assunto", nem mesmo das classe altas, as quais supunha-se discernimento maior que nas classes populares, mas que no Brasil, segundo ele, não distinguiam-se em se tratando de crenças. ${ }^{114}$

A suposta falta de compostura dos habitantes em cerimônias religiosas, ou mesmo em demonstrações costumeiras de fé no catolicismo, foi crítica constante dos viajantes, não escapando da pena destes ávidos observadores nem mesmo o clero. No diário da viagem de Maria Graham ao Brasil, publicado em 1824 na Inglaterra, a viajante, em observações feitas sobre os clérigos do Brasil, afirmava que seus costumes eram aqui os mais depravados. ${ }^{115}$ Um pouco mais condescendente, Saint-Hilaire observou que se os sacerdotes aqui não eram isentos de defeitos, reconhecia com prazer que não eram hipócritas: mostravam-se tais quais eram e não usavam de discursos solenes e atitudes austeras, podendo ser confundidos, pelas maneiras no vestir, com os leigos. ${ }^{116}$

Em excursão pelo entorno do Rio de Janeiro em 1816, Luccock também notou as manifestações religiosas dos habitantes, durante a Páscoa, ao "ouvir reza" numa capela pertencente a uma residência particular:

"Embora [alguns ingleses] estivessem a conversar alegremente com a família e outras visitas, faziam-no em tom baixo, em consideração à cerimonia religiosa que se estava desenvolvendo; todavia, a pilherias, sorrisos e risadas desabridas, que se viam e ouviam por ali tudo, bem demonstrava quão longe se achavam os ânimos todos de qualquer pensamento grave ou devota reverência. $\mathrm{Na}$ realidade, os próprios clérigos são em geral tão culpados de semelhante ausência de decoro, em suas sedes sagradas como nas suas diligencias, que bem mostram que não se consideram senão como atores, a cada um dos quais cabe representar determinado papel no drama do dia. Pareceu que somente exigem que, por ocasiões tais, o povo apenas dobre os joelhos, baixe a cabeça, persigne-se e

\footnotetext{
${ }^{113}$ Ver Laura de Melo e Souza. Diabo e terra de Santa Cruz. Feitiçaria e religiosidade popular no Brasil colonial. São Paulo: Cia das letras, 2009.

${ }^{114}$ H. Koster. Viagens ao nordeste do Brasil..., cit. p. 302-303.

${ }^{115}$ M. Graham. Diário de uma viagem ao Brasil..., cit., p. 121.

${ }^{116}$ A. Saint-Hilaire. Viagem pelas províncias do Rio..., cit., .p. 164.
} 
bata no peito, nos devidos momentos da missa, pronunciando seus responsos em uníssono." $" 117$

Parte integrante da cultura religiosa em Portugal desde a época dos descobrimentos, as celebrações religiosas tinham, a rigor, espaço consagrado e obrigatório na vida dos cristãos. No Brasil, a despeito de um estudioso contemporâneo da matéria, a "débil tradição associativa", entre outros elementos de ordem física, como a inospitalidade de território, levou a uma adaptação das celebrações religiosas, ou mesmo o abandono de algumas, além de segregações sociais, protegendo a elite branca, "acastelada e minoritária demograficamente [...] da arraia-miúda e da gentalha de cor", exaltada principalmente devido à construção de seus próprios locais de culto, como as capelas, anexas ao local de moradia. ${ }^{118}$ Seja como for, a religiosidade entendida pelos estrangeiros como algo "fora de lugar" era alvo de críticas e incompreensões da parte dos viajantes do começo do século XIX, que viam nas práticas de fé apenas atos levianos, de pouca ou nenhuma demonstração de devoção.

Estas impressões estão geralmente relacionadas, na maioria das descrições dos viajantes analisados, ao entrelaçamento das cerimônias religiosas com os divertimentos. Tanto no Rio de Janeiro quanto em outros lugares da colônia, Mawe observou que realizavam-se procissões religiosas "nos grandes dias de festa e nos dias de graça, comemorando-se estas ocasiões com vários divertimentos" que duravam de manhã até a noite. ${ }^{119}$. Consistiam em oportunidades para os habitantes aproveitarem momentos de convívio intersexual, de trocarem bilhetes furtivos e "tocarem maliciosamente o corpo das nem sempre circunspectas donzelas ou matronas." ${ }^{120} \mathrm{O}$ entrelaçamento de motivos divinos com os profanos configurava, neste sentido, a multifacetada sociedade colonial que conformou sua própria forma de sociabilidade dentro dos parâmetros disponíveis. E a religiosidade estava no centro dos relacionamentos estabelecidos em torno de todos os grupos sociais, aproximando-os em determinadas ocasiões, ao passo que distanciava em outras.

\footnotetext{
${ }^{117}$ J. Luccock. Notas sobre o Rio de Janeiro..., cit., p. 233.

${ }^{118}$ Luiz Mott. Cotidiano e vivência religiosa: entre a capela e calundu. In: Laura de Melo e Souza (org.) História da vida privada no Brasil: cotidiano e vida privada na América portuguesa. São Paulo: Cia. das Letras, 1997.p. 160-161. Algumas contribuições em Riolando Azzi. (org.) A vida religiosa no Brasil. Enfoques históricos. São Paulo: Paulinas, 1983.

${ }_{119}$ J. Mawe. Viagem ao interior do Brasil.., cit., p. 190.

${ }^{120}$ L. Mott. Cotidiano e vivência religiosa..., cit., p.161-162.
} 
Imputando às observações feitas destes momentos de "distração" um ar de "brejeirice", Luccock afirmava que dificilmente os festejos católicos observados por ele poderiam ser atribuídos a raízes religiosas. Ele descreveu uma destas ocasiões em 1809, na época de Cinzas, anunciando o início da quaresma, tempo consagrado à folia que era chamado entre os habitantes de "intrudo":

"Por ocasião do intrudo [...] fazem bolas ocas de cera, de cores variegadas, mais ou menos do tamanho de um laranja, encham-nas d'água e bombardeiam-se mutuamente, até que os combatentes fiquem completamente molhados,. Conjecturou-se que esse foi um dos primitivos modos singulares pelo qual os padres impunham a água batismal às pessoas pouco dispostas a recebe-la, assim forçando-os para dentro dos Reinos dos Céus [...] [Também] embrulha-se farinha de trigo em cartuchos de papel e, de surpresa, quando um pobre negro se encontra distraído, fazem-no todo branco. De tal maneira gosta o povo desses e de outros divertimentos, que dizem todos abertamente: no entrudo ficamos todos bobos."121

Koster teve também teve a oportunidade de observar o intrudo, em 1812, diferentemente de Lucocck, mais aberto às novidades que a residência no Brasil lhe proporcionava:

"Nosso grupo não podia deixar passar a oportunidade sem praticar o divertimento do intrudo mesmo que a época de sua celebração ainda estivesse longe uma semana. No dia seguinte a nossa vinda, mal findo o jantar, a farinha, as bananas, o arroz e outras guloseimas da mesa, eram atiradas à cabeça uns dos outros. Depressa os uniformes elegantes foram desaparecendo e foi em mangas de camisa que começou a guerra civil com alma e coração. Tudo se passava na mais perfeita alegria e, por fim, fatigados e sujos, todos nós procuramos as redes, abundantemente espalhadas para os hospedes [...] Chegamos à casa do capitão Paulo Travasso, distante uma légua [...] o intrudo continuou com mais violência

${ }^{121}$ J. Luccock. Notas sobre o Rio de Janeiro... cit., p. 129. 
que anteriormente. Potes e panelas saíram da cozinha e foram introduzidos para enegrecer e besuntar-nos os rostos a todos." 122

Participantes ou não dos divertimentos que as festa religiosas proporcionavam aos habitantes, o fato é que para alguns britânicos, protestantes cabe lembrar, ocasiões como estas levaram a cristalização de uma imagem pouco lisonjeira dos luso americanos, já que por meio dos seus entretenimentos é que, segundo Luccock, uma comunidade era bem retratada, expondo suas maneiras de agir e pensar. ${ }^{123}$ No entanto, a diferença de religião entre franceses e britânicos não implicou em imagens muito distintas da religiosidade no Brasil, como bem lembrou Torrão Filho. Segundo o autor, os franceses católicos retrataram as cerimônias religiosas "praticamente com as mesmas cores que seus contemporâneos protestantes, talvez com uma pequena diferença, ao insistirem menos na 'idolatria' e no culto às imagens, pecado do qual, afinal, também poderiam ser acusados." 124 Saint-Hilaire, observando os modos alimentares em datas específicas do calendário católico, relatou que um inglês teria visto muitos viajantes indo ao Rio de Janeiro em dia santo, e que com muita dificuldade conseguiu que lhe vendesse uma galinha, só conseguida pelo dobro de seu valor real e sob muita censura, admitindo que não se recordava de ter visto nada parecido que "indicasse serem os Brasileiros observantes tão judaicos" em dias santos como pretendiam ser e nem que alimentar-se de galinhas nesses dias fosse prática proibida em nenhum outro país católico. ${ }^{125}$ As discrepâncias continuavam com relação à ornamentação dos edifícios religiosos, concluindo que estes ganhavam em importância e eram melhor iluminados se comparadas aos da França. ${ }^{126}$ Notou que a mais ínfima povoação possuía de cinco a seis templos, que mal uma confraria dispunha de recursos se iniciava a construção de mais uma igreja:

\footnotetext{
${ }^{122}$ H. Koster. Viagens ao nordeste do Brasil..., cit., p. 272-274. Em nota, Koster esclarece que "segundas e terças-feiras antes de Cinzas são os dias próprios para o intrudo mas o divertimento, como no caso vigente, pode começar uma semana antes do prazo. Água e pós para cabelo são os ingredientes indicados para lançarem uns aos outros, mas, frequentemente não guardam equilíbrio e tudo quanto se pode agarrar, esteja limpo ou sujo, é atirado, de todas as partes, para inocentes ou culpados."

${ }^{123}$ J. Luccock. Notas sobre o Rio de Janeiro... cit., p. 129.

${ }^{124}$ A. T. Filho. A arquitetura da alteridade..., cit., p. 228.

${ }^{125}$ A. Saint-Hilaire. Viagem pelas províncias do Rio..., cit., .p. 102. A forma como o viajante emprega o termo "brasileiro" será analisada no próximo capítulo.

${ }^{126}$ Ibidem, p. 117-118.
} 
Constroem-se templos sem necessidade, fazem-se despesas loucas para celebrar os padroeiros com festividades quase pagãs, e, como já o fiz notar alhures, não se pensa em fundar estabelecimentos de caridade, hospitais, escolhas gratuitas, etc., etc. Nem mesmo se pode dizer que para isso concorra uma piedade mal entendida; na maioria das vezes a causa é a vaidade. As irmandades rivalizam entre si e procuram distinguir-se por esbanjamentos inúteis. ${ }^{127}$

Cabe lembrar que as cerimônias e os rituais públicos tiveram função catalisadora na sociedade, e funcionavam, como salientou Durkheim, igualmente como mecanismo de controle social e manutenção da rígida hierarquia da "igreja militante." 128 Ordenador da vida social na colônia portuguesa, o catolicismo tinha o papel de integrar o conjunto da monarquia, de modo geral, e, especificamente, as partes distintas e isoladas do território luso americano, afastados geograficamente das bases que supostamente fundamentavam a conduta portuguesa, que teve na religião católica um de seus pilares, readaptados ao ambiente colonial. ${ }^{129}$

O fato é que durante os festejos públicos o ritmo da vida habitual da colônia ganhava movimento e estampava-se a oportunidade de aparição pública, ao passo que os sentimentos religiosos ou cívicos transformavam-se em pretextos à sociabilidade, moldando ainda que sutilmente uma identidade. Os sujeitos históricos integrados nestes atos agiam e interagiam, articulando ideias, interesses pessoais e/ou grupais e manifestações coletivas que podem privilegiar o estudo das representações políticas. ${ }^{130}$ E as movimentações causadas pelos festejos, portanto, consistiam em tempos de propícias observações por parte dos viajantes que viam nestas ocasiões a chance de descrever os habitantes e seus costumes.

\footnotetext{
${ }^{127}$ Ibidem, p. 159-160.

${ }^{128}$ Citado por L. Mott. Cotidiano e vivência religiosa... , cit., ver também E. Durkheim. As formas elementares da vida religiosa. São Paulo: Martins Fontes, 1996.

${ }^{129}$ Lilia Mortiz Schwarcz observa que não só o calendário oficial espantava os viajantes europeus, mas os rituais populares, imersos no que ela chama de "catolicismo mulato", causavam estranhamento ainda maior devido ao caráter misturado dos cultos. Segundo ela, as festas, no interior de palácios e teatros para os "brancos", e nas ruas e senzalas para a gente pobre e escrava, convergiam-se nos rituais religiosos, num mesmo espaço que comungava "algo além da hóstia sagrada". Lilia Mortiz Schwarcz. Viajantes em meio ao império das festas. In: István Jancsó\& Iris Kantor (orgs.). Festa. Cultura e sociabilidade na América portuguesa. Vol.2. São Paulo: Hucitec. p. 611-612.

${ }^{130}$ Emilio Carlos Rodriguez Lopez. Festas públicas, memória e representação: um estudo sobre manifestações políticas na Corte do Rio de Janeiro, 1808-1822. São Paulo: Humanitas, 2004. p. 14.
} 
No início do século XIX, quando a religiosidade marcava o compasso da vida no Brasil, as ocasiões sociais apresentavam-se aos viajantes como oportunidades de observar uma momentânea mudança de costumes dos habitantes, como a presença das mulheres nas ruas ${ }^{131}$, da alta ou baixa sociedade, ou até mesmo um afrouxamento das hierarquias sociais estabelecidas numa sociedade colonial. Nos "divertimentos religiosos", assim podemos chamar, Koster tem uma das poucas oportunidades de interação com o sexo feminino no interior da vida doméstica da colônia em começos do século XIX. ${ }^{132}$

Numa Quinta-Feira Santa, Koster observou que "muitas estavam vestidas de sedas de várias cores e cobertas de correntes de ouro e outras bugigangas, e em geral expunham tudo que de mais fino tinham podido reunir", ressaltando também uma sutil mudança na hierarquia social, ao notar que as mulheres ao entrar na igreja, por exemplo, permaneciam juntas sentando-se no chão ou no espaço aberto para elas no centro, fosse qual fosse sua posição social ou cor. ${ }^{133}$ As clivagens sociais e raciais dissolviam-se parcialmente em ocasiões religiosas, ainda que momentaneamente, e guardavam relação com a sociabilidade, numa sociedade escravista na qual estavam postos parâmetros de cor, posição social, profissão, etc., influenciando de certo modo na configuração constante das identidades.

Sobre cerimônias e festas religiosas, Luccock também observava o efeito duradouro que estas causavam na sociabilidade das mulheres:

“[...] a igreja é aberta a todos e suas práticas interessam igualmente a ambos os sexos; por isso, pais e maridos se viram compelidos, sob a nova ordem de cousas, a afrouxar a disciplina caseira e abrir as portas de seus harens. Do momento em que se concedeu certo grau de liberdade às prisioneiras, tornou-se impossível manter-lhes a reclusão. Tinha-se que visitar umas tantas capelas, as concessões por que ansiavam as damas tinham que ser imploradas sobre os altares,, as promessas tinham que ser pagas aos santos padroeiros em dias e locais mais especialmente consagrados a semelhantes

\footnotetext{
${ }^{131} \mathrm{O}$ espaço de sociabilidade das mulheres concentrava-se nas igrejas que era, menos um local sagrado de culto e oração que um centro associativo exterior e integrador das famílias e das diversas camadas da população. M. L. Moreira. Livros de Viagem..., cit., p. 59.

${ }^{132}$ Sobre a vida doméstica da Colônia vide várias contribuições em L. M. Souza (org.) História da vida privada no Brasil..., cit; e R. Azzi. A vida religiosa feminina no Brasil. In: R. Azzi. (org). A vida religiosa no Brasil..., cit.

${ }^{133}$ H. Koster. Viagens ao nordeste do Brasil..., cit . p. 47-48.
} 
intentos. E assim se ressuscitou e multiplicou um misto de religiosidade divertimento, algo parecido com as nossas festas religiosas de aldeia dos tempos antigos." 134

Temos, assim, mais um exemplo de inter-relação entre os divertimentos e os atos religiosos, possuindo aqui aspecto positivo com relação à diminuição da reclusão das mulheres, porém de suposto atraso quanto aos hábitos católicos. Lugar comum nas narrativas de viagem, o retraimento das mulheres foi aspecto também notado por Debret na sua chegada ao Brasil, em 1816. Ao percorrer a cidade do Rio de Janeiro ficavam os franceses, segundo ele, estranhamente impressionados com o fato de não avistarem nenhuma senhora, tendo que esperar até o dia de festa, quando tinham a chance de observá-las nas igrejas. ${ }^{135}$ Ainda que quase nunca indicada, há clara contradição entre a falta de meios de divertimento das cidades da América portuguesa, geralmente apontadas pelos viajantes, e as festas religiosas, sem que fossem consideradas como eventos voltados ao lazer e interação da vida social. ${ }^{136}$

Para além dos aspectos religiosos, as aparições públicas e cortejos com a presença da Família Real e sua Corte também exerceram papel influenciador na vida dos luso americano, a partir de 1808. A presença do Príncipe disseminou a organização de eventos públicos na colônia, retomando a imponência da realeza que, após deixar sua sede europeia, deparou-se com um ambiente diverso dos espaços palacianos requintados de outrora. Uma transformação sensível se fez sentir tanto para a Corte recém-chegada diante de um cenário tropical, que implicou numa readaptação de hábitos dos portugueses europeus, como também para os portugueses estabelecidos no Brasil, especialmente a elite econômica do Rio de Janeiro. Algumas transformações advieram no sentido de "europeização" das maneiras, até mesmo para os grupos sociais menos abastados, e também para os escravos: as festas promovidas nos aniversários, casamentos, nascimentos ou outros acontecimentos relacionados à Corte, mostravam-se oportunidades de divertimento para os habitantes, aproximando, ainda que simbolicamente, as classes sociais dentro de um mesmo contexto festivo, ensinando ou reafirmando o respeito ao soberano ${ }^{137}$, esboçando um tipo de identidade, a do súdito.

\footnotetext{
${ }^{134}$ J. Luccock. Notas sobre o Rio de Janeiro... cit., p. 165.

${ }^{135}$ J. B. Debret. Viagem pitoresca e histórica ao Brasli..., cit. p. 182.

${ }^{136}$ A. T. Filho. A arquitetura da alteridade..., cit., p.. 232.

${ }^{137}$ Jurandir Malerba. A corte no exílio: civilização e poder no Brasil às vésperas da Independência (18081821). São Paulo: Companhia das Letras, 2000..; Maria Beatriz Nizza da Silva. Cultura e Sociedade no
} 
Fato anunciado por toda a província de Minas, Saint-Hilaire escreveu que a coroação do D. João como rei de Portugal e do Brasil, em 1818, foi comemorada em Vila do Príncipe como "notável acontecimento"; durante todo o dia da comemoração ouviam-se folguedos e bombas, e no fim da tarde todas as casas haviam sido iluminadas para a ocasião, na qual também os negros tiveram lugar, dançando por toda a noite de festejo. ${ }^{138}$ A própria chegada da Família Real ao Rio de Janeiro mostrou-se oportunidade de um refinamento no trato e mudança de ritmo na vida dos habitantes da cidade, que presenciaram a chegada de um príncipe como um fato histórico a ser lembrado constantemente. A própria hierarquia social, insígnias e símbolos, promovidos pela procissão realizada pela chegada da Corte constituíam elementos visuais, sonoros, ou mesmo olfativos que colaboraram para contemplação da representação pública da corte, de certo modo destinada a impressionar. ${ }^{139}$

Thomas O'Neil, primeiro-tenente dos fuzileiros a bordo do London, nau do almirante-de-esquerda Sidney Smith que escoltou a Família Real até a colônia, a primeira de muitas ocasiões em que cerimônias voltadas à presença da realeza no Brasil seriam concretizadas, não deixou de mencionar sua visão da chegada, expressada como uma situação dolorosa, segundo ele, e que despertava o mais alto grau de solidariedade por parte dos súditos:

"Nesse dia, sob uma salva real das naus e das baterias, toda a Família Real desembarcou. Para isso, o chão foi coberto por um veludo carmesim, e um soberbo pálio era sustentado por quatro oficiais; Sua Majestade estava perfeitamente sereno e, com graciosa dignidade, deu atenção a seus zelosos súditos, enquanto lágrimas orvalhavam copiosamente suas faces idosas [...] todas [as] emoções chegaram ao mais alto grau, pois não há alma sensível que veja com indiferença um príncipe benevolente e afável com a mãe idosa, a esposa amada e cinco filhos pequenos, compelidos a deixar seus domínios herdados, legítimos, e obrigados a buscar refúgio numa parte distante do globo quase totalmente isolada do continente europeu!"140

Rio de Janeiro (1808-1821).2 ed. São Paulo: Ed. nacional, 1978.; Maria Eurydice de Barros Ribeiro. Os símbolos do poder: cerimônias e imagens do Estado monárquico no Brasil. Brasília: Editora Universidade de Brasília, 1995.

${ }^{138}$ A. Saint-Hilaire. Viagem pelas províncias do Rio..., cit., .p. 295-296.

${ }^{139}$ M. B. N. Silva. Cultura e Sociedade... cit.,p. 59-60.

${ }^{140}$ Thomas O 'Neil. A vinda da Família Real Portuguesa para o Brasil. Trad. Ruth Sylvia de Miranda Salles. José Olympo: Rio de Janeiro, 2007. p. 73. 
Se envolvida por sentimento de benevolência estava a descrição feita por O’Neil sobre a chegada da realeza, pouco amistosas eram as observações de Luccock no que se refere a eventos festivos da Família Real. A pouca infraestrutura que a colônia dispunha para esses eventos foi ilustrada pelo viajante na descrição de um aniversário da Rainha, poucos meses após a chegada da Corte ao Brasil, quando "só apareceram seis carros à festa, todos eles abertos, de duas rodas, puxados por um par de mulas miseráveis e conduzidos por negros imundos." Assim, segundo ele, ter-se-ia uma ideia do estado de inferioridade da colônia com relação à metrópole, fosse com relação às artes ou às conveniências da vida. ${ }^{141} \mathrm{~A}$ impressão de penúria dos viajantes nos momentos solenes é frequentemente descrita nas narrativas, que enxergavam na Corte migrada uma imagem do suposto estado de inferioridade do país.

O fato da instalação da Corte no Brasil ter influenciado a mudança de hábitos dos colonos e passado a estimular uma nova forma de conduta social, inserida entre a curiosidade dos vassalos da rainha quanto à nova moda e a necessidade de transformação do espaço com a presença da Corte, exerceu importância no desenvolvimento da nova sede do governo português e influenciou de forma contundente as descrições dos habitantes e a construção de uma imagem do Brasil. Esta visão de espelho invertido conduziu não só a descrições do dia-a-dia da colônia, mas também à formação de um estereótipo dos habitantes do Brasil que os vinculava às expressões identitárias a depender de variáveis específicas a cada viajante.

É notório nos relatos que a intenção de promover transformações no espaço físico por meio de explorações dos recursos naturais, assim como as observações sobre a moral e os melhoramentos necessários neste quesito, constituiu para os viajantes um aspecto importante na formação de um Império, sendo este desenvolvimento claramente voltado às referências de uma cultura de produção pautada pela ideia de máximo aproveitamento dos potenciais econômicos que o país pudesse oferecer.

Do ponto de vista de sociedades cujas formas socioeconômicas seriam supostamente mais desenvolvidas historicamente do que a encontrada no Brasil no século XIX, os viajantes viam com atraso a sociedade escravista estabelecida aqui, mas, tal estágio de desenvolvimento era visto também como transitório, tendo o país

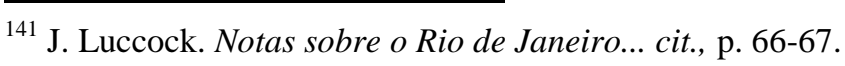


progredido muito com a transferência da corte e o livre-comércio. ${ }^{142}$ De acordo com a historiadora Elizabeth Mendes, que entendeu serem os relatos essencialmente a reflexão sobre a redefinição das relações da sociedade escravista do Brasil com o mercado mundial, os viajantes identificavam-se com os proprietários apesar de suas críticas a eles, "porque estes constituíam uma classe historicamente necessária”, por entenderam que o "progresso" só poderia ser promovido por aqueles que detivessem terras, meios de produção, capitais e a principal parte da riqueza da sociedade luso americana: os escravos. ${ }^{143}$ Assim, independente dos critérios que levariam às depreciações sobre a escravidão, alguns ressalvas surgiam nas digressões dos viajantes. Uma delas está no relato de Saint-Hilaire, que para ser justo, segundo ele, deveria fazer concessões aos partidários da escravidão, apesar dos infortúnios que enxergava neste sistema. Para ele, o negro que caia nas mãos de um senhor bom e sinceramente cristão era mais feliz do que a maioria dos camponeses de algumas províncias da França: tralhavam menos, não tinham inquietações, a fome e a miséria não os atormentavam constantemente. No entanto, acrescentava que não era menos verdade que o escravo corria maiores chances de miséria do que de felicidade, já que havia senhores desumanos em maior número que os bons. ${ }^{144}$ Tollenare também observava que o estrangeiro que desembarcava não poderia se furtar do sentimento penoso que a escravidão causava à primeira vista, mas considerava também que o aspecto geral não apresentava "nem prantos, nem gritos, nem desespero." 145

As advertências que viajantes faziam sobre os meios de produção inseriam no espaço físico formas de se aproveitar os recursos naturais a favor do progresso que, se somadas à maior instrução da população, galgariam degraus importantes para Portugal e para o Brasil nesse momento de crise peninsular. Ainda de acordo com Mendes, as mudanças que propunham, ao menos nos casos dos viajantes capitalistas, não representavam uma mudança radical na natureza econômica que movia o Brasil, que continuaria a ser mercantil e, consequentemente, a valorizar o capital. ${ }^{146} \mathrm{E}$ para os naturalistas, a causa dos infortúnios da escravidão seriam amenizadas com uma conduta dita cristã para com os escravos, como observamos em Saint-Hilaire. No entanto, a

142 Elizabeth de Camargo Mendes. Os viajantes do Brasil: 1808-1822. Dissertação (mestrado em História). São Paulo. USP, 1981., p. 92.; Doyle Cole Libby. Transformação e trabalho em uma economia escravista. Minas Gerais no século XIX. São Paulo: Brasiliense, 1998.

${ }^{143}$ E. C. Mendes. Os viajantes do Brasil..., cit. p. 95.

${ }^{144}$ A. Saint-Hilaire. Viagem pelas províncias do Rio..., cit., .p.101-102

${ }^{145}$ L. F. de Tollenare. Notas dominicais tomadas durante uma viagem em Portugal e ao Brasil em 1816, 1817 e 1818. Progresso: São Paulo/ Salvador, 1956. p. 23.

${ }^{146}$ E. C. Mendes. Os viajantes do Brasil..., cit. p. 96. 
maneira de encarar o trabalho dos habitantes do Brasil em viajantes como Luccock, por exemplo, que mantinha interação próxima com a classe trabalhadora, relativiza a posição isenta ao trabalho escravo que a autora coloca com relação ao desenvolvimento das forças produtivas. Segundo aquele viajante, a "loucura" dos homens brancos consistia em considerarem-se fidalgos demais para trabalhar em público, degradando-se se fossem vistos carregando suas ferramentas de ofício pelas ruas, predominando em todas as classes da sociedade luso americana "o orgulho tolo e a presunção formalizada" ${ }^{\prime 147}$.

Em visita ao Tijuco em 1809, principal distrito diamantino da colônia, Mawe apontava as possibilidades de melhorias em benéfico do comércio, aconselhando o governo a promover no Brasil a exploração dos rios, a fim de se estabelecerem comunicações entre os polos produtores do país. Ele argumentava que facilmente se poderia conceber a vantagem que resultaria, para os habitantes, da abertura da navegação: a produção teria saída mais pronta e todo o território lucraria com as melhorias. A vantagem em ter à disposição uma natureza abundante levava Mawe, e outros viajantes oitocentistas, a enfatizarem a necessidade de obras por todo o território. Porém, insatisfeito com os meios de produção que encontrou no Brasil, Mawe observava nos habitantes sentimento de aversão pelo progresso, estando as coisas condenadas, segundo ele, a seguir a mesma rotina, "entregues a homens que tremem à perspectiva de temporário aumento de trabalho, mesmo quando se lhes promete lucro permanente". A inação, mesmo acompanhada de aborrecimentos, era aqui preferível, segundo o viajante, ao trabalho seguido de prazeres. ${ }^{148}$

A maneira pela qual os habitantes do Brasil colocavam em prática qualquer que fosse o oficio, era geralmente interpretada como hábitos falhos, incompatíveis com a maneira usualmente utilizada nos países de origem dos viajantes. Ao descrever a rotina dos mercadores do Rio de Janeiro, por exemplo, Luccock observava que o trabalho lhes tomava apenas duas ou três horas do dia, sobrando-lhes tempo bastante para que “pudessem empregar a elevar-se mais próximo do nível dos negociantes de melhor casta de outros países"; mas o desinteresse pelo conhecimento, até mesmo pelo próprio oficio, seria um traço degradante do caráter dos habitantes do Brasil, constantemente observado pela maioria dos viajantes. Mas havia aqueles que de certa forma enalteciam determinados ofícios e o modo como eram colocados em prática no Brasil. Entre eles

\footnotetext{
${ }^{147}$ J. Luccock. Notas sobre o Rio de Janeiro... cit.,p. 71-73

${ }^{148}$ J. Mawe. Viagem ao interior do Brasil.., cit., p. 112-113.
} 
estava o francês Ferdinand Denis, que dizia em nada ser parecido a classe dos operários "brasileiros", termo melhor analisado no próximo capítulo, com a grupo dos operários europeus, principalmente se aqueles pertencessem à raça branca. Dizia que acostumados a ter negros às suas ordens, "e transferindo para eles o encargo das obras mais grosseiras", conheciam tão bem a dignidade de mestre que não se apresentavam em casa de quem os chamasse "senão vestido de cascara preta e algumas vezes com chapéu de três bicos". Assim como Debret, Denis ressaltava especialmente a função dos barbeiros, citando e concordando com aquele, que dizia poder encontrar na mesma pessoa "um barbeiro, mestre com sua navalha, um cabeleireiro seguro de seus arranjos, um cirurgião familiarizado e um homem perito em aplicar sanguessugas" 149

As imputações feitas pelos viajantes ao caráter dos luso americanos geralmente estão acompanhadas de um traço de "ingenuidade", transformada por eles, cada um à sua maneira, em características positivas ou negativas sobre os habitantes. No relato sobre sua breve permanência no Brasil, O’Neil privilegia as “características originais da autêntica inocência". São políticos os motivos apontados por ele que levaram os habitantes a constituir esta índole ingênua, na medida em que os vice-reis, "absolutos em seu modo de governar", sempre teriam impedido os habitantes de um intercâmbio com outras nações. ${ }^{150}$ Este traço será, de certa maneira, o fio condutor das observações feitas por ele, ao passo que a abertura dos portos teria constituído o pontapé inicial que a colônia de Portugal necessitava para caminhar rumo ao progresso.

O caráter das mulheres, a quem O’Neil garantiu espaço nas páginas de seu sucinto relato, também compõe este traço de naturalidade de uma sociedade supostamente apartada da Europa civilizada, considerando-as encantadoras, elegantemente bem formadas e recatadamente sedutoras. Sua análise, tal qual um britânico, sempre pronto a dar estímulos a uma população ainda imersa em desafetação com relação aos modos pretensamente civilizados, ainda que conservasse um ar de delicadeza nas descrições, lamentava que tais mulheres, "feitas para transmitir as mais puras sensações à nossa natureza, não tenham mente igualmente cultivadas". Sua inocência, típica da terra, muito menos refreada, segundo ele, do que em nações com intercâmbio maior com outras, levaria uma pessoa que desconhecesse totalmente os costumes, a supor uma

\footnotetext{
${ }^{149}$ Ferdinand Denis. Brasil. Trad. João Etienne Filho e Malta Lima. Belo Horizonte/São Paulo: Itatiaia/ EDUSP, 1980.p. 134.

${ }^{150}$ T. O 'Neil. A vinda da Família Real Portuguesa para o Brasil.., cit., p. 81.
} 
licenciosidade por parte delas, quando na verdade não passava da ingenuidade mantida pelos habitantes devido a seu isolamento. ${ }^{151}$

Ao passo que em O’Neil este traço está colocado como consequência do modo de governo aplicado à colônia portuguesa até o momento da translação do Príncipe Regente para cá, outros viajantes, que diferentemente deste passaram mais tempo entre os colonos, tendo suas observações direcionadas a outros fatores, tais como o motivo da viagem, profissão e, claro, o caráter pessoal incutido em cada uma das narrativas, foram menos condescendentes para com os habitantes e para o estado em que se encontravam, mostrando-se mais propensos às críticas e transformando a "inocência" em características negativas, na construção do caráter dos habitantes.

Vindo do sul, ao visitar cidades como Buenos Aires e Montevidéu, Mawe assinalava distinções nos aspectos gerais e nas maneiras dos habitantes do Brasil, tidos como superiores com relação aos que havia deixado. Afirmava, numa visita a São Paulo, que nas festas públicas e nos bailes sempre encontrava novidade e prazer: novidade, porque eram muito melhor recebidos do que nas colônias espanholas, e prazer, por estar num meio mais requintado e cortês. ${ }^{152}$ No entanto, o nível de instrução, de modo geral, dos homens educados garantia na opinião dele menos uma conversa instrutiva do que animada. ${ }^{153}$ Apesar de algumas considerações positivas, Mawe toma os habitantes do Brasil por "homens degenerados", frequentemente devido à suposta propensão destes à inação e indigência, agravadas pela falta de instrução da população.

Ao longo da narrativa, e apesar do aspecto comparativo com os hispanoamericanos ter causado impacto positivo com relação aos habitantes da América portuguesa, é apontado por ele de forma acentuada o espírito à desocupação dos habitantes do Brasil. Este é um caráter negativo geralmente lançado pelos estrangeiros na construção de uma imagem dos habitantes da América, ganhando corpo ao longo da narrativa deste viajante, principalmente em referência aos residentes dos distritos mineradores, como Vila Rica, onde a "educação, os hábitos, preconceitos hereditários" os tornariam inaptos à vida ativa e, sempre entregues à perspectiva de enriquecer subitamente, imaginavam estar "isentos da lei universal da natureza, que obriga o homem a ganhar o pão com o suor de seu rosto". Esta é uma degeneração que constitui

\footnotetext{
151 Ibidem, p. 91-92.

152 J. Mawe. Viagem ao interior do Brasil.., cit., p. 71.

${ }^{153}$ Esta análise é feita com relação ao Rio de Janeiro, mas pode ser apreendida ao longo da narrativa em diversos outros momentos, compondo o traço dos habitantes do Brasil neste e nos demais viajantes analisados.
} 
o traço característico da maior parte dos descendentes dos primeiros colonos, na opinião de Mawe, ao passo que todas as indústrias estavam nas mãos de negros ou mulatos que, pelo simples fato de exercerem a grande maioria das atividades, pareciam exceder em inteligência por fazerem uso do trabalho. ${ }^{154}$

Mesmo o exemplo de labor oriundo da convivência entre filhos dos escravos e dos senhores, tornando-se amigos de infância até que a familiaridade estabelecida fosse abolida na idade em que um deveria dar ordens e o outro obedecê-las ${ }^{155}$, constituía na sua visão incentivo ao trabalho produtivo nos habitantes do Brasil. De acordo com Mawe,

“Acredita-se com razão que os rapazes de uma família [...] devem ser criados na ociosidade, ensina-se-lhes apenas a ler e a escrever [...] Educados na pobreza e no orgulho, aprenderam a considerar servis todos os trabalhos, e o único que conhecem é geralmente tão pouco produtivo, que se torna para eles odioso [...] Toda ocupação útil, toda a comodidade de vida são abandonadas para se ir à cata de tesouros ocultos, que, se encontrados, raramente são usufruídos de maneira proveitosa, e antes servem para aumentar a preguiça de seus possuidores."156

A "ingenuidade", traduzida ou pela perspectiva da inocência devido ao estado recluso da sociedade, ou pela ignorância e repulsa pelo trabalho e instrução, teria tido reflexos, direta ou indiretamente, em todos os meandros da sociedade luso americana, na visão dos viajantes, logo, na definição de uma identidade. Mesmo com o privilégio de viver num dos mais belos climas do mundo e num país que oferecia os meios naturais para se alcançar o progresso, de modo geral condições profundamente propícias à realização de atividades rentáveis, segundo os viajantes oitocentistas, os habitantes do Brasil prefeririam à miséria, mesmo vivendo num estado de escassez completa, tamanha era a falta de conhecimento e instrução. Uma visão clara dessa postura pode ser identificada no relato de Saint-Hilaire sobre as particularidades do interior do Brasil com relação às encontradas na Europa:

\footnotetext{
${ }^{154}$ Ibidem, p. 129.

155 Ibidem, p. 72.

${ }^{156}$ Ibidem , p. 241.
} 
Em nossas regiões, povoadas a tantos séculos, tudo está impregnado de variedade. Aqui um monumento histórico, ali uma manufatura, acolá um palácio em que tudo respira magnificência; a menor povoação pode apresentar tradição, e tem-se, por toda parte, a imagem do trabalho, do movimento e da vida. No interior da América, pelo contrário, reinam o silêncio e a uniformidade. O naturalista encontra, sem dúvida, grande variedade nas minúcias; mas o viajante que se contente em observar o conjunto, sucumbiria ao peso do tédio. ${ }^{157}$

Não se podia viajar pelo Brasil esperando encontrar caminhos traçados por arte, segundo o viajante, nem campos cultivados, e as ocupações científicas perdiam seu encanto, porque quem se entregava a elas não podia se comunicar com ninguém que as entendia. $^{158}$

Também com relação aos supostos melhoramentos, Koster observava que por muitos anos o Brasil não tinha recebido qualquer incentivo na área agrícola, a não ser pela presença da Corte, e mesmo após sua instalação no país, as inovações foram feitas muito devagar e com imensas dificuldades. Ao contrário de Luccock e Mawe, que atribuem o atraso à aversão ao trabalho e à indulgencia, característica para eles dos habitantes do Brasil, em concordância com a ideia de inocência dos habitantes, Koster atenta para o fato de ser

“inteiramente debalde esperar mudança rápida do sistema entre homens que nem sequer ouviram falar que existiam outros agricultores além deles próprios; que ficaram admirados ao saber que não era o Brasil o único país no qual se produzia açúcar; que não sabem, ou pelo menos até pouco tempo não sabiam, que havia outra nação afora deles; que imaginavam ser Portugal o senhor de tudo quanto valia a pena possuir-se no mundo, na realidade, cuja ignorância era extrema." 159

Para ele, seguindo o mesmo sistema agrícola dos pais, os produtores do Brasil, sem nenhum desejo de progresso, mantinham-se na ignorância de que poderiam fazer

\footnotetext{
${ }^{157}$ A. Saint-Hilaire. Viagem pelas províncias..., cit. p. 223

${ }^{158}$ Ibidem, 224.

${ }^{159}$ H. Koster. Viagens ao nordeste..., cit., p. 421.
} 
qualquer melhoramento, também no sentido de falta de conhecimentos que os habilitassem às melhorias tidas por necessárias.

Com uma predisposição maior aos traços positivos na descrição dos habitantes, Debret, ao mencionar os costumes dos "brasileiro civilizado", termo recorrente nos viajantes e que será abordado mais detalhadamente no segundo capítulo, apontava com justeza, que os viajantes que percorriam o Novo Mundo falavam a respeito dele como o habitante "mais cortes e afável da América do Sul". Tendo sua independência reconhecida pelas potências europeias, tomando o direito de gerir seus próprios interesses, o "brasileiro" conservava uma atitude tranquila em comparação às comoções populares que assolavam a América espanhola, assentando a glória da pátria numa legislação moderna que a experiência sensata fez adotar. ${ }^{160} \mathrm{O}$ ambiente político instável das primeiras décadas do século XIX na América hispânica teria dado aos viajantes, enquanto observadores dos avanços da América portuguesa neste período, a conveniência de estabelecer comparações do estado político entre ambas. Enquanto na primeira, o exemplo era de incertezas e limitações no estabelecimento de um governo sensato, na segunda prevalecia a calmaria devido às cautelas empreendidas por um governo ponderado em não se deixar envolver pelas convulsões da região vizinha. ${ }^{161}$

Publicando sua obra em momento posterior aos demais viajantes, o artista tendência sua análise ao progresso político advindo com a independência, mas também apontava traços que compõem lugar comum nas narrativas de viagem, como progresso e a desafetação com relação aos percalços vividos pelos vizinhos hispano-americanos. As mudanças vivenciadas na América portuguesa, desde a época em que o país estava sujeito aos vice-reis até momento de revoluções no império, teriam permitido também, na visão de Denis, que todos os homens, desde os senhores de engenho até o mineiro condutor de caravanas, modificassem os costumes primitivos. ${ }^{162}$

\footnotetext{
${ }^{160}$ J. B. Debret. Viagem pitoresca..., cit. p.140-141.

${ }^{161}$ Crítica à tradicional visão do Brasil como uma região pacífica em contraste com o restante da América ibérica na época em que vivia as revoluções de independência pode ser vista em João Paulo G. Pimenta. Resistiendo a la Revolucion: El Brasil in 1810. Historia y politica, v. 24, 2010, p. 170. Abordagens historiográficas mais recentes que propõem análises dos processos de independência na América ibérica como parte de uma mesma conjuntura podem ser visto em J. P. G. Pimenta. O Brasil e a América Espanhola. Tese de Doutorado, USP-FFLCH, São Paulo, 2003; Camila Farah Ferreira Alves. Na América dos impérios: a leitura do Brasil pela imprensa periódica da Nova Espanha no contexto das independências (1808-1822). Dissertação de Mestrado, USP-FFLCH, São Paulo, 2014; Maria Júlia Manão Pires Neves. O Peru lê o Brasil: o mundo luso americano na imprensa e na política peruana (1808-1822). Dissertação de Mestrado. USP-FFLCH, São Paulo, 2014.

${ }^{162}$ F. Denis. Brasil..., cit. p. 135.
} 
O fato é que os traços de caráter dos habitantes do Brasil, independentemente de como a sua suposta ingenuidade é tratada pelos viajantes, foram na maioria dos relatos relacionados à forma de produção, abarcando neste aspecto a predileção pelo ócio, o desinteresse pelo conhecimento, a falta de instrução, o orgulho, ou ainda a falta de contato com nações tidas evoluídas que teria mantido o atraso da população, e às maneiras e costumes abarcando as práticas religiosas e/ou sociais. Todas estas perspectivas da vida social na colônia estavam eivadas de conceitos e julgamentos deslocados do núcleo de referentes nos quais a população do Brasil estava inserida.

O sistema de produção agrícola no Brasil, a principal fonte de renda para a Coroa, depois de declinada em grande parte a produção das jazidas de metais e pedras preciosas, assim como as práticas sociais, foram, portanto, imensamente discutidos por muitos viajantes. Eles observaram as supostas incongruências e o estado da moral e do caráter da população na América portuguesa, contando inúmeros atrasos e prejuízos que a maneira de conduzir as atividades econômicas e o trato social teriam acarretado para o país.

Ainda que as informações veiculadas pelos relatos de viagem envolvam questões de veracidade, o caráter repetitivo das narrativas, que trazem os mesmo personagens e lugares à cena, apresentam características dos locais visitados que oferecem um panorama permeado por elementos de análise úteis na construção de uma imagem dos habitantes do Brasil a partir do olhar estrangeiro. A riqueza de detalhes dos relatos de viagem integra-se numa rede de informação que engendra a construção de uma visão específica a respeito dos habitantes de um mundo considerado, de maneira geral, insípido, semicivilizado, em processo de evolução. O detalhamento contido na literatura de viagem está integrado, no que concerne a este trabalho, portanto, à construção do estereótipo luso americano, ponto de partida para, que, num futuro próximo, as identidades coletivas contidas neste espaço tomassem corpo e assumissem papel definidor na formação da identidade nacional, um dos pilares essenciais para a construção da "nação brasileira" ainda inexistente em inícios do século XIX. Os aspectos peculiares observados por esses agentes históricos, eleitos aqui como importantes definidores de um "caráter nacional” dos habitantes da América portuguesa, nos permitem vislumbrar o Brasil, ou os "Brasis", que estava sendo delineado também através do olhar estrangeiro, dotando as feições dessa porção do império português de particularidades potenciais na formação de uma identidade. 
O próximo capitulo irá analisar como os viajantes interpretaram os episódios políticos de início do século XIX, dos quais muitos foram testemunhas, e a forma como eles relacionaram tais acontecimentos ao surgimento de preocupações e anseios em comum nos "brasileiros", em torno de um conjecturado sentimento de pertencimento ao Brasil, e buscará analisar também como os viajantes elencados nesta pesquisa definiram o "brasileiro" e o integraram em tipos específicos de identidade, ambos os aspectos componentes de uma possível formação da nacionalidade brasileira. 


\section{Capítulo II - Brasil e brasileiros: identidades coletivas no discurso dos viajantes}

\section{1 - A questão nacional e o Estado nos relatos de viagem}

O processo de formação do Estado e da nação brasileira, pautados nos valores e na cultura política de outras nações, pode ser encadeado ao movimento político de início do século XIX que colocou o país num estado de cosmopolitismo nunca antes vivenciado. A presença dos estrangeiros e as suas incursões no cenário luso americano de então são aspectos importantes da construção de uma imagem sobre o Brasil, além da interlocução estabelecida entre os agentes que promoveram a formação do Estado nacional e dos estrangeiros, que analisaram e escreveram sobre uma possível identidade nacional brasileira. Dois marcos cronológicos estabelecidos nesta pesquisa, tanto os acontecimentos políticos de 1808 quanto as ações independentistas de 1822, assim como outros acontecimentos deste período, foram pensados pelos viajantes estrangeiros nela analisados como episódios políticos importantes que teriam despertado nos "brasileiros" sentimentos de tipo nacional.

Alguns aspectos deste processo surgem com frequência na interpretação da formação nacional no Brasil, especialmente no espaço de realizações históricas, para onde foi transplantado o aparelho de Estado europeu ${ }^{163}$ e onde se configurou uma forma de governo complexa, antes apartada de proximidade com sua metrópole, e que a partir do século XIX apontava senão modificações em longo prazo, ao menos uma fissura nas formas tradicionais de administração colonial e nas relações entre as partes até então constitutivas do império. ${ }^{164} \mathrm{Um}$ desses aspectos é a forma como se constituiu uma nação num espaço mesclado, tanto no caráter racial quanto no social, onde os homens de cor, os nascidos no país, os brancos e os "filhos do reino" disputavam e galgavam prestígios políticos nesse ambiente de múltiplas feições e, consequentemente, difíceis denominações enquanto nação. Bem notado por Schwartz, o Brasil enquanto ideia foi com frequência mais um projeto do que uma realidade, "às vezes geográfica, às vezes nacional ou até social”, tendo como método de estratégia discursiva a definição de um

\footnotetext{
${ }^{163}$ A respeito dos projetos cogitados por Portugal com relação à transferência da Corte para a América, ver Maria de Lourdes V. Lyra. A utopia do poderoso império. Portugal e Brasil: bastidores da política 1798-1822. Rio de Janeiro: Sette Letras, 1994.

${ }^{164}$ Para uma apreciação geral das estruturas de poder em Portugal no Antigo Regime, ver Antonio Manuel Hespanha (coord.) História de Portugal. O Antigo Regime (1620-1807). Lisboa: Estampa, 1998.; Charles Ralph Boxer. O império colonial português (1415-1825). Lisboa: Edições 70, 1981.
} 
Brasil "verdadeiro" em oposição a um Brasil do momento. Segundo ele, a habilidade dos historiadores em recapturar os conceitos de Brasil tem sido limitada pelo fato de que o que conhecemos como mentalidade dos habitantes tem origem no pequeno contingente da elite, "quase sempre homens, a grande maioria deles educados em Portugal", excluídos especialmente os indivíduos de origem africana, indígena ou mestiça. ${ }^{165}$

Os viajantes estrangeiros ainda que indivíduos oriundos da elite intelectual e econômica de outros países representaram com desenvoltura os estratos da sociedade lusa americana, visão de algum modo devolvida a essa mesma realidade, não excluindo de suas análises aqueles indivíduos que não compunham o grupo social mencionado por Schwartz. Empreenderam suas observações também com relação ao mestiço, ora integrando-o ao corpo social, ora segregando-o a uma posição inferior ao "brasileiro" ou ao "português", almejando compreender os rumos da formação nacional do Brasil.

As contribuições em torno da formação nacional foram acompanhadas nos relatos analisados de eventos históricos que recebiam significados nem sempre similares, mas que acabaram por introduzir conceitos para a formação de imagens sobre o Brasil até aquele momento inéditos, tais como "formação de um sentimento de patriotismo, de nacionalidade, de um espírito brasileiro, de um caráter nacional, de unanimidade de sentimentos, de unidade territorial, de um sentimento de independência, de opinião pública, de uma sociedade coesa." "166 A oferta destes termos e conceitos que atribuíam ao pertencimento ao Brasil algum significado foi com frequência tópico dos viajantes, exercendo de alguma forma contribuição na forma de se pensar os parâmetros de uma nação, ainda inexistente. $\mathrm{Na}$ estrutura da monarquia portuguesa, em conformidade com as formas coloniais aplicadas ao Brasil e às diversas identidades coletivas coexistentes neste cenário ambivalente, interagiam diversas manifestações de pertencimento dos indivíduos na metrópole e colônia, integrantes de um conjunto intricado e dinâmico, relacionado à crise política iniciada no século XVIII e conformada na independência política do Brasil. Esta análise privilegia a mecânica do amplo processo de formação da nação, tendo como particularidade os contornos identitários dos habitantes das

\footnotetext{
165 Stuart B. Schwarz. "Gente da terra braziliense da nasção". Pensando o Brasil: a construção de um povo. In: Carlos Guilherme Mota (org.). Viagem Incompleta. A experiência brasileira. 2 ed. São Paulo: Senac, 2000. p. 105-106.

${ }^{166}$ Karen Macknow Lisboa. Olhares estrangeiros sobre o Brasil do século XIX. in: Carlos Guilherme Mota (org.). Viagem Incompleta..., cit. p. 278.
} 
possessões portuguesa na América ou de pessoas que, de diferentes modos, passaram a ser reconhecidos como vinculados politicamente a ela.

A identificação dos habitantes da América portuguesa feita pelos viajantes como parte de uma coletividade, que raramente os próprios indivíduos analisados julgariam existir, está posta sob diversos pontos de vista. Isto porque o considerável interesse que a América exerceu no mundo nas primeiras décadas do século XIX e que foi intensificado com a abertura de seus portos ao comércio, em 1808, possibilitou aos estrangeiros o desenvolvimento de tais ideias, concretizado por meio dos relatos de viagem. Este é um dado significativo na medida em que a produção deste gênero da literatura era de grande interesse e circulação na Europa nesse período, exercendo influência a respeito do que era escrito sobre o Brasil. ${ }^{167}$

No caso da América portuguesa, a formação da nação deve ser analisada a partir das situações vivenciadas não apenas no plano das ideias: as mudanças ocorridas a partir da vinda da Família Real ao Brasil e as conjunturas políticas, sociais e econômicas que se desenrolaram com este episódio inédito, com grandes consequências para a dinâmica do império português ${ }^{168}$, constituem um manancial de referenciais concretos importantes na formação de identidades coletivas que viriam a se politizar $^{169} \mathrm{e}$ constituir bases para uma futura formação nacional. Portanto, a nação necessita de análises concretas, enquanto categoria histórica passível de transformação, tornando-se necessária visão clara do mundo de que se trata e inferindo o momento específico no qual sua manifestação é contemplada, a fim de se evitar riscos teleológicos. ${ }^{170}$

\footnotetext{
${ }^{167}$ K. M. Lisboa. Os olhos estrangeiros..., cit. p. 268. Outras análise dos viajantes e a construção de uma imagem sobre o Brasil pode ser vista também em Flora Medeiros Lahuerta. Viajantes e a construção de uma ideia de Brasil no ocaso da colonização (1808-1822). Revista eletronica de geografias y ciências sociales. vol. X, n. 218 (64), 2006.; Wilma Peres Costa. Viajantes europeus e o escrever da nação brasileira. In: Marco A. Pamplona \& Don Doyle (orgs.) Nacionalismos no novo mundo - a formação de Estados-nação no século XIX. Rio de Janeiro: Record, 2008.

${ }^{168}$ A bibliografia a este respeito é extensa. Alguns exemplos são: Jorge Pedreira e Fernando Dores Costa. D. João VI. Um príncipe em dois continentes. São Paulo: Companhia das Letras, 2008. (Especificamente os capítulos "O Príncipe do Brasil (1808-14)" e "Novo Reino para Novo Rei (1815-21)"). Lilian Mortiz Shwarzc. D. João carioca: a corte portuguesa chega ao Brasil (1808-22). São Paulo: Companhia das Letras, 2008. V. Alexandre. Os sentidos do império: questão nacional e questão colonial na crise do Antigo Regime português. Porto: Afrontamentos, 1993.; Andrea Slemian \& João Pauo G. Pimenta. $A$ corte e o mundo. Uma história do ano em que a família real portuguesa chegou ao Brasil. São Paulo: Alameda, 2008.; Oliveira Viana. Dom João VI no Brasil, Rio de Janeiro, Topbooks, 1996. p. 335-356.

${ }^{169}$ István Jancsó \& João Paulo G. Pimenta. Peças de um mosaico (ou apontamentos para o estudo da emergência da identidade nacional brasileira). Revista de História das ideias (Coimbra), v. 21, 2000, p. 389-440. Ver também J. P. G. Pimenta. Portugueses, americanos, brasileiros: identidades políticas na crise do Antigo Regime luso americano. AlmanackBraziliense (online), São Paulo, v. 3, 2006.

${ }^{170}$ Pierre Villar. Reflexiones sobre los fundamentos de las estructuras nacionales. In: Hidalgos, amotinados y guerrilleros: pueblos y poderes en la historia de España. Barcelona: Grijalbo, 1982. p. 306.
} 
A vinda da Corte de Portugal figura entre os viajantes analisados como o acontecimento que de fato teria começado a tirar o Brasil do estado que até então se designava estagnado. Mesmo as breves considerações de Thomas O’Neil sobre este acontecimento apontaram para esta condição da colônia portuguesa. A caminho do Brasil em 12 de janeiro de 1808, O’neil justificava o valor de seu depoimento enquanto testemunha ocular dos fatos que se desdobraram na translação da corte ao Brasil. No entanto, o tenente irlandês teria desembarcado no Rio de Janeiro em 29 de fevereiro, bastante tempo depois da Família Real, não acompanhando o príncipe nos momentos iniciais após o desembarque. Ainda assim, o viajante revelava a ideia de humanitarismo dos habitantes, por exemplo, ao receberem "de braços abertos os ilustres fugitivos", numa região do mundo em que se era levado a acreditar que estaria num estado quase selvagem, devido ao isolamento com relação a outras nações. ${ }^{171}$

O início dos oitocentos constituía parte tão significativa também das impressões de Mawe, que viajou pelo Brasil no intervalo de 1807 a 1811, levando-o mesmo a considerar o período em que visitou a capital como a "era política" nos acontecimentos do Brasil. ${ }^{172}$ As notícias de que o Príncipe Regente e sua Corte haviam deixado Portugal sob escolta britânica teria sido recebida com exultação pela maior parte dos "brasilians", que se consolavam em receber o Príncipe a quem todos eram leais, considerando a partir de então como estabelecido o "Brazilian Empire". ${ }^{173}$

E dentre as decisões mais urgentes e decisivas a serem tomada diante da nova condição política do Brasil a partir de 1808, estava a regulamentação do comércio externo, que restabeleceria a dinâmica do governo português alterada pelas guerras napoleônicas (1803-1815). ${ }^{174}$ As medidas que articulassem a economia luso americana

\footnotetext{
${ }^{171}$ Thomas O'Neil. A concise and accurate account of the proccedings of the Squadron under the command of Rear Admiral Sir Sydney Smith.... Londres: Barfield, 1810.p. 35-38.

172 John Mawe. Travels in the interior of Brazil, particulary in the gold and diamond districts of that country, by authority of the Prince regent of Portugal; including a voyage to the Rio de la Plata, and an historical sketch of the revolution of Buenos Ayres.London :Longman, 1812. p. 97. Os trechos diretamente relacionados às identidades coletivas identificadas nos relatos serão citados na língua original e, sempre que possível, a partir das primeiras edições das respectivas obras, seguidos da tradução extraídas das edições em português. As traduções apresentadas em nota do relato de Mawe foram extraídas da seguinte edição:John Mawe. Viagem ao interior do Brasil. Trad. Solena Benevides Viana. São Paulo; Belo Horizonte: Edusp; Itatiaia, 1978.

${ }^{173}$ Ibidem, p. 86. "Império brasileiro"

174 A reorganização do comércio e a estabilização econômica do Brasil em face das novas regras comerciais e tratados firmados em 1810 não teria sido motivada pela vinda da Família Real, segundo Iara L. Souza. Para a autora, ainda que a proximidade com o governo central tivesse intensificado o processo no Brasil, as motivações para o rearranjo político-econômico da situação portuguesa no cenário internacional já estariam sendo dadas em finais do século XVIII, com uma série de tensões e transformações sociais. I. L. Souza. A pátria coroada: o Brasil como corpo político autônomo. 17801831. São Paulo: UNESP, 1999. p. 44.
} 
ao cenário internacional teriam o papel de preencher o vazio causado pelo fim de uma das arestas fundamentais do sistema de dominação vigente entre Portugal e Brasil, o pacto colonial. Neste cenário de intensas transformações, os tratados estabelecidos com a Grã-Bretanha faziam desta potência "protetora" a mediadora das relações comerciais portuguesas, inacessíveis aos mercados europeus devido ao bloqueio continental, garantindo-lhe uma posição privilegiada no comércio externo do Brasil. ${ }^{175}$

O Rio de Janeiro como capital de vasto e rico território, possuindo o porto colonial supostamente mais bem localizado no mundo para o comércio geral e gozando, mais do que qualquer outro, de facilidades de intercâmbio com outros continentes, segundo Mawe, somente exigia um governo eficiente que lhe desse prestígio, adquirido ao ser escolhido para residência da Corte de Portugal. ${ }^{176} \mathrm{O}$ viajante associava, assim, as reformas empreendidas pelo príncipe ao bem estar dos súditos, passando a ser adotadas, desde a chegada daquele, medidas que desenvolvessem o gosto pelos conhecimentos úteis. $^{177}$

O fim das restrições coloniais impostas ao Brasil é aspecto, portanto, importante e bastante recorrente em Mawe quando se trata dos melhoramentos acarretados com a presença da Corte. O ponto de vista comercial é algo que no texto do viajante acompanha a construção de uma espécie de nacionalidade ao apontar a prosperidade que o país poderia alcançar mediante uma sábia administração. A construção de estradas, por exemplo, correspondia às obras de importância do "national point of view"178, e sempre aconselhando ao longo da narrativa que o governo promovesse a exploração dos rios, uma providência de tão alta importância para o país era apresentada por ele como uma das vantagens desse reino. ${ }^{179}$

Koster, que publicou em 1816 o seu relato, também atribuiu a negligência da administração ao Antigo Regime, ao ponto da vinda do Soberano significar para ele a oportunidade de desenvolvimento de atividades por pessoas que esperavam o momento de "despertar" do estado em que se encontravam. Segundo ele, os habitantes do Brasil sentiam a importância de ver o país dar leis à "Mother country" e que o espírito contido pela sujeição aos antigos governos coloniais teve a oportunidade para se expandir. A

\footnotetext{
${ }^{175}$ V. Alexandre. Os sentidos do império..., cit.p. 209-211. A assinatura dos tratados de 1810 realocaria o Império português no sistema internacional, garantindo uma importante "conquista" para o governo britânico, aumentando seus lucros e dinamizando a economia do Brasil. Andrew Porter (org.). The Oxford History of British Empire. Vol III. Oxford/Nova York: Oxford University Press, 1999.

${ }^{176}$ J. Mawe. Travels in the interior..., cit. p. 99.

${ }^{177}$ Ibidem, p. 104-105.

${ }^{178}$ Ibidem, p. 58. "ponto de vista nacional"

${ }^{179}$ Ibidem, p. 241.
} 
necessidade de reformas está no viajante relacionada ao rompimento das restrições às quais o país estava submetido, e a livre comunicação com outras nações seria o meio útil para se atingir benefícios que aos poucos iriam aumentar, ao ponto do Brasil produzir "árvore mais poderosa que o ramo de onde nasceu", ocupando lugar de direito, segundo o viajante, entre as grandes nações do mundo". ${ }^{180}$

Em uma análise do continente americano, Koster dá o panorama geral da situação que levou as colônias inglesas e espanholas a libertarem-se da "mãe-pátria". O sentimento dos primeiros colonizadores na América do norte teria sido o primeiro exemplo de espírito do povo e do governo em superar as inconveniências resultantes de uma libertação para ele prematura, mas que conseguiu adiantamento surpreendente, quase sobrenatural, em riqueza e bem estar, e como consequência, o respeito no quadro das nações. ${ }^{181}$ No entanto, tal conquista não foi alcançada, segundo o viajante, sem anos de miséria e de desolação, experiência naquele momento vivenciada pela América hispânica. ${ }^{182}$ Quanto ao Brasil, as circunstâncias que se apresentavam eram para Koster muito especiais: devido a um governo próprio, o Brasil provavelmente estaria livre dos infortúnios das revoluções, caso predominasse a prudência dos governantes. Segundo o viajante, uma reforma da administração levaria o país a um adiantamento geral, e tais medidas consistiriam em alguns critérios, como a abolição do tráfico de escravos, a tolerância de todas as religiões, a naturalização dos forasteiros e a instituição das assembleias legislativas e das Cortes Gerais. ${ }^{183}$ Em comparação com os Estados Unidos e com a América hispânica, que não escaparam à revolução, o Brasil teria em medidas políticas ponderadas o caminho para alcançar o respeito entre as demais nações do mundo, segundo Koster. A apreciação do viajante visava, portanto, uma transformação profunda de governo. Isto porque, segundo ele, a população havia se acostumado à

\footnotetext{
${ }^{180}$ Henry Koster. Travels in Brazil, by Henry Koster.Londres:Longman, 1816. p.40-41. Os trechos traduzidos foram extraídos da seguinte edição: Viagens ao nordeste do Brasil. "Travels in Brazil". Trad. de Luiz da Câmara Cascudo. São Paulo: Companhia Editora Nacional, 1942. "mãe-pátria"

${ }^{181}$ Obra fundamental para se compreender as diversas interfaces da Revolução americana a partir das grandes linhas historiográficas e o papel que a Revolução exerceu nos rumos políticos das nações emergentes da América Latina pode ser vista em Bernard Bailyn. As origens ideológicas da Revolução Americana. Ed. Ampliada. Trad. Cleide Rapucci. Bauru: EDUSC, 2003.

${ }^{182}$ H. Koster. Travels in Brazil..., cit. 471-472.

${ }^{183}$ Ibidem, p. 472. Sobre a apropriação da história do constitucionalismo às vésperas da Independência, como uma das últimas tentativas de solucionar a crise do antigo sistema colonial é mostrada por Paula Botafogo Carrichio. Redatores no Rio de Janeiro e deputados nas Cortes de Lisboa pela construção da monarquia constitucional portuguesa (1821-1822). Tese (Doutorado). São Paulo, USP-FFLCH, 2011; Márcia R. Berbel. Os apelos nacionais nas Cortes Constituintes de Lisboa (182-1822). In: Jurandir Malerba (org). A independência brasileira: novas dimensões. Rio de Janeiro: FGV, 2006. Cecília Helena L. de Salles. Liberal ou Absolutista. Revista de História da Biblioteca Nacional, Rio de Janeiro, v. 7, n. 74, Nov. 2011.
} 
submissão, e uma mutação administrativa seria muito difícil, a não ser que os prejuízos desta situação o forçassem ao melhoramento. Somente o exemplo de libertação da “mãe-pátria" dado pelas colônias da América do Norte não era suficiente para Brasil, na opinião do viajante, despertar uma nacionalidade, mas os infortúnios das revoluções não precisariam ser o caminho percorrido pelo país.

Dentre os ingleses, talvez seja Luccock o viajante que de modo mais cabal pretendeu enxergar uma espécie de "sentimento nacional" no Brasil em face dos acontecimentos políticos que, aos poucos, o desvincularia de Portugal. O consenso entre alguns viajantes de que a instalação da Família Real no Brasil teria sido o fator que possibilitou o surgimento da nação, o fim de leis coloniais revogadas assim que D. João passou a residir no Brasil foi também para o viajante o que teria fornecido aos colonos novas esperanças e estímulos para melhoria do país, ao passo que teriam podido descobrir que seus interesses não deveriam mais ser sacrificados em favor de Portugal. ${ }^{184}$ Dentre as mudanças notadas por ele já em 1813 estava o aumento significativo do número de indivíduos que passaram a residir no Brasil. Com o aumento da população, segundo o viajante, veio também a acumulação de habilidades, do conforto e do luxo em todas suas variáveis: melhores residências, melhores maneiras no vestir, maior variedade de alimentos, etc., fazendo tudo adquirir ares de importância e excluindo o formalismo que predominava no Rio de Janeiro que, doravante, ter-se-ia tornando um lugar atraente. ${ }^{185}$

Tudo tendia a adquirir, na visão de Luccock, importância que acelerava a vida na colônia, inclusive as contestações territoriais na região sul do país, nas tentativas de estabelecer poderio português na margem setentrional do Prata ${ }^{186}$, e de autonomia, no

\footnotetext{
${ }^{184}$ John Luccock. Notes on Rio de Janeiro and the southern parts of Brasiltaken during e residence of ten years in that country from 1808 to 1818, by John Luccock.Londres : Samuel Leight, MDCCCXX, 1820. p. 562. Os trechos traduzidos em nota foram extraídos da seguinte edição: Notas sobre o Rio de Janeiro e partes meridionais do Brasil. Tomadas durante uma estada de dez anos desse país, de 1808 a 1818. Trad. de Milton da Souza Rodrigues. São Paulo: Livraria Martins, 1942.

${ }^{185}$ Ibidem, p. 547. Sobre as melhoras no ambiente luso americano, Marieta Pinheiro de Carvalho. Uma ideia ilustrada da cidade: as transformações urbanas no Rio de Janeiro de D. João VI (1808-1821). Rio de Janeiro: Odineia, 2008.; Mauricio Mario Monteiro. A construção do gosto: música e sociedade na corte do Rio de Janeiro (1808-1822). Tese (Doutorado) USP-FFLCH, São Paulo, 2011.; Maria Beatriz Nizza da Silva. Vida privada e cotidiano no Brasil. Lisboa: Estampa, 1993.

${ }^{186}$ Acrescentar novos territórios esteve entre as formas antigas de soberania atrelado ao aumento do campo de atuação e influência da coroa, acumulando súditos, riqueza e poder. A este respeito, ver: Fernando Braudel. Civilização material, economia e capitalismo. Os jogos das trocas. v.2, São Paulo: Martins Fontes, 1998.; Anderson Perry. Linhagens dos Estados Absolutistas. 3 ed. São Paulo: Brasiliense, 1995. p.31.; C. Boxer. O império colonial português..., cit. Sergio Buarque de Holanda. A colônia de Sacramento e a expansão no extremo sul. In: História da civilização Brasileira. Do descobrimento à expansão territorial. 5 ed. Rio de Janeiro/ São Paulo: Difel, 1976.
} 
norte, com o movimento político em Pernambuco em $1817^{187}$. Com relação às primeiras, tratava-se de disputas na Colônia do Sacramento que, desde a primeira metade do século XVIII, se tornavam cada vez mais problemáticas para os portugueses, na medida em que se tornavam frustrados os projetos de se estabelecer povoações em Montevidéu e Maldonado, impedindo qualquer tipo de controle na embocadura do Rio da Prata, região em competição com os castelhanos. ${ }^{188}$

A este respeito, em zonas fronteiriças, particularmente nas imprecisas devido a constantes disputas territoriais, os limites estabelecidos nos debates políticos em torno do tema pouco tinham força efetiva nos indivíduos que desenvolviam atividades produtivas, como os lavradores, pecuaristas e comerciantes da região. ${ }^{189}$ Este aspecto da região sul da América ibérica pode também ter oferecido referenciais aos viajantes na construção de representações discursivas e identitárias que se desenvolviam mediante práticas políticas e econômicas. ${ }^{190}$

Com relação ao movimento político de 1817, Luccock chamou de "extraordinária insurreição" que provavelmente teria sido impulsionada pela negligência do Governo a respeito de questões econômicas. Segundo ele, por muitos anos a população daquela província vira crescer exorbitantemente sua riqueza e, a partir do momento em que a Corte emigrou para o Rio de Janeiro, tendo como consequência o fim da ligação direta com Lisboa, os habitantes cansaram-se do jugo imposto a eles e o mesmo sentimento penetrou nas províncias vizinhas, colocando a integridade da região norte do país em iminente perigo de desagregação do restante do reino. ${ }^{191} \mathrm{O}$ episódio em Pernambuco teria oferecido oportunidade ao governo, segundo o viajante, de demonstrar extraordinária firmeza, produzindo, segundo o autor, confiança na população, alerta e dedicação ao Brasil. A este respeito escreve:

\footnotetext{
${ }^{187}$ Sobre o levante em Pernambuco ver: Denis A. Mendes Bernardes. O patriotismo constitucional. Pernambuco. São Paulo: Hucitec/Fapesp, 2006.; Evado Cabral de Melo. A outra independência. O federalismo pernambucano de 1817 a 1824. São Paulo: Editora 34, 2004.

${ }^{188}$ Maximiliano M. Menz. Entre impérios: formação do Rio Grande do Sul na crise do sistema colonial português. São Paulo: Alameda, 2009. p. 38-39. Ver também S. B. Shwartz. A América Latina na época colonial. Trad Maria B. Medina. Rio de Janeiro: Civilização Brasileira, 2002.

${ }^{189}$ Helen Osório. O império português no sul da América: estancieiros, lavradores e comerciante. Porto Alegre: UFRGS, 2007.

${ }^{190}$ A importância da cartografia para a construção geográfica da nação para o caso do Brasil pode ser vista em Jaime Cortesão. História do Brasil nos velhos mapas. Rio de Janeiro: Ministério das relações exteriores, Instituto Rio Branco, 1965.; Demérito. Magnole . O corpo da pátria: imaginação geográfica e política externa no Brasil (1808-1912). São Paulo, Ed. UNESP/Moderna, 1997.

${ }^{191}$ J. Luccock. Notes on Rio de Janeiro..., cit. p.554.
} 
I confess that. Though a foreigner and interested only in general with domestic polities, this burst of national sentiment thrilled to my very soul. I saw a hole people at once forget the execrable mode in which the administration of the country had been conducted, and the oppression under which almost every man had labored. I saw them bury it all beneath the love of a Sovereign whom they knew to be benevolent, though inactive; deceived, but not personally cruel. ${ }^{192}$

De certo modo, o momento de crise e a presença da monarquia no Brasil compunham a receita ideal para que um sentimento nacional aflorasse nos habitantes do Brasil, na visão de Luccock. A residência de D. João teria impulsionado a constituição da "nacionalidade brasileira", mas o que de fato teria garantido efetivamente a construção desta "qualidade nacional" foi a elevação do Brasil a Reino em 1815: o "national character and feeling", do qual, segundo o viajante, era o país quase totalmente destituído, proveio das medidas que colocaram o importante domínio português no mesmo patamar de privilégios e honras, semelhantes ao que gozava a "mother country". Ainda que para os autores do projeto que elevou o Brasil à condição de Reino tal acontecimento político não passasse de uma mudança de nome, Lucocck entendia que a população sentiu estar vivendo uma nova existência política, infundindo na alma um sentimento de independência, além da consciência de sua própria importância e dignidade, e a mudança de estatuto político era uma prova de que estava fixado no destino do Brasil, no futuro, "be considered as one of the nations of the world, and be no longer sacrificed to the interests of any other state."193

Depois que Portugal se viu livre do jugo francês e que fora restabelecido o quadro político da Europa após o Congresso de Viena, a ideia de regresso da Corte portuguesa para Lisboa incitou muito as aspiração políticas dos que viam no retorno da monarquia para a Europa a retomada dos interesses portugueses, colocados à margem da situação política que o Brasil adquiriu como centro econômico e de governo, a partir de $1808 .{ }^{194}$

\footnotetext{
192 Ibidem, p. 557. "Confesso que, embora estrangeiro e somente muito em geral interessado na política interna, essa explosão de sentimento nacional fez-me vibrar até o coração; vi um povo todo que, num instante, se esquecia da maneira odiosa pela qual a administração do país era ali conduzida, e da opressão debaixo da qual penava quase que todo o homem. Vios que enterravam a tudo isso sob o amor por um Soberano que eles sabiam ser bom, embora inativo; logrado, mas não pessoalmente cruel."

193 Ibidem, p. 568. "caráter e sentimento nacional", "mãe-pátria". "seria considerado como uma das nações do mundo, deixando de ser sacrificado aos interesses de outra nação."

${ }^{194}$ Sobre as alterações dos centros e das periferias do império ver A. J. R. Russel-Wood. Centros e Periferias no mundo luso-brasileiro, 1500-1800. Revista Brasileira de História, vol. 18, n. 38, 1998, p. 187-250.
} 
Tomadas as decisões de permanência no Brasil, a carta lei de 16 de Dezembro de 1815 concretizou as medidas de equiparar o Brasil à condição de Reino, junto a Portugal e Algarves. Acontecimento este que veio a se solidificar ainda mais com o falecimento de D. Maria I, em 1816, levando à coroação de D. João dois anos mais tarde, em celebração realizada às vistas dos habitantes do Brasil, fato que proporcionou às populações do agora Reino, uma oportunidade de apreciação do seu soberano, fixado em terras americanas. Portugal, Brasil e Algarves estabeleceram, então, situação legítima de igualdade, e a unidade do Estado, encarada sob o ponto de vista da soberania, tinha na figura do rei e do poder régio a sua expressão. ${ }^{195} \mathrm{O}$ caráter circunstancial que caracterizou o primeiro momento de ausência da realeza de sua sede europeia perdera definitivamente o sentido a partir de 1815, quando um vago sentimento de orfandade passou a se propagar entre as elites dirigentes de Portugal, acirrando as divergências entre reinóis e americanos, na última tentativa de sustentação da política territorial da Monarquia portuguesa. ${ }^{196}$

Para bem compreender a extensão e importância do "feeling of nationality" que o viajante pretendia enxergar nesse acontecimento político do Brasil, Luccock faz uso da rivalidade entre as províncias, que compunham partes desconectadas de um império, e que entre outros aspectos, talvez não possuíssem outro laço comum a não ser o da língua. Segundo ele, quando a Corte chegou ao Rio, se constatou que as Colônias consistiam em partes tão desarticuladas que, diante de qualquer ameaça, poderiam se desarranjar, o que tornaria muito precária a situação dos reais imigrantes. A habilidade do governo aliada à ajuda Grã-Bretanha, comentava, foi o que manteve o Brasil todo dentro dos mesmos laços,

to turn the people's attention from Lisbon to Rio, to make them feel that the latter city had become the center of their union, the Capital of their widely diffused people, the source of their security, the focus and fountain of their wealth and their honor. ${ }^{197}$

\footnotetext{
195 Zília Osório de Castro. A independência do Brasil na imprensa periódica portuguesa (1822-1823). Revista de História das Ideias, vol 15., 1993, p. 664.

196 Algumas entre muitas contribuições sobre a política territorial da monarquia portuguesa podem ser vistas em: Ana Cristina Araújo. Um império, um reino e uma monarquia na América: as vésperas da independência do Brasil. In: I. Jancsó. Independências: historia e historiografia. São Paulo: Hucitec/Fapesp, 2005.; Ana Cristina Nogueira da silva. O Modelo Espacial do Estado Moderno. Lisboa: Estampa, 1998.

${ }^{197}$ J. Lucocck. Notes on Rio de Janeiro..., cit. p 568-569. "sentimento nacional”, "para desviar a atenção do povo, de Lisboa para o Rio, para levá-lo a sentir nesta última cidade o centro de sua unidade, a Capital
} 
Nota-se que o viajante se esforçou em unir a população num mesmo vínculo de pertencimento, ainda que reconhecendo a diversidade da população luso americana num espaço que, segundo ele próprio, não abarcava somente pessoas denominadas "brasileiras". Para Luccock, o primeiro esforço na realização da unidade territorial teria sido dado com a abertura dos portos ao comércio estrangeiro, medida muito favorável aos britânicos, e que também teria acarretado "transformação milagrosa" nas maneiras da população. Mas isto não teria levado, segundo ele, a um sentimento especial por determinado país; teria contribuído, ao contrário, para fazer com que cada província, sem consideração pelo interesse geral, se colocasse do lado em que fossem maiores suas vantagens comerciais. Mas assim que declarado Reino, o Brasil teria revelado, segundo o viajante, uma "unanimidade de sentimento" que teria reunido num ato comum a homogeneidade do trono:

Address of exultation and gratitude to the Sovereign poured in, by one simultaneous movement, from every part of country, and the most remote and obscure township felt proud of the privilege which admitted it to address its own sovereign under a Brazilian title, on Brazilian ground. ${ }^{198}$

E esse "feeling of nationality" continuou sendo fortalecido por ocasiões de natureza diversa, segundo ele, tais como as ocasiões festivas, celebrações, aclamações, que consequentemente implicariam mudanças nos gostos, nos níveis de instrução, etc., e para os que já observavam a influência que os acontecimentos exerceriam sobre o "national character and union", a aclamação do "first King of Brazil", referindo-se à coroação de D. João. ${ }^{199}$

O compartilhamento da figura do soberano em festas que compunham o cotidiano real foi aspecto de natureza significativa para muitos viajantes, e guarda relação com a própria questão das disparidades entre as províncias, na medida em que os atos solenes da Monarquia, celebradas na América, reuniam em torno do soberano os seus súditos. A própria noção de vassalagem, conceito essencial na manutenção da ordem

de sua população tão grandemente difusa, a fonte de sua segurança, o foco e a nascente de sua riqueza e de sua honra".

${ }^{198}$ Ibidem, p. 569. "Surgiram discursos de regozijo e gratidão para com o Soberano, como que por um impulso simultâneo, de todos os pontos do país, e os mais remotos e obscuros povoados mostraram-se orgulhosos dos privilégios que os facultava dirigirem-se a seu próprio Soberano por um título brasileiro e sobre terras brasileiras.", "sentimento de nacionalidade", "caráter e a união nacional”, "primeiro Rei do Brasil"

${ }^{199}$ Ibidem, p. 570”, “sentimento de nacionalidade", "caráter e a união nacional”, "primeiro Rei do Brasil”. 
monárquica $^{200}$, manifestava-se de frágil adesão na América portuguesa, tornando necessária a ordenação de alianças que estimulassem nos habitantes a ideia de unidade. Vivenciou-se na América portuguesa a partir das cerimônias uma temporalidade da realeza de especificidade própria, na qual se destacavam a figura do soberano, seus atributos e signos e, principalmente, a capacidade de instaurar uma liturgia do poder associada às estratégias políticas. ${ }^{201}$

Além disto, Luccock observava que a circulação amplamente difundida do “Correio Braziliense", periódico publicados por Hipólito da Costa em Londres entre os anos de 1808 a 1822, e o "Patriota", publicado no Rio de Janeiro, em 1813 e 1814, e que tinha por editor Manoel Ferreira de Araújo Guimarães, responsável na época pela Gazeta do Rio de Janeiro ${ }^{202}$, difundiam na população um conhecimento melhor dele próprio e do mundo - conhecimento este que incluía informações de descrições dos viajantes, frequentemente anunciados nos periódicos. A construção de boas estradas e melhores comunicações era considerada pelo viajante coisa de máxima importância para

\footnotetext{
${ }^{200}$ Marcos Aurélio de Paula Pereira. Vassalos, Fidalgos e Cidadãos: identidade e Cultura Política do Reino à América Portuguesa.. XXVII Simpósio Nacional de História. Conhecimento histórico e dialogal. Natal-RN, jul. 2013. O autor analisa neste trabalho o conceito de vassalagem na cultura política do Antigo Regime.; outras referências sobre os múltiplos processos de estruturação da sociedade nos moldes políticos do império português, Maria Fernanda Bicalho. Elites coloniais: a nobreza da terra e o governo de conquistas. In: Nino G. C. Monteiro e Mafalda S. da Cunha (orgs.) Optmas pars: elites iberoamericanas no Antigo Regime. Lisboa: Impensa de Ciências Sociais, 2005.; Antonio Manuel Hespanha e Ângela Barreto Xavier. As redes clientelares. in: José Mattoso (dir.) História de Portugal. o Antigo Regime (1620-1807). Lisboa: Circulo de Leitores, 1992.

${ }^{201}$ I. L. Souza. Pátria coroada..., cit. p. 209-2014. A autora observa que as festas movimentavam um campo imagético investido de usos políticos, carregados de permanências que concedem ao historiador permissão metodológica para tentar reconstruir tal panorama, não se tratando de encontrar ou forjar um modelo, mas de reconstituir um tempo ritualizado desse universo social.

${ }^{202}$ A história da imprensa no Brasil é assunto bastante peculiar (principalmente se comparada à imprensa na América hispânica). Teve início em 1808, com a vinda da Família Real ao Rio de Janeiro, sendo expressamente proibida anteriormente. Alguns autores que trabalharam com a temática são: Nelson Werneck Sodré. História da imprensa no Brasil. 3 ed. São Paulo: Martins Fontes, 1983.; Marcília Rosa Periotto. O Correiro Brasiliense (1808-1822). O ensino mútuo e o desenvolvimento material do Brasil. Revista Histedbr (On-line), Campinas, n.45, p. 49-61, mar 2012.; ___. O papel da imprensa no processo de construção da nação: a "vocação pedagógica" do Correio Braziliense. Revista Histedbr. Online. UNICAMP. Campinas, n. 16, p. 61-83, dez. 2004. Isabel Lustosa. O Correio Brasiliense (18081822): a imprensa brasileira nasceu inglesa e liberal. In: Eliana de Freitas Dutra \& Jean-Yves Mollier (orgs.) Política, nação e edição: o lugar dos impressos na construção da vida no Brasil, Europa e Américas nos séculos XVIII e XIX. São Paulo: Annablume, 2006.; I. Janscó \& A. Slemian. Um caso de patriotismo imperial. Hipólito da Costa e o Correio Braziliense. São Paulo/Brasilia: Imprensa Oficial do Estado-Correio Brasiliense, 2002 (vol. XXX, Estudos).; Lorelai Kury. A Ciência útil em O Patriota (Rio de Janeiro, 1813-1814) Revista Brasileira de História da Ciência, Rio de Janeiro, v. 4, n. 2, p. 115-124, jul | dez 2011; ___. (org.) Iluminismo e império no Brasil- O Patriota (1813-1814). Rio de Janeiro: Editora Fiocruz, 2007.; José Carlos Oliveira. "A cultura científica e a Gazeta do Rio de Janeiro (1808-1821)", Revista da Sociedade Brasileira de História da Ciência, Campinas, n.17, p. 2958, jan./jun.1997.; Marco Morel. Independência no papel: a imprensa periódica. In: I. Janscó. Independência..., cit. p. 617-635.; Lúcia Maria Bastos Pereira das Neves. Os panfletos políticos e cultura política da independência do Brasil. In: I. Jancsó. Independências..., cit., p. 637-675.
} 
um Estado na infância, aspectos promovidos com toda influência pelo Conde de Linhares, principalmente as melhorias na ligação dos portos do mar com o interior. ${ }^{203}$ Quando a última guerra napoleônica terminou ${ }^{204}$, comentava Luccock, a influência que a Grã-Bretanha tinha sobre o "Brazilian Continent" ter-se-ia tornado menos decidida, como era de se esperar, esbarrando na concorrência de outras nações; mas o Rei permaneceu amigo dos britânicos, demonstrando-se grato ao tratamento que recebera da Nação britânica. ${ }^{205}$

Com os princípios de liberdade já arraigados, a grande falha na consolidação do poderio do Brasil entre os impérios novos, segundo o viajante, estaria "numa povoação eficiente", devendo o governo restabelecer a Constituição portuguesa e, assim, mostrar ao mundo que a rígida administração da justiça e o livre exercício da religião seriam mantidos, fazendo convergir para o país a corrente da imigração. ${ }^{206}$ Ainda que o viajante anunciasse expressões que aplicavam ao Brasil uma posição diferenciada no quadro imperial, tais como "Monarch of the South", "Crown of Brazil", "Brazilian Continent", notamos que a suposta construção de uma "nação brasileira" não estava apartada, em Luccock, dos laços estabelecidos com Portugal, ao se referir à constituição deste país. Importa ter em mente que o Brasil, enquanto entidade política emergente nas primeiras décadas do século XIX, não era depositário de adesão emocional, tal como uma historiografia essencialmente anacrônica postula, estando o conceito de nação neste período carregado de uma enorme fluidez típica de linguagens políticas presentes em todo o universo atlântico. ${ }^{207}$ Podemos inferir que o tema das identidades naquele

\footnotetext{
203 J. Luccock. Notes on Rio de Janeiro..., cit. 574.

${ }^{204}$ Fugido do exílio, Napoleão Bonaparte retomou o controle do governo francês em 1815, período que ficou conhecido como Governo de Cem dias. Seu poder foi definitivamente destruído na Batalha de Waterloo, sob liderança inglesa, sendo exilado para a ilha de Santa Helena, agora até a sua morte, em 1821. Ver Beatriz Westin de Cerqueira Leite. A vida como expressão da glória: Napoleão Bonaparte. São Paulo: Altamira, 2011.

${ }^{205}$ J. Luccock. Notes on Rio de Janeiro..., cit, p. 600. "Continente Brasileiro"

${ }^{206}$ Ibidem, p.602.

${ }^{207}$ I. Jancsó \&J. P. G. Pimenta. Peças de um mosaico ..., cit., p. 440. A contribuição particular do esclarecimento das mutações do termo "nação" está na eliminação do equivoco imposto pelo fundamento étnico das nações contemporâneas e às interpretações dos sentimentos de identidade, segundo J. C. Chiaramonte. Três modalidades de nação são resumidas pelo autor: "1) o termo nação foi usado durante séculos com um sentido puramente étnico; 2) surge, em seguida, outro sentido - sem que o anterior desapareça -, estritamente político, aparentemente durante o século XVII e que se generaliza durante o XVIII, bem antes da Revolução Francesa, sentido que exclui qualquer referência étnica; 3) numa terceira fase, paralelamente ao Romantismo, ocorre a conjunção de ambos os usos, o mais antigo, étnico, e o mais recente, político, ao chamado princípio das nacionalidades. Foi recentemente, portanto, que a etnicidade converteu-se em fundamento da legitimidade política, caráter que estava ausente nas diversas manifestações de identidade registradas pelos historiadores dos séculos XVI a XVIII - e que costumam equivocadamente ser rotuladas como 'pré-nacionalismos', 'protonacionalismos' ou por meio de conceitos semelhantes." José Carlos Chiaramonte. Metamorfoses no conceito de nação. In I. Jancsó (org.) Brasil:
} 
contexto destaca menos a identificação de uma "nacionalidade brasileira" associada com o todo corpo do país, do que a construção de um Estado centralizado capaz de manter sob controle as divergências internas. E o "ser brasileiro" esteve, assim, inserido em mudanças políticas e econômicas que refletiam na dinâmica do império lusitano.

Alguns dos efeitos mais visíveis da chegada da Corte ao Rio de Janeiro também foram posteriormente registrados por Graham, que esteve no país durante parte dos anos 1821, 1822 e 1823, iniciando seu diário da primeira estada no Brasil em 22 de setembro de 1821. A viajante notava o aumento das relações comerciais no país produzido pelo dinheiro trazido pelos imigrantes de Portugal, que beneficiou o emprego de capital e especulações comerciais. A disseminação de notícias com a fundação de uma gazeta $\operatorname{regular}^{208}$,foi o primeiro passo, segundo Grahan, no despertar da curiosidade intelectual, tão necessária num país em que o progresso estaria acontecendo de forma rápida e diária.

Com a elevação do Brasil à dignidade de Reino, as fórmulas e títulos ficaram em pé de igualdade com Portugal, medida, segundo ela, justa e de orgulho para os habitantes do Brasil. Para Graham, as províncias se uniram por ocasião dos agradecimentos - tópico recorrente por parte dos viajantes - e afastando a população naquele momento de qualquer outra consideração. ${ }^{209}$ Estabelecidas as bases políticas do Reino, o ano de 1818 teria dado lugar a acontecimentos que, segundo a viajante, garantiriam a fundação do império no Brasil: a coroação de D. João VI e o nascimento da princesa D. Maria da Glória. Estes fatos teriam sido um grato acontecimento para a população do Brasil, que teve na herdeira nascida entre eles a garantia de que a sede do governo não seria mais transferida. ${ }^{210}$ No entanto, muitas das melhorias começadas com a vinda da Corte, e que se esperava que seriam de grande valia para o país, cessaram, segundo ela, com a reemigração da corte portuguesa, produzindo males de grandes proporções para o Brasil:

formação do Estado e da Nação. São Paulo: Hucitec, 2003. p. 85.; Marco A. Pamplona. Nación. Brasil. ”. In: Javier Fernández Sebastián (dir.). Diccionario político y social del mundo iberoamericano .La era de las revoluciones, 1750-1850. Fundación Carolina/Centro de Estudios Políticos y Constitucionales. Madri, 2009.

${ }^{208}$ Maria Graham. Journal to a voyage to Brazil and residence there during parts of the years 1821, 1822 and 1823.London: Longman, Hurst, Rees, Orme, Brown, and Grenn, 1824. p.50. A viajante se referiu à Gazeta do Rio de Janeiro, fundada em 10 de setembro de 1808, no Rio de Janeiro, como jornal oficial da Corte. Os trechos traduzidos em nota foram extraídos da seguinte edição: Diário de uma viagem ao Brasil e de uma estada nesse país durante parte dos anos 1821, 1822 e 1823. Trad. de Américo Jacobina Lacombe. São Paulo: Cia. Editora Nacional, 1956.

${ }^{209}$ M. Graham. Journal to a voyage ...., cit. p. 56.

${ }^{210}$ Ibidem, p. 40. 
It is computed that fifty millions of crusadoes, at least, were carried out of the country by the Portuguese return to Lisbon [...] the treasury was left so poor, that he was obliged to delay or modify the increase of military pay promised on the King's departure, a circumstance that occasioned much disquiet in several provinces [...] and the wonder is, not that disturbance in various quarters took place after the departure of the King, but that they were not of a more fierce and fatal tendency. ${ }^{211}$

Testemunha do movimento político de independência, Graham analisou o Brasil em muitos aspectos que, entre outros assuntos, colocava a questão da nação através do enquadramento político do Estado: deveria o Brasil permanecer parte da monarquia portuguesa, com jurisdição civil e criminal separada e suprema, sob governo do príncipe; ou deveria voltar à situação desprezível em que estivera desde a descoberta? ${ }^{212}$ Se as condições para a existência de uma "nação brasileira" não estavam colocadas, as possibilidades do Brasil voltar a ser de novo reduzido à condição de colônia com o retorno do Príncipe em obediência às Cortes era uma degradação que, segundo Graham, não garantindo direitos e privilégios iguais aos da "mãe-pátria", os "brasileiros" não estavam dispostos a se submeter.

A retórica da recolonização tem interpretações consagradas na historiografia, que abordou qual a importância e as influências que a reemigração da Corte portuguesa para a Europa teria exercido no processo de independência do Brasil. ${ }^{213} \mathrm{O}$ termo foi interpretado por um historiador como "neologismo", cunhado durante o processo de independência que denunciaria as disposições legais impostas ao Brasil pelas Cortes de Lisboa. ${ }^{214}$ Outro, analisou a revolução da década de vinte em Portugal como uma rebelião liberal contraditória em si mesma, "liberal, antiabsolutista e

\footnotetext{
${ }^{211}$ Ibidem, p. 70-71. “Calcula-se em cinquenta milhões de cruzados, no mínimo, a soma levada do país pelos portugueses de volta a Lisboa [...] O tesouro ficou tão pobre que ele foi obrigado a adiar ou modificar o aumento dos pagamentos militares prometido na partida do rei, situação que provocou muita inquietação em várias províncias [...] Não é de admirar-se que tenha havido distúrbios em vários setores após a partida do rei, mas que não tenham sido de natureza mais feroz e fatal".

${ }^{212}$ Ibidem, p. 71-72.

${ }^{213}$ Alguns trabalhos que tratam do tema: Valentim Alexandre. Os sentidos do Império..., cit.; Maria de Lourdes Viana Lyra. A utopia do poderoso império..., cit. C. H. S. Oliveira. A astúcia Liberal. Relações de mercado e projetos políticos no Rio de Janeiro (1820-1824). Bragança paulista: Edufsc-icone, 1999.

${ }^{214}$ Trata-se de Antônio Penalves Rocha. A recolonização do Brasil pelas Cortes. História de uma invenção historiográfica. São Paulo: UNESP, 2009.
} 
contrarrevolucionária pela feição colonialista em relação ao Brasil." ${ }^{215}$ Tendo sido as referências às ações recolonizadoras incorporadas por escritores brasileiros e portugueses ainda no século XIX, dando como certo que a Independência do Brasil teria sido resultado de uma reação a tais medidas, a historiografia do século $\mathrm{XX}$ seguiu a mesma explicação, dando, desta vez, ênfase às questões econômicas. ${ }^{216}$ Frente a estas discussões, surge um novo debate historiográfico que analisa os planos dos deputados portugueses de erigir um governo centralizado não como medidas recolozinadoras, mas integracionistas, ampliando o controle do Estado e assegurando a unidade imperial. ${ }^{217}$

A questão também não passou despercebida aos observadores contemporâneos da política do Brasil nas primeiras décadas dos oitocentos e suas contradições com Portugal, sendo este assunto alvo das análises de viajantes que almejavam nos seus escritos a representação de um Brasil em processo de construção de sua nacionalidade, na qual o "brasileiro" ia sendo construído. ${ }^{218}$

A 9 de janeiro de 1822 Graham escrevia ser um dia decisivo no destino do Brasil, pois D. Pedro, desejoso em obedecer as ordens que lhe tinham sido dadas - partir imediatamente para a Europa e empreender uma viagem pela Espanha, França e Inglaterra - ao mesmo tempo não podia deixar de sofrer como pessoa diante da possibilidade de seu retorno a Portugal. A relação entre governante e América, primeiro aliada a D. João, depois intensificada com D. Pedro I, assentava uma disposição que desvalorizava a filiação do Príncipe com a linhagem portuguesa, chegando mesmo a se forjar uma espécie de "marco-zero" na ordem política do Brasil nas vias da Independência. ${ }^{219}$ Os habitantes do Brasil esperavam ardentemente a permanência do príncipe no país, segundo Graham, e havia os que previam a "possibilidade de se

\footnotetext{
${ }^{215}$ José Honório Rodrigues. Independência: revolução e contra-revolução - a política internacional. São Paulo: Perspectiva, 1972. p. 234.235. Segundo o autor, a controvérsia foi ressuscitada por trabalhos que divergiam da corrente principal, considerando como marginal para o processo de independência as relações entre Portugal e Brasil.

${ }^{216}$ A. P. Rocha. A recolonização do Brasil..., cit. p. 9.

${ }^{217}$ Segundo Marcia R. Berbel, os deputados representantes das províncias do Brasil nas Cortes não aceitavam as restrições que decorriam dos projetos de centralização do Estado, encabeçados pelos deputados portugueses, e, por isso, estes foram acusados de recolonizadores. M. R. Berbel. A retórica da recolonização. In: I. Janscó. Indepêndencias...., cit.

${ }^{218}$ Gladys Ribeiro escreve que "brasileiro" era aquele que "lutava pela liberdade, pela Monarquia Representativa e Constitucional, aqueles que iam contra as medidas recolonizadoras das Cortes, não importava se o seu local de nascimento fosse o Brasil ou Portugal." Gladys Sabina Ribeiro. A liberdade em construção: identidade nacional e conflitos antilusitanos no primeiro reinado. Rio de Janeiro: Relume Dumará. FAPERJ, 2006. p. 46-48. Ver também I. L. Souza. As várias representações do Brasil. Pátria Coroada... cit, p. 113.

${ }^{219}$ I. L. Souza. Pátria coroada..., cit. p. 222-223.
} 
declarar ele abertamente desta terra" ${ }^{220}$ Qualquer que fosse a disposição final, o fato de Graham presenciar os acontecimentos políticos que se desenrolavam naquele momento conferiu a seu diário de viagem uma versão desembaraçada dos episódios.

O contexto em que viajavam é parte importante nas observações que os viajantes fizeram do Brasil e dos fatos históricos que presenciaram. Tollenare, por exemplo, fazia análise sobre Pernambuco na época em que chegou ao Brasil, em 1816, associando as transformações do país à chegada da Corte, do ponto de vista econômico, que era o que lhe interessava na viagem, a princípio. O viajante comentava que antes dos acontecimentos que se desenrolaram em 1807, aos quais ele titulou de revolução e que teriam exercido grande influência na prosperidade do país, os plantadores estavam endividados e com os engenhos em decadência. No entanto, apesar das circunstâncias, estaria reservado ao Brasil destino brilhante, as suas comunicações com o mundo inteiro despertaria a indústria e sua liberdade estaria garantida, já que não faria mais parte do jogo dos monopólios. ${ }^{221}$ Análise com frequência expressada pelos viajantes, Tollenare não foge de tal opinião. No entanto, a Revolução de 1817 em Pernambuco talvez tenha sido o acontecimento que mais lhe tirou o foco das observações comerciais que lhe tinham feito viajar até o Brasil. Testemunhou de perto o desenrolar do movimento e não passou ileso de considerações sobre o tema. Região de forte expressão política, Pernambuco viveu sob o espectro da busca por autonomias, pela defesa do livre comércio e pelo fim dos sistemas de monopólios, tendo no federalismo a brecha de ideias separatista ao longo os anos de 1817 a $1824 .^{222}$

Sobre este assunto, Tollenare escrevia em março de 1817 que o estandarte da independência havia sido levantado em Pernambuco. Notava que se estavam os "portugais" tranquilos ao lado dos negros, não podiam gozar da mesma situação ao lado dos “ creoulos brésiliens”. Estes eram mais indolentes e invejavam a prosperidade comercial daqueles, ao invés de tentar os imitar na atividade. Seguia comentando:

On parlait de conciliabules tenus sous les formes maçonniques. Il y avait eu des repas brésiliens d'óu l'on avait exclu le pain et le vin d'Europe. On avait servi

\footnotetext{
${ }^{220}$ Maria Graham. Journal to a voyage..., cit. p. 217.

${ }^{221}$ L. F. de Tollenare. Notes dominicalesprises pendant um Voyage em Portugal etauBrésil. Ed. et com commentaires Léon Bourdon. Paris, PressesUniversitaires de France, 1971-1973, 3 vv.. p. 361. Os trechos em português foram consultados na edição Notas dominicais tomadas durante uma viagem em Portugal e ao Brasil em 1816, 1817 e 1818. Progresso: São Paulo/ Salvador, 1956.

${ }^{222}$ E. C. Melo. A outra independência..., cit. p.18.; Ver também Denis A. M. Bernardes. Um Império entre Repúblicas: Brasil, século XIX. São Paulo: Global, 1983.
} 
avec ostentation le manioc et le mauvais tafia du pays. Enfin on y avait porté des toast pour l'indépendence, contra la tyrannie royale et contre les Portugais d'Europe. $^{223}$

Ainda assim, Tollenare notava que como se falava muito pouco de política em Pernambuco e era raro que ouvisse falar em reuniões dos "bresiliens", já que a maioria se ocupava de seus negócios particulares e os jornais pouco circulavam, ficando as pessoas algumas semanas sem notícias. De qualquer forma, suas observações, feitas de perto, o levou a identificar na revolta a situação das colônias espanholas, supostamente exposta a todas as exaltações das dissenções civis, numa terra isenta de guerras a cento e cinquenta anos, segundo ele, que teve sua prosperidade depois da emancipação do Brasil e da chegada da Corte ${ }^{224}$. Perguntava-se, segundo ele, sobre a sorte da nação, confiada a indivíduos de opiniões opostas e todas perigosas, como a promessa de uma administração "mois coûteuse et plus nationale." 225

Segundo Tollernare, no movimento de 1817 só se solenizava sinceramente os Americanos do Norte, pois se desconfiava dos ingleses por causa de sua aliança com Portugal, e dos franceses pela legitimidade antiga que restabeleceram após o fim das restrições que Napoleão impôs ao país. E os prognósticos não eram animadores, do seu ponto de vista, que via, apesar dos protestos de amizade dos novos governantes aos estrangeiros, os sinais de calamidades que o país iria experimentar antes que alcançasse a felicidade política que procurava. ${ }^{226}$

Tollenare assinalava uma diferença básica entre o caráter político da nação francesa e da suposta "nação brasileira": no Brasil ainda havia pouco do "espírito nacional" entre as províncias, que subordinaria tudo ao interesse comum, enquanto que a França, neste particular, teria apenas um sistema nervoso, o que resultava para o Brasil em pouca comunicação entre as partes. ${ }^{227}$ Aspecto bastante recorrente nos viajantes analisados, as discrepâncias entre as partes que compunham o império têm forte relação

\footnotetext{
223 L. F. de Tollenare. Notes Dominicales..., cit. p. 544. "portugueses"; crioulos brasileiros" (nesta expressão, o autor faz referência aos homens brancos, "portugueses" nascidos no Brasil); "Falava-se em conciliábulos feitos sob as formas maçônicas; [nos] banquetes se excluía o pão e o vinho da Europa; servia-se com ostentação a farinha de mandioca e a ruim aguardente nacionais; enfim, tinham sido erguidos brindes à independência contra a tirania real e contra os portugueses da Europa."

${ }^{224}$ Ibidem, p.567.

${ }^{225}$ Ibidem, p. 568. "menos custosa e mais nacional".

${ }^{226}$ Ibidem, p.569.

${ }^{227}$ Ibidem, p. 762.
} 
com a autonomia que alguns grupos sociais conquistaram durante o período colonial. ${ }^{228}$ A continuada expansão territorial da nação portuguesa, e a experiência política acumulada pelos grupos que se estabeleceram nas diversas partes do império, reverberaram de diversas formas em cada região do Brasil. Isto provocava mudanças na relação entre a política local e central, que a cada ocasião reequilibrava a dinâmica entre as partes e as noções de pertencimento ao Império português. ${ }^{229}$

A opinião de Tollenare sobre o assunto estabelecia relação com a ideia de que no Brasil, assim que este deixou de ser considerado colônia, transferida a sede do governo para cá e elevado à condição de Reino, "portugueses" e "brasileiros" tornaram-se concidadãos, recomendando-lhes que se tratassem como irmãos. Porém, o viajante perguntava-se o porquê da administração tratar os dois como estranhos um ao outro. ${ }^{230}$ Numa apreciação geral das condições impostas a "portugueses" e "brasileiros", o viajante argumentava com a necessidade de fazer valer na prática o que os anais políticos do império já havia feito valer: igualdade de condições políticas entre Portugal e Brasil. Desta perspectiva, notamos que Tollenare enfatiza a união do Brasil como um todo e a coexistência de duas nações em uma é recorrentemente aludida no seu texto, mostrando que se uma "nação brasileira" ainda não era identificada independente da nação portuguesa, ao menos as bases para sua formação pareciam estar dadas.

Numa apreciação mais sociológica da questão, Debret que publicou sua obra em 1831, analisa o tripé da sociedade luso americana: o europeu, o indígena e o africano assunto que terá fortuna na historiografia e no pensamento geral sobre o Brasil, passando por Von Martius, Gilberto Freyre, Florestan Fernandes, entre outros ${ }^{231}-\mathrm{em}$

\footnotetext{
${ }^{228}$ Ver Rodrigo Recupero. A formação da elite colonial: Brasil 1530-1630. São Paulo: Alameda, 2009.

${ }^{229}$ Sobre os níveis de identidades regionais presentes no período colonial ver F. A. Novais. Condições da privacidade na América colonial. In: L. M. Souza (org.) História da vida privada no Brasil, v. 1. São Paulo: Cia. das Letras, 1997.; I. Jancsó \& J. P. Pimenta. Peças de um mosaico..., cit. Para uma análise da relação das formas de identidade regional e a formação nacional brasileira ver Marcia Berbel. Pátria e patriotas em Pernambuco (1817-1822): nação, identidade e vocabulário politico. In: I. Jnascó. Brasil..., cit. p. 345-363.

${ }^{230}$ L. F. de Tollenare. Notes Dominicales..., cit.. p. 717.

${ }^{231}$ Para quem quer que fosse escrever a história do Brasil, jamais poderia perder de vista os três raças que concorreram para o desenvolvimento do homem brasileiro, segundo Von Martius. Para ele, a partir do encontro, das relações mútuas e das mudanças dessas três raças, teria se formado a população, história por este motivo de cunho bastante peculiar. A historiografia da década de 1930 também postulava a miscigenação e a importância hierárquica das raças na formação da sociedade brasileira. A ideia de miscigenação como aspecto positivo das relações raciais brasileiras foram desenvolvidas por Gilberto Freyre, que colocava a desigualdade racial como produto da escravidão e da adoção de valores tradicionais de dominação. Estas diferenças, no entanto, foram classificadas por ele como fluidas, tendo enfocado a sociabilidade entre pessoas da mesma classe. Uma visão radicalmente formulada por F. Fernandes, em contraposição aos pensamentos de Freyre, apontava que a democracia racial no Brasil era um mito, associando a miscigenação à campanha de branqueamento da sociedade. Karl Friedrich Philipp von Martius. Como se deve escrever a História do Brasil. Revista do IHGB. Rio de Janeiro 6 (24): 389 -
} 
vista dos meios pelos quais a civilização teria alcançado seu estágio até início do século XIX.

$\mathrm{Na}$ costa do Brasil, o português penetrou timidamente as florestas próximas das praias, enquanto o indígena amedrontado com o homem desconhecido observava de longe entre as florestas virgens. Do encontro dos dois, teria surgido uma secreta simpatia que, segundo ele, logo se transformou na entrega do indígena à sedução do europeu. Diante da cobiça dos soberanos europeus, que destruiu anos de relação entre ambos, a população indígena se retirou enquanto o "portugais enfin établi au Brésil" desistia provisoriamente de escravizá-la. Neste momento entravam em cena os escravos africanos, que segundo Debret foram entregues aos portugueses para ajudar a desbravar uma terra que prometia minas de ouro e diamantes. Sem o consolo do passado e confiança no futuro, comentava o viajante, os africanos definhavam longe de pátria, sem nenhuma recompensa pelos seus serviços prestados. A civilização no Brasil mantinhase, dessa forma, estacionária até a chegada da Corte de Portugal em 1808, numa colônia abandonada até aquele momento aos cuidados de Vice-Reis, e viu em 1822 ser colocado sobre a cabeça de D. Pedro o título de Defensor Perpétuo do Brasil, acrescentado mais tarde ao de "empereur de as patrie adoptive, deliverée désamois de l'influence portugaise" E como parte desta evolução, se colocava ele como artista e pintor de história que, por solicitação do governo português, empreendeu viagem ao Brasil a fim de fundar Instituto de Belas Artes no Rio de Janeiro em 1816, e em dez anos divulgou na capital do Reino diversas obras que despertaram o gosto pelas artes aos "jeune Brésilien", assegurando o êxito da empresa. ${ }^{232}$

Podemos considerar que a influência francesa na constituição da sociedade, que teve as possibilidades de mudança concretizadas com a presença da Corte, segundo Debret, permitindo avanço no caminho evolutivo percorrido por outras nações em estágio adiantado de civilização, é o objetivo principal do artista viajante. O resultado

411. Janeiro de 1845. Revista Trimensal de História e Geografia ou Jornal do Instituto Histórico e Geográfico Brasileiro. N. 24, janeiro de 1845. Gilberto Freyre. Casa-grande e Senzala. Formação da família brasileira sob regime da economia patriarcal. 51 ed. São Paulo: Global Editora, 2011. F. Fernandes. A integração do negro na sociedade de classes. 2v. São Paulo: Globo, 2011.

${ }^{232}$ Jean Baptiste Debret. Voyage Pittoresque et Historique au Brésil, ou séjour d'um Artiste Français au Brésil, Depuis 1816 junsqu'em 1831 inclusivement, Époques de l'Avénement et de l' abdication de S.M.D. Pedro I, Foundateur de l'Empire Brésilien. Paris: Firmen Didot Frèses, 1834-1839, 3 vv. p.II. Os trechos traduzidos em nota foram extraídos da seguinte edição: Viagem pitoresca e histórica ao Brasil. 2 T. trad. Sérgio Milliet. EDUSP/ Itatiaia: São Paulo/ Belo Horizonte. 1978. "português enraizado no Brasil"; "Imperador de sua pátria adotiva, libertada para sempre da influência portuguesa"; "jovens brasileiros". 
dos anos que passou entre os "brasileiros", segundo Debret, teria servido para garantir o apreço pela arte, para ele essencial no processo de construção da nação.

Caindo bem à designação feita por ele próprio de se tratar de um "pintor de história", os passos que trouxeram à civilização "de ce peuple nouve-element régéneré" não poderiam ser esquecidos, fazendo dos episódios colhidos in loco, segundo ele, uma contribuição para o restabelecimento dos traços já quase apagados do caminho que foi percorrido pelo Brasil nos três séculos de colonização, que culminariam nos avanços políticos, econômicos e principalmente, na sua visão, no progresso moral e intelectual dos luso americanos. ${ }^{233}$ No terceiro volume da obra, que foi organizada, de acordo com o viajante, numa lógica evolutiva dos caminhos percorridos pelos habitantes do Brasil, a denominação "civilizado" é empregada para se referir a estes com desenvoltura. Sobre este escrevia que era preciso acrescentar, para ser justo, que o "bresilien"

orgueilleux de son premier etan, sut depuis em sontenir les heureuses conséquences, par une énergie sagement dirigée, gage irrécurable d'um glorieux avenir [...] car, dans cette belle contrée, plus que partout ailleurs, les rapidez progrès de la civilisation dénaturent chaque jour le caractere primitif er les habitudes nationales du Brésilien. ${ }^{234}$

Os acontecimentos históricos que se desenrolaram no Brasil em 15 anos, comentava, podiam ser comparados ao resultado de vários séculos em outros países e teria sido, entretanto, por um contraste que um rei português veio acordar o "brasileiro", supostamente em apatia por três séculos. ${ }^{235}$ Foi assim que segundo Debret, ter-se-iam iniciado as revoluções nas quais poderiam figurar personagens "portugueses" e "brasileiros" na substituição do poder estrangeiro pelo "pouveir national",236, na

\footnotetext{
${ }^{233}$ J. B. Debret. Voyage Pittoresque et Historique..., cit. p. I. "esse povo recém-regenerado".

${ }^{234}$ Ibidem, p. I. "vaidoso do seu próprio impulso, soube sustentar desde então as felizes consequências dele, com uma energia sabiamente orientada , penhor indiscutível de um glorioso futuro. [...]pois neste belo país, como em toda parte aliás, os rápidos progressos da civilização modificam dia a dia o caráter primitivo e os hábitos nacionais do Brasileiro".

${ }^{235}$ Cristiane Alves Camacho dos Santos analisa no capítulo de sua dissertação "A vitória dos 'três séculos de opressão' e a valorização das experiências" como o discurso histórico e a leitura da colonização portuguesa na América no processo de independência deu materialidade à singularização da História do Brasil. Segundo a autora, independente da forma como a colonização portuguesa era compreendida, como um passado de prosperidade e civilização, ou como um passado de opressão e avareza comercial, o processo de colonização era entendido como momento encerrado, que não oferecia mais lições para o presente. C. A. C. Santos. Escrevendo a história do Futuro. A leitura do passado no processo de independência do Brasil. Dissertação (Mestrado). FFLCH-USP, São Paulo, 2010.

${ }^{236}$ J. B. Debret. Voyage Pittoresque et Historique..., cit.p. I.. "poder nacional"
} 
passagem do governo de origem portuguesa para um de natureza totalmente "brasileira".

A nacionalidade em Debret incluía, portanto, os portugueses que, a partir da interação com o índio, depois com o africano e, por sua vez, o "português enraizado no Brasil", conformou na figura do "brasileiro" o sentimento de pertencimento, essencial na configuração de uma nação, principalmente para aqueles países que saíram da condição de colônia e cristalizaram em torno de uma identidade aglutinadora indivíduos que passaram a ser vinculados àquela entidade política. Esta ideia posteriormente exerceu grande influência na historiografia sobre a formação de uma identidade coletiva referente aos luso americanos. De acordo com esta produção, no espaço colonial foram sendo criadas novas condições para se ultrapassar os limites impostos pela Metrópole, mostrando-se um cenário favorável às novas formas de articulação identitária: as disputas de posições, que antes se davam apenas na esfera local, teriam permitido a geração de vocábulos políticos com novos ingredientes. A identificação de uma identidade luso americana já existente, nos quatorze anos que antecederam a independência, foi reforçada e politizada pela transformação do Brasil em sede da monarquia, e foi nesta mesma identidade que os acontecimentos políticos encontram um locus de definição de projeto de separação política da América portuguesa de sua metrópole. $^{237}$

O estabelecimento da corte no Rio de Janeiro também foi o aspecto analisado por Saint-Hilaire com relação ao suposto despotismo dos Vice-Reis do Brasil. Para ele, o sistema monárquico veio substituir a arbitrariedade imposta às capitanias. No entanto, se a transferência do centro de governo para o Brasil emancipou o país, segundo o viajante, o governo não soube aplicar as instituições uniformes e monárquicas de forma eficiente, não havendo harmonia no conjunto da administração, o que o faria encontrar, ainda pela frente, muitos embaraços. Antes da revolução que mudou o aspecto do país, termo utilizado pelo viajante para se referir às profundas mudanças vivenciadas pelo Brasil no início do século XIX, apontava que a autoridade dos capitães generais era quase ilimitada, ao mesmo tempo civil e militar. Eram escolhidos para governar grandes terras, e estando livres de qualquer vigilância, saudosos dos prazeres de uma grande capital, cheios de desprezo pela região que governavam e, principalmente, sem ter

${ }^{237}$ J. P. G. Pimenta. Portugueses, americanos, brasileiros..., cit. 
pessoas iguais com quem tratar, viviam rodeados de bajuladores e de escravos, entregando-se com frequência a todos os tipos de caprichos do despotismo. ${ }^{238}$

Tendo observado de perto a forma tirânica como os capitães generais supostamente procediam com relação a seus subordinados no tempo em que aqui esteve, afirmava ser o despotismo tão natural aos administradores do Brasil que para serem respeitados os capitães mantinham-se à grande distância de seus administrados e nenhuma relação além das exigidas pelas necessidades eram estabelecidas. ${ }^{239} \mathrm{Se}$ a entrada dos franceses em Lisboa e a chegada da corte ao Rio de Janeiro teriam feito com que o Brasil se emancipasse, para Debret os avanços pararam por aí. Apesar das mudanças para melhor no sistema de governo, a acumulação de tantas tarefas por uma só cabeça continuava a ser um grande mal para Brasil ${ }^{240}$

De modo geral, não teria havido ainda grandes mudanças no interior do país, apesar de Debret conceber que belas esperanças estavam previstas para o futuro dos "brasileiros": faltavam ainda reformas rápidas em regiões de população pouco densa e ignorante. ${ }^{241} \mathrm{O}$ conjunto das províncias que não apresentava homogeneidade no sistema colonial do Brasil antes que a presença da Monarquia estimulasse a união das partes do país, que para se fortalecer carecia das instruções que a população ainda não tinha conquistado, e após a chegada de D. João o interesse em garantir as melhorias, garantiria também a unidade do país.

Seguindo um raciocínio comum entre os viajantes analisados, Ferdinand Denis afirmava ter sido 1808 o ano que teria aberto aos habitantes do Brasil uma nova era de civilização e progresso: promulgou-se alvará que estimulou os diversos gêneros de indústria manufatureira e comercial, estabeleceu-se uma imprensa no Rio de Janeiro, o afluxo dos estrangeiros permitiu que o Brasil deixasse de ter aspecto de colônia. A mudança mais desejada teria se efetuado em 1815, segundo ele, que teria feito cessar a posição secundária do Brasil na hierarquia política. ${ }^{242}$ Porém, neste novo movimento, observava o viajante, na emancipação intelectual do país, a corte teria tido menos influência do que se poderia pensar num primeiro momento, trazendo antes todos seus

\footnotetext{
${ }^{238}$ August de Saint-Hilaire. Voyage dans les provinces de Rio de Janeiro et de Minas Gerais, Paris, Grimbert et dorez, 1830. p.354-355. Os trechos traduzidos em nota formam extraídos da seguinte edição:. Viagem pelas províncias do Rio de Janeiro e Minas Geraes. Trad. Clado Ribeiro de Lessa. São Paulo: Companhia Editora Nacional, 1938.

${ }^{239}$ A. Saint-Hilaire. Voyage dans les provinces..., cit. p.356-357.

${ }^{240}$ Ibidem, p. 356.

${ }^{241}$ Ibidem, p. ix.

${ }^{242}$ Ferdinand Denis. Brésil. par M. Ferdinand Denis; Colombie et Guyanes, Par M. C. Famin. Paris, Firmin Didot frères, éditeurs, MDCCCXXXVII .p. 113-114.
} 
vícios para o novo ambiente político do Brasil. Ainda assim, observava Denis, que a população mais instruída teria compreendido de onde teriam vindo os melhoramentos reais operados no Brasil e que foi graças às relações estabelecidas com negociantes ingleses e franceses que os conhecimentos necessários ao aumento da indústria poderiam ser adquiridos, caráter ativo da luta empreendida, nem sempre em proveito de Portugal. $^{243}$

Apesar de todos os melhoramentos visíveis no país, Denis compartilhava muitos aspectos com Saint-Hilaire a respeito da nação que seria constituída no Brasil. ${ }^{244}$ Escrevia Denis que o pacto proposto à nação jurado por D. Pedro ao ser coroado imperador manifestava intenções generosas e sinceras; no entanto, a população tinha características muito heterogêneas para que o imperador tivesse adivinhado todas suas necessidades. Em concordância com Saint-Hilaire, na ausência de homogeneidade entre os habitantes do Brasil, Denis também apontava que apesar disto a população, de um modo geral, era dotada de costumes afáveis, generosos e hospitaleiros ${ }^{245}$, opinião, aliás, bem comum nos relatos de viagem analisados.

Tanto para Denis quanto para Sait-Hilaire, a sociedade plenamente constituída não existia no Brasil, podendo, ao contrário, se descobrir com dificuldades apenas alguns elementos de sociabilidade. Concordavam, portanto, que a educação moral e política ainda ausente entre a população seria subsídio essencial na união dos habitantes e para tanto era necessário que se conhecesse melhor o Brasil. Afirmava Denis que era provável que mais uma vez os legisladores tivessem estado em situação de perceber este vício fundamental de organização. ${ }^{246}$ A percepção de que um sistema de governo de modelo europeu não daria conta da complexidade social do Brasil é um aspecto que deve ser ressaltado nos autores por induzir à conclusão de que para as especificidades do Brasil era necessário um sistema de governo que atendesse à heterogeneidade da população. $^{247}$

A mudança de residência da corte ao Brasil trazia consigo o projeto imperial lusitano, unindo, ao menos em projeto, as elites coloniais e propagando o expansionismo territorial. Contudo, na prática, a diversidade encontrada no país significava, frente à crise enfrentada pelo império português, um desafio à manutenção

\footnotetext{
${ }^{243}$ Ibidem, p. 114.

${ }^{244}$ K. M. Lisboa analisa os mesmos aspectos em Olhares estrangeiros..., cit. p. 275-276.

${ }^{245}$ F. Denis. Brésil..., cit. p. 163.

${ }^{246}$ Ibidem, p. 164.

${ }^{247}$ K. M. Lisboa. Olhares estrangeiros..., cit. p. 276.
} 
da velha ordem, monárquica, escravagista, com território ainda em consolidação, com a articulação de novos princípios, tais como as questões identitárias que se faziam presente agora em perspectivas diferenciadas. $\mathrm{O}$ processo de dominação do monarca residia na autoridade que este exercia sobre sua casa e corte ${ }^{248}$, e a mudança na simbologia verificada na transferência para o Brasil consistiu consequentemente na mudança também da forma de súditos e autoridade monárquica se relacionarem.

Considerando a dimensão geográfica do processo de construção de uma ideia de Brasil, Schwartz bem notava que os ingleses tinham razão ao falar em "Brasis" no século XVII e XVIII, pois havia de fato mais de uma colônia. ${ }^{249}$ Isto tinha efeito também na posição social dos mestiços que mudava de status na medida em que o relacionamento dos portugueses com índios e africanos mudava devido às transformações ocorridas na sociedade colonial. ${ }^{250}$ Tanto as diferenças regionais quanto as diferenças na composição social do Brasil foram notados pelos viajantes, que atribuíam a tais aspectos, somados aos acontecimentos históricos de que foram testemunhas, as variáveis do processo de formação nacional no Brasil.

Isso tudo compõe este complexo processo que, entre tantas possibilidades e projetos, teve nos estrangeiros força de composição de uma identidade, futuramente de cunho nacional. Enquanto alguns salientaram a diferença da composição social do Brasil, apontando mecanismos que reuniriam os habitantes do país num mesmo corpo, outros apontaram a falta de similaridade da população e os esforços de manutenção de uma ordem que unia sob a monarquia, em oposição aos desmandos do Antigo Regime, uma ideia de Brasil. Mas, para todos os efeitos, todos os viajantes analisados buscaram entender essa diversidade, mesmo na dispersão.

\footnotetext{
${ }^{248}$ Norbert Elias. A sociedade de corte. Lisboa: Estampa,1987. p. 20.

249 "Na costa entre Pernambuco e Rio de Janeiro, onde haviam sido criadas colônias de exportação, o estabelecimento de colonos europeus era intenso, as instituições reaise o governo local estavam presentes, e uma imensa massa de população servil importada constituía a principal força de trabalho [...] No inteiro e nas periferias da colônia, a composição da sociedade e a estrutura de governo eram diferentes, ou, pelo menos, a cronologia separava essas regiões do Brasil. O estado do Maranhão era, essencialmente, uma colônia independente (1621-1777) com seu governador e seu bispo reportando diretamente a Lisboa, em vez de Salvador [...] Ali a população era rarefeita, o número de europeus fora de Belém ou São Luís muito pequeno, e a maioria de seus habitantes era de pessoas indígenas ou caboclas, de origem mista. As capitanias do Sul também haviam sido tratadas como uma região separada e, embora as tentativas formais de se criar um governo à parte, do Rio de Janeiro para o sul, tivessem fracassado (1573-1578, 16081612), os governadores residentes na Bahia tinham pouco controle sobre o Sul. São Paulo permaneceu uma área rustica até bem avançado o século XVIII [...] A organização social variava, então, conforme a época e o lugar, assim como variava o número relativo de europeus, africanos e pessoas indígenas de origens diversas." S. Schwartz. "Gente da terra braziliense da nasção"... cit., p. 112-113. Sobre questões territoriais no governo joanino ver F. M. Lahuerta. Geografias em movimento: território e centralidade no Rio de Janeiro Joanino (1808-1821). 2009. Dissertação de mestrado - FFLCH-USP. São Paulo.

${ }^{250}$ Stuart Schwartz. "Gente da terra braziliense..., cit. p. 113.
} 


\section{2 - Os viajantes e os "brasileiros"}

Com as atenções voltadas para a América nas primeiras décadas do século XIX, a politização das identidades coletivas e o sentimento de pertencer a uma nação portuguesa reverberaram nos meandros sócio-políticos do continente, sendo a América portuguesa palco de transformações identitárias complexas que culminariam mais tarde no "ser brasileiro". As entidades políticas envoltas nesta questão nacional legaram aos habitantes dos domínios ibéricos ressignificações em torno das diversas identidades coletivas que permeavam o mundo luso americano de então, do qual tratamos. ${ }^{251} \mathrm{E}$ os viajantes estrangeiros, agentes históricos deste processo, constituem rico manancial de possibilidades de percepção deste "outro" que, por seu turno, incentivou a criação de condições para o surgimento de uma identidade.

Partimos da hipótese de que os viajantes estrangeiros foram os primeiros entre os europeus a utilizarem de modo mais definido o termo "brasileiro", e que a formação e divulgação de vocábulos definidores de adesão à porção americana do império português feita por eles guardam relação com o processo de formação da nação brasileira. Ao descrever as paisagens e costumes da gente e ao veicularem vocábulos que dissessem respeito a estas descrições, concebemos que tais viajantes contribuíram em delinear, por meio de seus textos, os contornos de uma futura identidade, de certo modo "acelerando" este processo de identificação nacional.

Cada viajante, apesar da visão específica da população do Brasil e quem eram os indivíduos referidos no termo "brasileiro", ressaltava a população como fator importante na configuração da sociedade luso americana de então. Analisaremos agora como os viajantes britânicos e franceses elencados nesta pesquisa definiram tal expressão identitária por diversos meios, indo desde definições imprecisas que salientavam tipos específicos de portugueses, até variações que se adequavam ao momento histórico a partir do qual observavam e escreviam.

\section{Os britânicos e os "brasileiros"}

A presença da cultura britânica no desenvolvimento do Brasil não é algo que possa ser ignorado no processo de compreensão do homem "brasileiro" de acordo com

\footnotetext{
${ }^{251}$ Jancsó\& Pimenta. Peças de um mosaico ..., cit.
} 
um dos pesquisadores que mais exaustivamente estudou os ingleses no Brasil. Segundo Gilberto Freyre, "os ingleses, quase tanto quanto os franceses, madrugaram, sob forma de piratas, aventureiros e negociantes, nas praias da América tropical descobertas por portugueses e espanhóis. E distanciando-se dos franceses, por longos anos seus rivais, os ingleses acabaram alcançando entre nós uma preponderância econômica que, ostensiva nos dias de D. João VI regente e depois rei - quando aquela preponderância assumiu aspectos francamente imperialistas e não apenas imperiais - acentuou-se de 1835 a 1912", preponderância esta que só declinou lentamente pela expansão norteamericana e minada pela alemã. ${ }^{252}$

Do ponto de vista da integração de culturas na formação desse homem, a presença estrangeira no Brasil adquiriu relevância na formação dessa sociedade de caráter múltiplo, "ainda que confusa, em suas heranças em suas técnicas de desenvolvimento, em seus valores e estilo de vida, moral e intelectual, estética e moral." ${ }^{253}$ No que tange às identidades, podemos admitir que a compreensão dos "brasileiros" aos olhos dos britânicos foi resultado de tal dominação, e como observa Freyre, não poderia deixar de produzir efeitos em outras zonas ou esferas de influências. Assim, ao ofertarem vocábulos e características relacionados aos habitantes do Brasil, entendemos que os estrangeiros e, principalmente os britânicos, contribuíram na formação do "brasileiro" como identidade aglutinadora de determinados indivíduos.

Quase que invariavelmente, as exposições feitas pelos viajantes sobre determinadas localidades e seus habitantes, ainda que espaços específicos dentro do todo, acabavam por angariar definições que fariam referência de modo geral a todos os habitantes, constituindo, assim, traços que de certa forma uniam as partes desconexas da América portuguesa, ao menos, no plano dos discursos, das linguagens e dos conceitos veiculados à época.

Percebemos estes traços dos habitantes de regiões específicas na narrativa de Mawe. O autor faz apropriações de elementos constituintes das feições dos "paulistas" na análise de outros grupos humanos pertencentes à porção americana do império português. A predileção pelos habitantes de São Paulo é algo que não passa despercebido no autor, que menciona o quanto eram enaltecidos por todo o Brasil por sua dignidade de caráter e que "the appellation of Paulista is considered by all the

\footnotetext{
${ }^{252}$ Gilberto Freyre. Ingleses no Brasil. Rio de Janeiro: José Olímpio, 1942. p. 11-12.

${ }^{253}$ Ibidem, p. 4.
} 
females here as a great honour" ${ }^{254}$ Incompatível com as impressões feitas por viajantes anteriores, a opinião de Mawe sobre o "character of the Paulistas" tal como o observou, não coincidia com o barbarismo e a falta de hospitalidade mencionados por seus antecessores. Seguiu dizendo sobre a cidade de São Paulo:

"its first foundation never acknowledged any other sovereignty than that of Portugal. The veracity of this account is further supported by the predominant character of the Paulistas, who, far from inheriting the obloquy which an ancestry of rogues and vagabonds would have entailed upon them, have long been famed throughout all Brazil for their probity, their industry, and the mildness oh their manners." 255

O viajante buscou também no passado da colônia esta inclinação de caráter dos habitantes do Brasil, ao narrar a origem de um lugar que foi considerado o mais rico do mundo com apenas vinte anos de fundação. ${ }^{256}$ Pautado em informações recebidas de habitantes mais instruídos, segundo ele, Vila Rica, antigamente tão opulenta em riqueza, teria sido descoberta pelos paulistas, "who, of all the colonists in Brazil, retained the largest share of that ardente and indefatigable zeal for descovery which characterized the Lusitanians of former days."257 Mawe notava nos "aventureiros", dos quais descendiam os paulistas e a quem confere tantas qualidades, o traço mais positivo dos habitantes do Brasil.

A quantidade de usos do vocábulo "português" nas descrições feitas por Mawe dos que aqui habitavam é muito mais frequente que a menção ao termo "brasileiro", independentemente deste ser considerado português nascido na Europa ou na América,

\footnotetext{
${ }^{254} \mathrm{~J}$. Mawe. Travels in the interior..., cit.. p. 82. "O ser paulista é considerado aqui, por todas as senhoras, grande honra.".

${ }^{255}$ Ibidem, p. 87.“[...] a cidade, desde sua fundação, não reconheceu nenhuma outra soberania, senão a de Portugal. A verdade desta informação é mais tarde confirmada pelo caráter predominante dos paulistas, que, longe de herdarem a infâmia, vínculo natural de descendentes de velhacos e vagabundos, se tornaram conhecidos, em todo o Brasil, pela sua probidade, indústria e afabilidade de maneiras."

${ }^{256} \mathrm{Em}$ contrapartida ao auge da mineração na região das minas, análises sobre o comportamento do Estado português com relação à decadência do ouro podem ser vistas em Antônio de Barros Castro. "A região das Minas. Retrocesso e dispersão após a crise". 7 ensaios sobre a economia brasileira. vol. II. 3 ed. Rio de Janeiro: Forense-Universitária, 1980.; Maria Yedda Leite Linhares. O Brasil no século XVIII e a idade do ouro. In: Seminário Sobre a Cultura Mineira no Período Colonial. Belo Horizonte: Conselho Estadual de Cultura de Minas Gerais, 1979. p. 147-71.; Laura de Mello e Souza. Desclassificados do ouro: a pobreza mineira no século XVIII. Rio de Janeiro: Graal, 1982.

${ }^{257}$ John Mawe. Travels in the interior..., cit. p. 171.“" [...] dentre todos os desbravadores do Brasil, foram os que mais conservaram o espírito empreendedor e o zelo ardente e infatigável que caracterizavam os portugueses de outrora."
} 
ou ainda se as classes mestiças incluíam-se nesta circunscrição ou não. O fato é que, apesar da pouca distinção do viajante com relação a qual grupo cada um dos dois termos se referiria, natural para o momento no qual a narrativa é feita, o emprego da palavra "brasileiro", mesmo usado em poucas ocasiões, já trazia para o universo simbólico dos viajantes um elemento novo.

Passagem ilustrativa de tal disposição de vocábulos está na viagem que ele empreenderia à província das Minas, excursão que em suas palavras não tinha sido feita por nenhum outro "Englishmen". ${ }^{258}$ Chegando a Cebola em 1809, o viajante teve do Capitão José Antônio Barbosa a impressão de descontentamento com a licença dada pela Sua Alteza Real para que estrangeiros viajassem pelo interior do país: "Portugueze of the old school [...] [he] treated us with a constrained civility which showed that he thought we were come about no good. ${ }^{, 259}$ Termo que para outros viajantes significaria descendentes dos primeiros colonizadores do Brasil, sinônimo de "brasileiro", em Mawe este termo poderia significar "luso americano" ou mesmo "português", expressões identitárias também importantes na emulação de sentimentos que fizessem alusão ao pertencimento a um grupo humano específico, mas que, em parte pelo momento em que escreve, não estão detalhadamente diferenciadas pelo viajante. Até 1811, ano em que Mawe deixa o Brasil, a conjuntura política, que futuramente seria condicionante de uma percepção mais apurada das identidades coletivas e sua politização, como a elevação do Brasil a Reino, não oferecia condições históricas para uma transformação nas formas dos habitantes da América portuguesa se relacionar uns com os outros e mesmo com os portugueses europeus, assim como a de se imporem enquanto "brasileiros" diante do estrangeiro.

Ainda que o termo não tenha tido destaque nos escritos do viajante, a conformação de características gerais dos indivíduos que analiticamente poderiam ser entendidos como "brasileiros" está colocada em Mawe a partir da descrição dos "crioulos". ${ }^{260}$ Vivendo sempre na indolência e na ignorância, não teriam estes meios de compreender a vida laboriosa, ao mesmo tempo em que tinham nos negros sua principal propriedade aos quais dispensavam má direção na produção e, consequentemente, maus resultados nos lucros do trabalho. Com o passar dos anos os "crioulos" tornavam-se completamente inativos, segundo o viajante, continuando a viver na mesma ociosidade

\footnotetext{
${ }^{258}$ Ibidem,p. 141.

${ }^{259}$ Ibidem, p. 144. "Português da velha escola [...] [ele] nos tratou com uma polidez constrangida, que dava a entender parecer-lhe não termos vindo com boas intenções [...]"

260 "Creolian", na edição em inglês: sentido de "português nascido na América".
} 
e negligência de sempre. Segundo Mawe, esta degeneração, para ele deplorável, constituía "almost the universal characteristic of the descendants of the original settlers". ${ }^{261}$ Se não há definição clara de quem, do seu ponto de vista, seriam os "brasileiros", as características do "crioulo" estariam mais perto de uma definição totalizadora de um grupo específico dentro do quadro das múltiplas identidades relacionadas na América portuguesa ao genuíno habitante do Brasil.

Ainda sobre a população de São Paulo, Mawe analisou que, em geral, os homens de alta categoria costumavam-se vestir muito bem e que em sociedade eram suaves e corteses; procuravam sempre agradar e eram sempre muito predispostos à jovialidade. Já as classes inferiores, comparadas as de outras cidades coloniais, encontravam-se num estado de civilização bastante adiantado. ${ }^{262}$ A grande afluência de estrangeiros teria trazido pequenas modificações observadas nos habitantes do Rio de Janeiro com relação aos de São Paulo, que, segundo Mawe, possuíam os mesmos hábitos e maneiras, mencionando, sobre aqueles, que "the Portugueze are in general rather punctilious and reserved in admitting a Foreigner to their families parties; but have on cereceived him, they are open anda hospitable [...] In their mixed assemblies the utmost gaiety prevails, and is seasoned by that finished politeness for which the Portugueze are generally distinguished." ${ }^{263}$ Portanto, percebemos que o autor faz uso do vocábulo "português" para se referir tanto aos habitantes do Rio de Janeiro quanto aos de São Paulo, economizando nas variações de expressões que fizessem alusão a um grupo pertencente ao espaço geográfico compreendido na palavra "Brasil".

Além destes aspectos, podemos sublinhar a coexistência de identidades coletivas no Brasil antes do movimento político que desembocaria na formação do Estado brasileiro $^{264}$, apontando oposição entre as províncias, diferenciação acentuada por questões que no relato de Mawe se dão por vias econômicas. Em observações sobre o comércio da Inglaterra com o Brasil, o viajante apontava as consequências produzidas

\footnotetext{
${ }^{261}$ Ibidem, p. 176. "o traço mais característico dos descendentes dos primeiros colonos".

${ }^{262}$ Ibidem, p. 83.

${ }^{263}$ Ibidem, p. 104-105. "Os portugueses são, em geral, escrupulosos e reservado em admitir estrangeiros às suas reuniões familiares; mas, recebendo-o uma vez, mostram-se francos e hospitaleiros [...]Nas reuniões mistas, requintada por aquela extrema delicadeza em que geral caracteriza os portugueses."

${ }^{264}$ Algumas indicações sobre o assunto estão em J. P. Pimenta. Portugueses, americanos, brasileiros..., cit.; Ana Rosa Cloclet da Silva. Identidades em construção: o processo de politização das identidades coletivas em Minas Gerais, de 1792 a 1831. Almanack Braziliense (Online), São Paulo, v.1, 2005.; 1808 e seus impactos no processo de politização das identidades coletivas: Minas Gerais (1795-1831). Revista de História (Online), São Paulo, 2008.; uma análise sobre as identidades na América inglesa, Jack P. Greene. Reformulando a identidade inglesa na América britânica colonial: adaptação cultural e experiência provincial na construção de identidades corporativas. Almanack Braziliense (Online), São Paulo, v. 4, 2006.
} 
no Rio de Janeiro e em todo o país pelas especulações excessivas que seus compatriotas praticaram após a chegada da corte. ${ }^{265} \mathrm{O}$ comércio ilícito de madeira de tinturaria no Rio, por exemplo, colocado em prática em grande medida pelas especulações de "maugosto" que acometeram grandemente a cidade por esta época, teriam dado prejuízos à Pernambuco, onde tal comércio era permitido por contrato. ${ }^{266} \mathrm{O}$ volume de mercadoria era tão grande que, segundo ele, a baía de Guanabara não tardou a se encher de mercadorias, ao ponto dos habitantes do Rio de Janeiro, mais particularmente os "Creolians" e os "strangers from the interior", pensarem que elas estivessem ali por generosidade dos ingleses, "who strewed the beach to a great extent with articles for which their own countrymen had here to forecharged them such high price. ${ }^{, 267} \mathrm{O}$ desdobramento de uma trajetória coletiva a partir da conquista e colonização da América propiciou a matriz das novas identidades coletivas emergentes no cenário colonial. ${ }^{268} \mathrm{E}$ a expressão "estrangeiros do interior" aponta para estas múltiplas identidades que coexistiam dentro do espaço geográfico denominado Brasil, mas que nem por isso estiveram sempre relacionadas ao conjunto de províncias que compunham este território.

Lembrando que as contradições internas do império português se acentuavam de um relato para o outro, dependendo do período em que a narrativa foi pensada e escrita, em comparação à Mawe e aos outros britânicos analisados nesta pesquisa, Henry Koster, que esteve no Brasil de 1809 a 1816, é quem de modo mais contundente diferencia "português" e "brasileiro", especificando os usos dados aos vocábulos. As descrições sobre os habitantes do Brasil começam com a explicação do autor a respeito de quem eram os "Portuguese" e os "Brazilians": o primeiro termo teria uso exclusivamente para se tratar de "Europeans of this nation", enquanto "the Word Brazilian" faria referência às pessoas brancas nascidas no Brasil. ${ }^{269}$ Percebe-se que o viajante não incluía outras pessoas que não as de descendência portuguesa nascidas no Brasil na classe dos "brasileiros", excluindo-se deste grupo inclusive os mulatos, ainda que nascidos no país. Esta indicação tem alguma influência na caracterização que este

\footnotetext{
${ }^{265}$ J. Mawe. Travels in the interior..., cit. p. 323.

${ }^{266}$ Ibidem, p. 327-328.

${ }^{267}$ Ibidem, p. 324. "[...] que cobriam a praia, por uma longa extensão, com produtos pelos quais os seus próprios compatriotas, até então, cobravam preços tão elevados."

${ }^{268}$ I. Jancsó \&J. P. G. Pimenta. Peças de um mosaico.....cit.

${ }^{269}$ H. Koster. Travels in Brazil..., cit. p. 7. "Português", "Brasileiros", "Europeus desta nação", "palavra brasileira".
} 
fez dos chamados "brasileiros", já que se tratavam de pessoas brancas, estabelecendo, desta forma, lugar de destaque na hierarquia constituinte de uma sociedade colonial. ${ }^{270}$

A seguinte passagem é reveladora da perspectiva adotada: convidado a passar um domingo com uma família constituída de pai, mãe, filho e filha, sendo todos "brasileiros", observava que a moça tinha tez não mais morena que as portuguesas em geral e embora tivesse visto outras moças bonitas, esta poderia ser indicada como "a very fair sample of the White Brazilian female" ${ }^{271}$. No entanto, era entre as mulheres de cor que se poderiam fixar os tipos mais belos, segundo ele, as que teriam maior atividade de espírito e de corpo e as que seriam mais adaptadas ao clima, afirmando que os mestiços pareciam ser os verdadeiros habitantes do país:

"Their features too are often good, and even the colour, which in European climates is disagreeable, appears to appertain to that in which it more naturally exists; but this bar to Europeans ideas of beauty set aside, finer specimens of the human form cannot be found than among the mullato females whom I have seen." 272

Ainda que os mestiços, especialmente as mulheres, tivessem lugar de destaque na sua análise, a adaptabilidade destes indivíduos ao ambiente em que viviam não garantia a eles a posição de pertencimento ao Brasil, enquanto espaço associativo de "brasileiros", ou seja, de pessoas brancas. ${ }^{273}$

As diferenciações ainda estão voltadas em Koster, entre outros aspectos, pela atividade exercida pelos habitantes. Ao visitar algumas famílias "brasileiras" e descrevê-las no intuito de dar uma ideia geral da sociedade que encontrou em Pernambuco, advertia que eles eram "Portugueze families, of which the chiefis in office,

\footnotetext{
${ }^{270}$ Sobre a origem e o papel das elites sociais luso americanas na formação da sociedade colonial ver M. B. N. Silva. Ser nobre na colônia. São Paulo: UNESP, 2005.; . Cultura e Sociedade no Rio de Janeiro (1808-1821). 2 ed. São Paulo: Nacional, 1978. ; Roberta G. Stumpf. Nobrezas na América portuguesa: notas sobre as estratégias de enobrecimento na capitania de Minas Gerais. Almanack Guarulhos (Online).v.1, 2011. p. 119-136.

${ }^{271}$ H. Koster. Travels in Brazil..., cit. p. 24. “[...] o tipo branco de mulher brasileira.”. Uma análise sobre as raízes da desigualdade no Brasil

${ }^{272}$ Ibidem, p. 24."As feições são frequentemente boas, e a cor, mesmo quando é desagradável nos climas europeus, não parece mal nesse ambiente, mas o padrão de ideia de beleza, segundo as convenções da Europa, os mais lindos espécimes de forma humana, tendo-os visto entre as mulatas."

${ }^{273}$ Debate clássico sobre as relações raciais no Brasil pode ser visto em F. Fernandes. A integração do negro..., cit.. Motivo de grande controvérsia no universo acadêmico, G. Freyre apresenta uma análise sobre a natureza e o papel do negro, do índio e do mestiço na colonização portuguesa no Brasil em Casagrande e Senzala..., cit.
} 
or Brazilian planter who are wealthy" 274 e que o filho ou filha, educados sob a cautela de um padre secular, ficavam embebidos de ideias liberais e acabavam por adquirir gosto pela sociedade racional, ao passo que as mulheres dessas famílias sempre ostentavam importância para serem tratadas com distinção. Ao contrário, os comerciantes, com raras exceções, eram os que viviam retraídos, tinham vindo de Portugal e fizeram fortuna nos negócios e acabavam por se casar no Brasil, dos quais a maioria continuava a viver, segundo ele, como se não possuíssem riqueza suficiente e não abandonavam seus hábitos de retraimento ou pelo menos não se persuadiam a abandoná-los. ${ }^{275}$ Os "brasileiros" e "portugueses" nesta análise estão reunidos num mesmo grupo e o que os diferencia é a posição que cada um ocupa na sociedade.

Percebem-se gradações no pertencimento ao grupo dos "brasileiros" e "portugueses”, em uma análise que está geralmente pautada nos hábitos das pessoas. Para Koster, entre a parte da população que deixou seu país para fazer fortuna no Brasil, ou seja, "portugueses", a introdução dos melhoramentos advindos com a nova situação política era quase impossível. Exemplo deste comportamento ele teria testemunhado em jantar com um proprietário de engenho que se dizia português, no qual não era sequer permitida a troca de olhares entre homens e mulheres, sendo servido o jantar a estas em aposento adjacente à sala principal. Muitos "brasileiros", segundo Koster, mesmo que de classe superior, também seguiam costumes de sujeição e reclusão, mas ao terem alguma comunicação com a cidade, viam depressa que maneiras mais civilizadas eram preferíveis e rapidamente adquiriam hábitos de polidez. ${ }^{276}$

Alguns costumes adquiridos pelos "brasileiros", observados por ele, em todos os grupos sociais, se ligavam aos da vida selvagem, como o ato de se banhar em um rio ou poço d'água, constituindo num dos maiores incômodos para um "brasileiro", segundo ele, não residir em local onde o costume pudesse ser colocado em prática. ${ }^{277}$ Os hábitos dos "brasileiros" e as melhorias a partir da interlocução com indivíduos de nacionalidades mais civilizadas faziam deles uma classe de gente que, não obstante a sua maior propensão a melhoramentos em comparação com os "portugueses", os colocavam numa posição senão de inferioridade, de "inocência" quanto aos hábitos da vida civilizada.

\footnotetext{
${ }^{274}$ H. Koster. Travels in Brazil..., cit.p. 28."São famílias de que é chefe, português e funcionário público, ou um brasileiro, rico agricultor."

${ }^{275}$ Ibidem, p. 28.

${ }^{276}$ Ibidem, p. 48.

${ }^{277}$ Ibidem, p. 94.
} 
Outra ocasião levou Koster a observar um costume não muito raro, embora causasse murmúrios quando acontecia: casamento entre uma menina branca, que falava desembaraçadamente, mostrando ter residido em lugar mais civilizado, filha de pequeno proprietário, apesar de encontrá-la morando em lugar remoto do sertão, por ocasião do enlace com um mulato rico, de feições escuras e aparentando ter quarenta anos de idade. ${ }^{278}$ As famílias dos ricos mulatos mostravam-se sempre desejosas, segundo ele, de desposar suas filhas com esses homens, embora o escolhido não tivesse situação definida, referindo-se provavelmente à condição social, determinante da posição que ocuparia na sociedade. Numa coletividade pautada pelo sistema escravista, fato que em muito influenciava na diferenciação das classes sociais, a dinamização da economia foi acompanhada da dinamização da estrutura social e envolvia indivíduos livres, escravos cativos e/ou alforriados, homens ou mulheres, brancos, negros, crioulos, mestiços ou mesmo os índios. ${ }^{279}$ A este respeito, e levando-se em conta as relações escravistas no Brasil, o universo cultural que se apresentava aos olhos dos viajantes era um universo hibrido e mestiço ${ }^{280}$, de certa forma justificando alguns costumes. Na visão de Koster, a cor dos filhos que nasceriam dessa união seria melhorada, além de deixar evidente a cautela e método dessa classe de homens em conseguir fortuna, mesmo começando com recursos mínimos. ${ }^{281}$

Esta opinião, que aos olhos de um europeu poderia causar indignação, em Koster não exprime, ao menos diretamente, qualquer linha de aversão. A inclinação dos mulatos, comentava, era para os brancos, e como não possuíam ligação com os indígenas, aqueles sentiam orgulho em não ter nada em comum com estes; no entanto, os mulatos eram, segundo ele,

\footnotetext{
${ }^{278}$ Ibidem, p. 100.

${ }^{279}$ Jener Cristiano Gonçalves, que estudou o ambiente jurídico de Minas Gerais no final do século XVIII e início do XIX, observa que "naquela sociedade, que se urbanizava rapidamente durante o século XVIII, esse trânsito foi marcado por conflitos, mas também, por acordos e negociações, trocas, convivências e coexistências e isso ajudou a forjar as relações sociais ali vivenciadas", pensando-se até recentemente, segundo ele, que "esse quadro teria fomentado as singularidades da capitania mineira, diferenciando-a das outras regiões da América portuguesa, da sociedade metropolitana e do império português." No entanto, constatou-se através das pesquisas a integração da região das Minas com o restante do império fundamentada pelo estatuto colonial "marcado pela pluralidade, o que ajuda a explicar sua sustentação em pontos tão longínquos e diversos."Jener C. Gonçalves. Justiça e direitos costumeiros: apelos judiciais de escravos, forros e livres em Minas Gerais (1716-1815). Dissertação de Mestrado. Belo Horizonte: Faculdade de Filosofia e Ciências Humanas da UFMG, 2006. p.14.

${ }^{280}$ Eduardo França Paiva. Escravidão e universo cultural na colônia. Minas Gerais 1716-1789. Belo horizonte: UFMG, 2001, p. 38.

${ }^{281}$ H. Koster. Travels in Brazil...., cit. p. 393.
} 
"conscious of their connection with men who are in a state of slavery, and that many persons even of their own colour are under these degraded circumstances; they have therefore always a feeling of inferiority in the company of white men, if these white men are wealthy and powerful [...] Still the inferiority which the mullato feels is more that which is produced by poverty than that which his colour has caused, for he will be equally respectful to a person of his own cast, who many happen to be rich."282

A observação de que a inferioridade sentida pelos mulatos provinha mais da pobreza do que pela cor da pele, ressalta a ideia de que a relação entre escravos e livres e a relação entre brancos e negros era muito mais complexa do que qualquer possível dicotomia que o sistema escravista pudesse sugerir. Isto porque muito além do efeito das manumissões cumulativas ao longo do território luso americano ${ }^{283}$, os laços entre os escravos e os indivíduos livres (e brancos) eram frequentes, influenciando nas gradações de cor e envolvendo a melhoria do status social de parte da população.

Conquanto a distinção entre "brasileiros" e "portugueses" seja dada a partir de categorias que envolvem variáveis como cor e posição social, quando se trata da população livre, incluindo-se aí tanto os ricos como os pobres numa apreciação geral da população da região do Brasil onde residiu, a análise de Koster ganha contornos mais complexos, dotando as categorias utilizadas de outras variáveis que vão além da posição social, cor da pele e/ou local de nascimento. Está envolvida aí a posição das classes mestiças na sociedade, que é explicada comparativamente aos privilégios concedidos a elas na América hispânica: a insuficiência da população de Portugal para colocar em prática os planos administrativos do Governo na América foi o que, segundo Koster, teria salvado as possessões das revoltas entre os habitantes "creole whites" e os homens de cor, situação vivida pelas vizinhanças coloniais da Espanha: a partir das disputas entre os "descendants of Europeans, born in South America" e os "natives of Old Spain", advindas com a crise peninsular, outras lutas destruidoras se fariam presentes, agora entre os primeiros e seus patrícios, de castas mestiçadas, devido ao apelo que os

${ }^{282}$ Ibidem, p. 390-391. "conscientes de sua filiação com os homens que continuam em estado de escravidão e muitas pessoas de sua própria cor jazem sob essa degradante circunstância, daí provindo o sentimento de inferioridade na companhia dos brancos, se esses brancos são ricos e poderosos [...] De mais, essa inferioridade que o mulato sente é mais produzida pela pobreza do que pela sua pele, e ele mantém a mesma posição respeitosa para com uma pessoa de sua casta que tenha felicidade de ser rica."

${ }^{283}$ Rebeca Scott J. Exploring the meaning of freedom: post emancipation societies in comparative perspective. In: Rebeca Scott J. (org.). The abolition of slavery and aftermath of emancipation in Brazil.Duke University Press, 1988.p. 407. 
“creole whites" fizeram à população de princípios abstratos de governo, tão sedutores na teoria, mas difíceis na execução, acarretando destruições. ${ }^{284}$ Percebemos que as distinções de classe entre os espanhóis estão os mestiços em posição inferior tanto com relação aos "espanhóis americanos" quanto aos "espanhóis europeus".

Na América portuguesa, as circunstâncias não admitiam esta divisão de "castas", nem distinções degradadoras, segundo Koster, presentes em todas as outras nações na administração de suas colônias, na medida em que Portugal não possuía população suficiente para tais planos. Desta forma, Koster observava que

"Adventures left their own country to settle in the New World, who were literally adventures; for they had not any settled plans of life; and they were without families. Persons of established habits, who had the wish to follow any of the ordinary means of gaining a livelihood, found employment at home [país]; neither could Portugal spare them, nor did they wish to leave their native soil. There was no superabundance of population, and therefore every man might find occupation at home [pátria], if he had steadiness to look for it; there was no division in political or religious opinion; there was no necessity for emigration, save that which was urged by crimes." 285

As expressões at home sublinhadas no trecho acima, traduzidas para o português na edição de 1942 como "país" e "pátria", respectivamente, mas que no texto podem ser consideradas sinônimas, apontam alguma relevância no que diz respeito ao pertencimento ao local de origem dos "aventureiros" que vieram ao Brasil, fossem premidos pelo crime ou em busca de riqueza. De certa forma, o português não teria motivos para se submeter ao entrelaçamento das castas que estariam sujeitos os que se estabelecessem no Brasil, e "at home" confere ao discurso de Koster uma aproximação com o europeu, moderado no seu modo de viver, bem educado, diferente dos que se

\footnotetext{
${ }^{284} \mathrm{H}$. Koster. Travels in Brazil.., cit.p.384.“descendentes dos europeus, nascidos na América do Sul”, "nativos da velha Espanha", "brancos americanos".

${ }^{285}$ Ibidem, p. 385. Grifos meus. "Aventureiros deixaram seus países para residir no Novo Mundo, e eram verdadeiramente aventureiros, não tendo nenhuma orientação de vida e de ordem, e despossuídos de família. As pessoas de hábitos morigerados, que desejavam garantir sua subsistência pelos meios ordinários, encontravam trabalho no próprio país e Portugal pensava em poupar-se, sem cálculos de abandonar a terra natal. Não havia superabundância na população e, logicamente, cada qual podia encontrar ocupação na própria pátria se quisesse trabalhar. Não havia divergência nas opiniões políticas ou religiosas. Não havia, desta forma, necessidade de emigrar senão premido pelo crime.”
} 
dispunham a viver na colônia em meio a formas de vida desregradas e num ambiente adverso. A generalidade dos homens que embarcou nas expedições ao Brasil, continuava Koster, desacompanhada de mulheres brancas, casava-se ou ligava-se irregularmente às mulheres indígenas e depois africanas, e com o passar do tempo, no curso da geração seguinte, desposavam mulheres de raças mestiças. Este costume foi, segundo o viajante, silenciado diante da lei, dissipando toda a ideia de degradação que tal ato pudesse acarretar. Ainda assim, a superioridade dos Europeus, que na América hispânica teria desencadeado guerra de poder destruidor entre as castas, na América portuguesa, diante da intensa miscigenação submetida por necessidade, ainda que não fosse esse o pensamento promovido pela Metrópole, não desapareceu totalmente, determinando alguns privilégios que, ademais, distanciariam a "população de cor" dos cargos administrativos e eclesiásticos. ${ }^{286}$

No entanto, e a despeito da posição conferida aos mestiços mesmo com todas as circunstâncias apontadas, a brandura da lei teria conferido a esta classe ganho considerável de terreno. Esta observação dada pelo viajante nos direciona à complexificação das distinções sociais da América portuguesa que confere à análise de Koster algumas incongruências. Algumas delas podem ser observadas na classificação da população livre dada pelo viajante, na qual estão presentes gradações de cor na constituição da classe dos "brasileiros”, anteriormente excluída:

"Europeans; Brazilians, that is, White persons born in Brazil; mullatos, that is, the mixed cast between the Whites and Blacks, and all the varieties into which it can branch; mamalucos, that is, the mixed cast between the whites and Indians, and all its varieties; Indians in a domesticated state, who are called generally Caboclos; and those who still remain in a savage state, and are called generally Tapuyas; negroes born in Brazil, and manumitted Africans; lastly, Mestizos, that is, the mixed cast between the Indians and negroes.",287

\footnotetext{
${ }^{286}$ Ibidem, p. 475.

287 Ibidem, p. 386-387. "Europeus; brasileiros, isto é, a raça mestiça de brancos e pretos, e todas as variedades que podem nascer desse ramo; mamelucos, isto é, mestiços de brancos e indígenas, com todas as suas variantes, indígenas em estado de domesticidade, que são chamados geralmente 'caboclos', e os que ainda se conservam na vida selvagem, e que são comumente denominados 'Tapuias'; negros nascidos no Brasil e os Africanos alforriados, finalmente os Mestizos, casta de indígenas e negros."
} 
A mistura de brancos e pretos na classificação da população livre do Brasil empregado pelo autor confere ambiguidades ao vocábulo "brasileiro", na medida em que as duas divisões de homens brancos feita por ele, distinguiam-se apenas "portugueses" e "brasileiros" de origem europeia.

Ainda que ambiguidades estejam presentes na análise de Koster ao tratar de questões raciais, a definição do que era ser "brasileiro" indica a configuração de uma possível identidade brasileira, referida aos homens brancos:

"The Brazilian, White man of large property, who draws his descent from the first Donatary of a province, or whose Family has for some generations enjoyed distinctions, entertains a high opinion of his own importance, which may sometimes appear ridiculous; but which much oftener leads him to acts of generosity, - to the adoption of liberal ideas, - to honorable conducts. If he has been well educated, and has had the good fortune to have been instructed by priest whose ideas are enlightened, who gives a proper latitude for difference of opinion, who tolerates as he is tolerated, than the character of a young Brazilian exhibits much to admire. Surrounded by numerous relatives, and by his immediate dependents, living in a vast and halfcivilized country, he is endued with much independence of language and behavior, which are softened by the subordination which has been imbibed during his course of education. That this general, I pretend not to say; few persons are instructed in a proper manner, and again, few are those who profit by the education which they have received; but more numerous are the individuals who now undergo necessary tuition, for powerful motives have arisen to urge the attainment of knowledge." 288

\footnotetext{
${ }^{288}$ Ibidem, p. 388 "O Brasileiro, homem branco, grande proprietário, descendente dos primitivos Donatários do país, ou de família que haja gozado distinções, mantém uma alta ideia de sua própria importância, a ponto de tornar-se ridículo algumas vezes, mas frequentemente o conduz ao cimos da generosidade, adotando pensamentos liberais e conduta honrada. Se ele foi bem educado, e teve a felicidade de ser instruído por um padre cuja ideias fossem esclarecidas, sendo compreensivo para a diversidade de opiniões, tolerando o tolerável, no caráter desse brasileiro terá muito o que admirar-se. Cercados por numerosos parentes e dependentes imediatos, vivendo em um vasto e semicivilizado país, ele se habituou a ter muita independência de linguagem e de atitude, moderada pela subordinação ao que aprendeu durante o período de sua educação. Não pretendo dizer que esse seja o tipo geral. Poucas pessoas são instruídas de maneiras convenientes, e ainda mais, poucos são fieis à educação recebida, mas são numerosos os indivíduos que seguem uma orientação necessária, desde que poderoso motivos positivaram a urgência das vantagens da instrução."
} 
Aqui percebemos indicações do que é ser "brasileiro", pautada pela conduta moral e pela configuração familiar, fundamentada em grande medida pelo local descrito na narrativa, onde residiu no período em que aqui esteve, não conhecendo outro tipo societário dentro da organização social do Brasil, caracterizada por suas feições multifacetadas. A construção de uma imagem acerca dos habitantes do Brasil por meio de uma definição do que seria "brasileiro" compreende, ademais, a questão do nível de conhecimento que, a partir de diversas perspectivas, constituí mais um dos lugarescomuns das narrativas de viagem.

Na obra de John Luccock há uma diferenciação nas denominações dadas aos termos "brasileiro" e "português", com relação às características que têm origem em aspectos políticos da colônia. Particularmente dada às intrigas, segundo o viajante, a gente do Brasil manteria propensão grande em agravar este traço devido ao sistema da política colonial, paixão predileta que, segundo ele, ganhou novo campo para exercício e desenvolvimento desde a chegada da Corte:

"Few as were the honors and emoluments which the Prince had to bestow, all sought them with eagerness, all endeavored to supplant each other in the good grace of the in power. Hence jealousies arose, and, between the old Courtiers and the new, got to high degree of virulence; hence frequent bickering and open dissentions, until the parties gradually divided into Lisbonian and Brazilians.",289

No contexto de vinda da Corte ao Brasil, o viajante refere-se aos luso americanos como "novos cortesãos" e aos portugueses de Portugal, "velhos cortesãos". Novos, porque a vinda do Príncipe Regente propalou uma vida cortesã antes nunca conhecida no Brasil, não tendo a população no cotidiano, até este momento, a simbologia que a presença da realeza procriava. No plano político, no qual a posição que se assumia na colônia era compatível com o papel de complementariedade à Metrópole, a elite portuguesa da porção colonial do Império alavancava posições sociais a partir da

\footnotetext{
${ }^{289}$ J. Luccock. Notes on Rio de Janeiro..., cit. p. 94. "Escassos, como eram, as honras e os emolumentos que o Príncipe se achava em condições de outorgar, todos os disputavam com ardor, esforçando-se todos por suplantarem-se uns aos outros na conquista das boas graças dos poderosos. Daí nasceram invejas que, entre os velhos cortesãos e os novos, atingiram alto grau de virulência ; daí surgirem alterações e dissensões abertas que afinal resultaram em gradualmente dividir os partidos em lisboetas e brasileiros."
} 
diferenciação com os demais habitantes e proximidade com o português da Europa ${ }^{290}$; o impacto causado no ordenamento deste equilíbrio entre as partes do Estado português com a vinda da Família Real produziu mudanças imprevisíveis, encerrando uma modalidade secular de dominação: a América passa a ser liberada do exclusivo colonial $^{291}$. Assim, tanto na esfera simbólica - que para a elite luso americana, tendo nas mercês a ferramenta de elevação social, significava mais que presenciar festejos e cortejos públicos, quanto na política - que reordenou as relações entre os súditos europeus e americanos, foram gradualmente agudizando as fissuras entre "lisboetas" e "brasileiros".

A situação de indigência em que a Corte teria desembarcado no Brasil e as heranças de caráter dos primeiros portugueses que se estabeleceram no país, mencionadas acima, também edificam o discurso do viajante com relação às distinções dos vocábulos referentes aos habitantes. Ao passo que os "ricos brasileiros" tinham casas e outros bens, que poderiam ser colocados de lado em favor da Corte migrada, esta estava destituída de bens materiais e dependente da boa vontade dos daqui. Assim, os habitantes do Brasil com algum pertences de valor tornaram-se, segundo ele, visitas bem-vindas na Corte, não só pela amizade supostamente a ser conquistada, mas principalmente por serem feitas retribuições superficiais a eles em troca de benefícios muito maiores para os portugueses recém-chegados. Luccock observava que, na verdade, o governo não havia deixado a cargo dos daqui escolher entre dar ou recusar casas e outros bens materiais; os que gozavam de pouca influência na Corte mal puderam, segundo ele, manter sequer uma casa em suas posses e que, extensiva a ordenação à armazéns e lojas, tiveram que entregá-los não somente aos necessitados "emigrant from the mother country", mas também a comerciantes aventureiros de toda parte. $^{292}$

A distinção está fundada entre os portugueses da Europa que residiam ou passaram a residir no Brasil no início do século XIX, e os descendentes do que o

\footnotetext{
${ }^{290}$ I. Jancsó\& J. P. G. Pimenta. Peças de um mosaico..., cit. p. 402.

291 Ibidem, p. 411 e 417. O dito "jogo de perde e ganha" que envolveu as regiões e setores da elite americana neste contexto, apontado pelos autores, coloca em evidência a nova situação que ampliou a percepção das elites referentes à gestão da coisa pública devido à proximidade com o centro de poder. Assim, "o tradicional equilíbrio político entre as capitanias ou, mais exatamente, entre os grandes centros de convergência do espaço luso-americano, cada qual ligado a Lisboa onde se realizava a unidade do todo por eles formado, foi bruscamente substituído por outro que instaurava uma hierarquia entre espaços sociais que anteriormente relacionavam-se horizontalmente [...].”

${ }^{292}$ J. Luccock. Notes on Rio de Janeiro..., cit. p. 99.
} 
viajante chama de "early Brazilians". ${ }^{293}$ Indicativo desta diferença podemos observar na afirmação de que os habitantes nativos de Santa Catarina, primeira parada de muitos dos colonizadores primitivos, diferiam consideravelmente, ao que ele notava, dos verdadeiros "bred Potuguese", por traços físicos e de maneiras, diversidade estas talvez em decorrência, segundo ele, da quantidade de estrangeiros que por lá passavam em visita. ${ }^{294}$ Os primeiros colonizadores, ao longo do tempo e por causa das misturas a que estaria submetido um local de grande fluxo de pessoas, segundo o autor, ao perderem suas características físicas de origem, diferenciavam-se dos portugueses que se estabeleceram no Brasil a partir de 1808. É como se ao longo da colonização portuguesa no Brasil, o português europeu que se estabeleceu no país, e seus descendentes, angariassem feições e maneiras que fizessem dele não mais o português de origem, mas um exemplar de português com características que o situaria dentro de um grupo humano diferenciado, mais próximo do "brasileiro".

Luccock chama a atenção para a diversidade de moldes que construiria o caráter do "brasileiro": as degradações de ideias e maneiras observadas nos habitantes do Brasil eram comuns, segundo ele, a todo "brasileiro", que pensava e agia de maneiras diversas das que os europeus agiriam se colocados em semelhantes circunstâncias. ${ }^{295}$ Posição recorrente nos relatos dos viajantes oitocentistas, a de estampar em suas páginas os meios e atitudes pretensamente mais evoluídas exclusivamente por serem oriundos de nações ditas civilizadas, exemplo a ser seguido pelas sociedades ainda no germe do progresso, como era o Brasil na visão destes indivíduos. Analisando a população do Rio, Lucocck constatou que era fácil admitir que houvessem homens honrados e de bons princípios em meio à população, ao mesmo tempo em que era impiedoso negar existirem ali misturas de boas e más qualidades, como de fato acontecia em toda parte no mundo. Mas no Brasil, em muitos destes caracteres, segundo ele, havia uma predomínio incomum do mal, constituindo uma parcela corrompida muito maior a comum geralmente observada em outros lugares. Esta constatação não foi acompanhada, segundo ele, por nenhuma "qualidade nacional" de natureza sólida. O viajante não isentou nenhuma classe dos hábitos famigerados que observou, relatando em seu texto:

\footnotetext{
${ }^{293}$ Ibidem,p. 456. "brasileiros primitivos".

${ }^{294}$ Ibidem,p. 240."portugueses de origem".

${ }^{295}$ Ibidem, p. 420.
} 
"Not negroes and the populance alone contemplated them with apathy; the moral taste and feeling of persons of a higher cast partook so much of the common taint that, when we mentioned with horror, the worst of crimes, which we were obliged to witness, they often advanced something by way of defense, and really appeared as much surprised at our mode of thinking as if we had broached a new religion, or foisted into the old one some scrupulous fancies. ${ }^{296}$

O meio no qual a sociedade colonial estava inserida, apartada até o momento e até certo ponto da vinda destes forasteiros e do centro europeu que, ademais, constituía o parâmetro de análise do estado de evolução de uma sociedade, aos olhos dos estrangeiros, constituía entrave à inserção de práticas que para os "brasileiros" não condiziam com a realidade vivida, fosse para os menos abastados que nunca deixaram o Brasil, fosse para as classes mais altas que não escaparam à crítica do viajante.

A diversidade diante do "outro", tanto para o estrangeiro quanto para o habitante, compunha as reações de ambas as partes perante situações do cotidiano, levando o primeiro a um sentimento de aborrecimento com relação ao segundo, ao passo que o segundo, mesmo na presença de atitudes diferentes da sua, enxergava no primeiro um tipo humano a ser "invejado" e copiado, que na visão eurocêntrica de superioridade do europeu diante do americano, quase sempre resultava em situações ou modos "fora de lugar". Exemplo desta contradição do ingresso de maneiras estrangeiras entre os habitantes do Brasil está na primeira visita que Luccock fez ao Rio de Janeiro, em 1808, antes dos melhoramentos que a presença da Corte causaria nos habitantes. Nesta ocasião, comentava que os estrangeiros faziam o que estava ao seu alcance para acompanhar os gostos e maneiras dos residentes, mas que pouco a pouco, sendo as visitas mais frequentes, os modos e usos dos visitantes foram sendo introduzidos:

"I have never dined in a Brazilian house, where part of the furniture of the table was not English, particularly the earthenware and glass. Before such luxuries were introduced, they had pewter plate, or a rough sort of Dutch

\footnotetext{
${ }^{296}$ Ibidem, p. 135. "Não são somente os pretos e a populança que os comtemplam com apatia; o senso moral das pessoas de melhor casta de tal modo partilha da nódoa comum que, quando citávamos horrorizados os piores crimes a que éramos obrigados a assistir, frequentemente tentavam dizer algo em defesa deles e, na realidade, pareciam tão surpreendidos com a nossa maneira de pensar, como se tivéssemos inventado uma religião nova, ou introduzido na velha alguns escrúpulos fantasiosos.”
} 
pottery, with some smalls Portuguese tumblers, narrow at the bottoms and the mouths wide [...] Occasionally, individual made a profuse display of plates and jewels.",297

O caráter das observações estabelecidas na narrativa está pautado pela ótica de padrão civilizacional, tanto no sentido dado pelo viajante aos costumes e modos britânicos, quanto no de deformação de situações sociais na medida em que os da terra tentavam acompanhar os hábitos dos estrangeiros. Não raro o fato das pessoas de posse adotar maneiras estrangeiras, a fortuna dos "brasileiros" que podiam ostentar mudança aparente nos hábitos, fosse à forma de conduzir um jantar ou de se vestir e portar diante dos outros, não os levava a conhecer os modos de usar as novas maneiras de forma graciosa, na opinião de Luccock. Os "brasileiros", segundo ele, pouco acostumados a cortejar, receber, se vestir bem, etc., com frequência representavam cenas de selvageria, nas quais as boas intenções não se mostravam o suficiente para se bem portar em sociedade. $^{298}$

De acordo com esta ótica, o "brasileiro" é vislumbrado a partir do "outro": os elementos de análise que dão sentido ao discurso dos viajantes estão fundamentados numa postura de superioridade do estrangeiro com relação ao luso americano, estabelecendo comparações que, ademais, refletem o campo da versão. Em começos do século XIX o Brasil constituía uma sociedade de tipo escravista que apresentava contrastes fundamentais para os viajantes pensarem os habitantes da terra da forma como foram pensados, resultando em opiniões sobre eles que acabou por sintetizar características diferenciadoras de outras sociedades, principalmente a de origem do viajante. ${ }^{299}$

\footnotetext{
${ }^{297}$ Ibidem, p. 123. "Nunca jantei em casa brasileira que parte dos objetos de mesa não fosse ingleses, especialmente a louça e a cristaleira. Antes de tais luxos terem sido introduzidos, usavam de pratos estranhos ou de uma espécie de cerâmica holandesa, com uns pequeninos copos portugueses sem pé, estreitos no fundo e com a boca larga [...] Por vezes, havia pessoas que faziam grande exibição de metais preciosos e joias".

${ }^{298}$ Ibidem, p. 124.

${ }^{299}$ Maria Sylvia de Carvalho Franco analisa o homem livre e pobre nas relações de dominação que se desdobram das estruturas socioeconômicas do Brasil do século XIX. Homens livres na ordem escravocrata. São Paulo: UNESP, 1983. Uma abordagem clássica sobre as relações raciais no Brasil podem ser vistas em Caio Prado Jr.. "Vida Social e Política". In: Formação do Brasil Contemporâneo: Colônia. $19^{a}$ edição. São Paulo, Brasiliense, 1986, pp. 341-377.; F. Florestan. "A sociedade escravista no Brasil”. In: Circuito Fechado. São Paulo, Globo, 2010, pp. 33-95.
} 
Para além de descrições específicas sobre os modos dos habitantes do Brasil, o trecho a seguir, de certa forma, condensa os traços dos descendentes dos primeiros colonos, a quem o viajante distingue dos "portugueses":

"Having described myself as an English Merchant, my host took a bunch of keys, opened a small store at the other end of his premises, and invited me to remove to it $[\ldots]$ He was manifestly vain of his goods, and wished to show that he also was a merchant $[\ldots]$ In his person this man was very broad and heavy, loaded with fat, and moved with listlessness, he was in every respect a true bred county Brazilian, and his countenance possessed the peculiar features of that class of people. Their most obvious peculiarity is in the eyes, which are large, prominent, and distorted; the iris being exceedingly dark, while the cornea possesses a dazzling brightness and displays itself between eyelids unnaturally expanded. The man seems to look over both shoulders at once, seldom, when unroused, places his eyes directly upon anything, nor keeps them long in one position. Such countenances, it is obvious, to a stranger unfamiliarized with them, express the extreme of savage ferocity. This distortion has been acquired at first, I think, by the constant alarm in which the early settlers lived, and by the usual process of nature has been communicated from father to son, when the circumstances which produced it have ceased to exist." ${ }^{, 300}$

Novamente, o olhar específico de Luccock sobre os habitantes adere traços que para ele são constituintes do "true bred country Brazilian". 301 Ao mesmo tempo em que

\footnotetext{
${ }^{300}$ Ibidem, p.391-392. "Tendo-me apresentado como sendo negociante inglês [em Pampulha], o vendeiro sacou de um molho de chaves, abriu um pequeno depósito na outra extremidade e suas dependências e convidou-me a que me transportasse para lá [...] Estava ele manifestadamente vaidoso de suas mercadorias, desejando mostrar que também ele era negociante [...] Quanto a sua pessoa, esse era homem volumoso e pesado, carregado de banha, movendo-se com descuido e, por todos os seus aspectos, um legitimo produto nacional do Brasil, possuindo toda a sua fisionomia o feitio peculiar dessa casta de gente. A mais gritante dessas peculiaridades reside em seus olhos que são sempre grandes, proeminentes e tortos, sendo a íris extraordinariamente escuras, enquanto que a córnea possui deslumbrante brilho, revolvendo dentro de pálpebras desmesuradamente abertas. O sujeito parece olhar simultaneamente por cima de ambos os ombros; é raro que, estando sua atenção despertada, conserve seu olhar diretamente sobre o que quer que seja, como tão pouco os conserva por muito tempo no mesmo alvo. Tais maneiras, é claro, a um estranho que a elas se não tenha familiarizado, dão a impressão da mais extrema ferocidade. A origem desses olhos torcidos creio estar no alarme perpétuo em que os primeiros colonos viviam, e, por processo usual da natureza, transmitiu-se mais tarde de pais a filhos, mesmo depois que as circunstâncias que produziram o fenômeno já tinham cessado de existir."

${ }^{301}$ Na edição de 1942, traduzido como "legítimo produto nacional do Brasil".
} 
a desconexão das províncias fosse aspecto sublinhado por muitos viajantes, no que se refere ao caráter humano, uma descrição específica faz referência de modo geral a todos os habitantes. Os traços "nacionais" que o autor analisa no Brasil estão condicionados à classe social da qual ele obteve mais informações, justamente por ser o tipo de gente no meio da qual ele mais esteve presente durante sua estadia no país. Ao que tudo indica, a ordenação das análises feita nas narrativas sobre os habitantes do Brasil emerge de elementos conhecidos da rotina dos viajantes, do seu ofício, dos ambientes mais frequentados por eles, etc.

Neste sentido, Luccock mostrou mais propensão que os demais viajantes analisados a distinguir os habitantes da América portuguesa entre os indivíduos que de alguma forma relacionavam-se com sua própria profissão. Diferentemente de Koster, que viveu numa região do país onde imaginava a vida estranha que levava, relacionando à época feudal na Europa, comparável ao estado em que se encontrava o "interior do Brasil”,302, Luccock estava inserido num ambiente urbano, onde estabelecia relações comerciais, motivo principal de sua estadia no Brasil.

A época em que cada um destes agentes históricos esteve no Brasil também constitui influência nos vocábulos utilizados para se referirem aos habitantes. Ao passo que os viajantes analisados até aqui fazem uso do termo "brasileiro", uns menos outros mais, Maria Graham, além desta terminologia totalizadora a que todos empregam nas análises, faz muito uso do termo "patriota", que não foi utilizado pelos outros britânicos aqui analisados, mas que, nela, tem uso frequente. Enquanto Mawe, Koster, Luccock, e mesmo O’Neil, que pouco escreveu sobre os habitantes da América portuguesa, concentrando-se mais nos acontecimentos que sucederam à partida da Família Real de Lisboa, utilizaram "portugueses", "brasileiros" e suas variáveis como elementos de análise dos indivíduos observados aqui, Graham, escrevendo sobre o Brasil também após a proclamação da independência, não dispensa tais vocábulos, mas diferencia-se daqueles pelo uso de expressão que refletia o momento político do Brasil.

Neste momento, além da disposição para a revolução, estando prevenida da existência de tensões em todas as partes do Brasil, "there was, also, a jealousy between the Portuguese and Brazilians, which recentes events had increased in no small degree". ${ }^{303}$ A 23 de setembro de 1821, a tripulação ancorada em Pernambuco,

\footnotetext{
${ }^{302}$ Ibidem., p. 224.

${ }^{303}$ M. Graham. Journal to a voyage..., cit. p. 97 "havia também rivalidade entre portugueses e brasileiros, situação que os últimos acontecimentos haviam agravado em não pequeno grau."
} 
“About three o'clock a large canoe with two patriot officers come alone side, to ascertain if we were really English, if we had come as was reported, to assist the royalist, or if we would assist them: so apt are men, under the influence of strong feeling themselves, to doubt of perfect indifference in others, that I question much whether they believe in the strict neutrality we profess." 304

Ao passo que as diferenças entre os que passaram a ser considerados "portugueses" ou "brasileiros" se agudizavam com os acontecimentos políticos vividos pelo Império português, desestabilizando o equilíbrio entre ambos, o movimento revolucionário permitiu a ampliação e politização do uso de expressões como "patriotas" e "realistas" que faziam sentido para a viajante se referir àqueles que de modo mais visível fariam parte de um ou outro grupo.

Com relação às populações nativas do Brasil, Graham observa que as terras concedidas a Portugal tiveram que ser conquistada entre selvagens que se sucediam em inumeráveis multidões, de hábitos migratórios, o que tornava a conquista mais dificultosa por ser natural a uma tribo ocupar o terreno de onde uma outra havia sido expulsa. Não existia nelas a "remembrance of national honour and freedom" que, segundo a autora, permaneceu viva entre os mexicanos e peruanos, o que teria acelerado a libertação destes povos. ${ }^{305}$ Ao mesmo tempo, as terras conquistadas por Portugal não mais seriam recuperadas pelos indígenas, justamente porque careciam de tradição e de esperança de uma era melhor, sendo os "selvagens" exterminados ou subjugados totalmente. Segundo a viajante, só as rivalidades entre os próprios portugueses poderiam conduzir aos acontecimentos dos quais estava sendo testemunha. ${ }^{306}$ Enquanto na América espanhola, segundo a autora, os primitivos, ao lado dos "crioulos"307, constituíam parcela real dos pregadores da independência, os índios no Brasil nada representavam. Ou seja, a rivalidade que Graham aponta entre "brasileiros" e

\footnotetext{
${ }^{304}$ Ibidem, p. 99."Cerca de três horas um grande barco, com dois oficiais patriotas, aproximou-se, para certificar-se de que éramos realmente ingleses, e se tínhamos vindo, como se dizia, para ajudar os realistas, ou se ajudaríamos a eles. Os homens, debaixo da influência de fortes sentimentos, são tão capazes de duvidar da perfeita indiferença da parte dos outros, que eu duvido muito tenham eles crido na estrita neutralidade que professamos."

${ }^{305}$ Ibidem, cit., p. 2.

${ }^{306}$ Ibidem, p. 3.

${ }^{307}$ Expressão empregada com sentido de "espanhol nascido na América".
} 
"portugueses" não teria tido contribuição de outra classe de gente que não deles próprios.

Para a viajante, as rivalidades teriam sido desencadeadas com a vinda da Família Real, embora não tenham derivado somente deste fato, mas incentivadas pela chegada da "new people of Brazil"308. Na medida em que a autora atribui às sociedades indígenas encontradas na porção espanhola da América características que permitiam associação destas a um sentimento nacional, termo utilizado no sentido de apego a referenciais de formas de vida - tais como cultivo da terra e organização social - o sentimento de pertencimento entre os portugueses, unidos outrora no mesmo projeto de dominação e colonização do Brasil, não foi capaz de superar divergências que o tempo causou nos grupos separados entre Metrópole e Colônia, no momento de crise vivido por Portugal. No momento da história do império português em que a colonização das terras americanas configurava objetivo comum tanto para os portugueses da Europa quanto para os colonizadores estabelecidos no Brasil, a autora une ambos num mesmo grupo de pertencimento, o dos "portugueses".

Já a partir da instalação da Corte portuguesa no Brasil, os distanciamentos entre "brasileiros" e "portugueses" foram observados por Graham pela ótica da política. No entanto, ao mesmo tempo causadora de rivalidades, as ocasiões políticas desencadeadas na visão da viajante pela chegada da Corte teriam resultado na "union of the two nations", e, de certo modo, direcionou suas anotações na direção de observações que fizessem referência tanto aos "European Portuguese", quanto aos "born Brazilians", "creole portuguese", 309 todas expressões utilizadas por ela. Ainda que a conjuntura política do momento descrito no diário de viagem permita a constatação de outros critérios do que poderia ser "português" ou "brasileiro" além do local de nascimento, em Graham as diferenciações com relação à origem de um e outro grupo é notável:

"The European Portuguese are extremely anxious to avoid intermarriage with born Brazilians, and prefer giving their daughters as fortunes to

\footnotetext{
${ }^{308}$ Ibidem, p. 50. "Nova gente do Brasil".

309 "a união de duas nações", "portugueses europeus", "nativos do Brasil", "portugueses nativos da terra", traduções dadas na edição de 1956.
} 
meanest clerk of European birth, rather than to the richest and meritorious Brazilian." 310

Abordando, portanto, as questões políticas do conturbado período em que esteve no Brasil, Graham possuía referenciais identitários tão complexos quanto diversos, semelhantemente aos demais viajantes analisados, mas que foram aplicados aos habitantes do Brasil em momentos diferentes da agitada primeira metade do século XIX. O termo "brasileiro" para Koster ou Luccock, por exemplo, tinha configuração mais bem elaborada dentro das demais expressões identitárias utilizadas, não obstantes algumas incongruências. Em Graham, os acontecimentos oriundo da história de Brasil e Portugal dão inteligibilidade aos sentidos conferidos a "portugueses" e "brasileiros": enquanto as liberdades e os bônus oriundos da colonização do Brasil estavam equilibrados entre os portugueses do Brasil e os portugueses de Portugal, os dois grupos estão unidos pela autora no termo "português"; em contrapartida, com o passar do tempo, as diferenças entre os dois grupos foram supostamente aprofundando-se e teriam eclodido com mais suntuosidade com a presença do Príncipe Regente no Brasil e, a partir daí, ganhado variáveis que iam além do local de nascimento, culminando na adesão ao movimento de independência.

Da análise de todos esses viajantes britânicos que percorreram o Brasil na primeira metade do século XIX, a diversidade de sentidos conferidos ao termo "brasileiro" e o interesse que eles demostravam a respeito deste homem são indicativos da importância dada à identidade na configuração de uma nação, ainda que em germe, que estava sendo constituída. Os europeus, em especial os britânicos devido à influência econômica sobre o Brasil e como consequência a dominação de uma cultura por outra, estariam à frente no caminho rumo à civilização, estando dispostos nos relatos como o exemplo a ser seguido no processo de formação de uma sociedade refletida nos seus hábitos e costumes. Decorrentes disto, os vocábulos que esses viajantes empreenderam em seus textos mostraram-se variados e estabeleceram relação com os tipos que encontraram ao longo da viagem e, em especial, com o momento em que escreveram sobre a gente do Brasil.

\footnotetext{
${ }^{310}$ Ibidem, p. 126. "Os portugueses europeus ficam extremamente ansiosos por evitar o casamento com os naturais do Brasil e preferem antes dar suas filhas e fortunas ao mais humilde caixeiro de nascimento europeu do que aos mais ricos e meritórios brasileiros."
} 


\section{Os franceses e os "brasileiros"}

Enquanto concorrente direta dos britânicos na corrida por poder em um dos lugares mais visados no início do século XIX, a presença francesa no Brasil não só era mais antiga, intensa e persistente que a inglesa, holandesa e norte-americana, como funcionou como irradiador de uma revolução bibliográfica que forneceu instrumental conceitual em momentos de crise. ${ }^{311}$ Já com relação à presença econômica dos franceses no Brasil, a dura concorrência com o processo de acumulação de capitais industriais que a Inglaterra transferia para a comercialização causavam aos franceses grandes dificuldades. ${ }^{312}$ Não obstante estes fatos, a França estava entre as potências europeias em crescente industrialização e definição de uma burguesia que demandava cada vez mais mudanças no cenário francês. ${ }^{313} \mathrm{E}$ as tentativas de expansão dos mercados franceses no Brasil eram acompanhadas pela influência cultural marcante na elite luso americana que dispunha dos modelos de conduta nos modos de vestir, comer, se portar em público, além da inserção de artistas franceses que teriam tido o papel de inserir o Brasil no gosto e moldes europeus.

Denis orgulhosamente notava que, como parte do processo de evolução de uma população com a ajuda de outra mais evoluída, competia aos franceses reivindicar a anterioridade de iniciação nas artes e nas ciências na história do desenvolvimento social do Brasil, ainda que os ingleses tivessem sido os primeiros a desenvolver as atividades comerciais entre os "brasileiros", secundadas pelos franceses mais trade. ${ }^{314}$ Assim, os viajantes franceses, que também vieram ao Brasil com propósitos diversificados, esboçaram o "brasileiro" com vistas a diagnosticá-lo dentro do processo de formação de uma nação no caminho da civilização.

Com objetivos comerciais explicitados em seu relato, L. F. Tollenare veio ao Brasil em 1816 em busca de novos fornecedores de algodão, negócio afetado substancialmente pelas guerras napoleônicas. Sua disposição para a viagem influenciou em grande medida as observações sobre a vida no Brasil e as descrições sobre seus habitantes. Segundo o viajante, o estado de vigor em que encontrou Pernambuco foi em parte favorecido pela cultura do algodão - enquanto o crescente progresso verificado na

\footnotetext{
${ }^{311}$ C. G. Mota. Presença francesa em Recife em 1817. Cahiers du monde hispanique et luso-brésilien, $\mathrm{n}^{\circ} 5$, 1970, Brésil, p. 49.

${ }^{312}$ Ibidem, 51-52.

${ }^{313}$ Algumas contribuições sobre a presença francesa no Brasil em: Laurent Vidal \& Tania Regina de Luca (orgs.). Franceses no Brasil. Séculos XIX-XX. São Paulo: Editora UNESP, 2009.

${ }^{314}$ F. Denis. Brasil..., cit. p. 3.
} 
cultura do açúcar no século XVIII estava comprometido desde que esta produção entrou em concorrência com o das Antilhas ${ }^{315}$ - e, principalmente, o de elevado grau de prosperidade devido à transferência da corte ao Brasil e a abertura dos portos a todas as nações. ${ }^{316}$ Observava que era deste ponto de vista que iria empreender suas observações e que falando da capitania e dos "brasileiros", não teria intenções de tratar senão da cultura e do comércio com os europeus: "mes Brésiliens ne seront que lês descendants plus ou moins directs, plus ou moins mêlés, des Européens", não se ocuparia nem de desertos, nem de monstros selvagens, nem de antropófagos; entre eles e a sua pessoa havia uma grande zona em que se falava o português, e era provável que não a transporia" ${ }^{317}$ Notamos que a intencionalidade do comerciante em tratar estritamente de assuntos que lhe eram de domínio, a extensão dada a quem são os "brasileiros" permeia os limites das relações que estabeleceria a partir dos negócios e dos tipos humanos que encontraria em sua estadia no Brasil.

Não sendo naturalista, agrônomo, político ou pintor, segundo ele, caberia aos indivíduos como Humboldts lançar olhares sobre as grandes massas. ${ }^{318}$ Porquanto, as tentativas de apreciar a população mostraram-se infrutíferas ao viajante, segundo ele pela ausência de luzes que ela demonstrava. Ao se deparar com quantidade pequena de indivíduos, objetivou a análise sobre os habitantes pela qualidade deles, estruturando a sociedade da região do atual nordeste do Brasil a partir das relações de produção entre os senhores de engenho, os lavradores, os moradores e os escravos.

Ao senhor de engenho, grande proprietário territorial, que visitava suas dependências munido de chicote, Tollenare atribuiu a qualidade de uma espécie de rei que tinha em volta de si apenas animais, seus escravos negros, a quem maltratava e que eram seus moradores, além de alguns lavradores, denominados por ele de "vassalos inimigos". ${ }^{319}$ A falta de comunicações entre os engenhos contribuiria para o isolamento dos senhores, que mantinham um estilo de vida que os tornava absolutos nos modos de

\footnotetext{
${ }^{315}$ Mota observa que a Europa não carecia somente de cana-de-açúcar, mas sobretudo de algodão e que o "Brasil fornecia os dois produtos essenciais, em abundância e em preços vantajosos." Foi nessa conjuntura, segundo o autor, que Tollenare foi enviado ao Brasil por um primo - operante numa ilha da Flórida em contrabando legal - para comprar algodão para algumas indústrias francesas. C. G. Mota Presença francesa em Recife..., cit. p. 53.

${ }^{316}$ L. F. de Tollenare. Notes dominicales..., cit. p. 37.

${ }^{317}$ Ibidem, p. 342. "Os meus brasileiros são os descendentes mais ou menos diretos, mais ou menos misturados dos europeus; não me ocuparei nem de desertos, nem de monstros selvagens, nem de antropófagos; entre eles e a minha pessoa medeia uma imensa zona em que se fala o português, e é provável que não o transporei."

${ }^{318}$ Ibidem, p. 405.

${ }^{319}$ Ibidem, p.406.
} 
se comportar diante das demais classes aludidas. Exemplo deste comportamento estava numa visita inopinada à casa de um desses senhores, onde pediu um copo d'água na tentativa de passar para outro cômodo, fazendo-o, ao contrário, esperar por muito tempo, dentro do qual não viu nenhuma senhora. $\mathrm{O}$ mesmo havia sucedido em outra casa pertencente a uma portuguesa. ${ }^{320}$

A consideração de que não esteve no "país das luzes" também teve reflexos na observação de Tollenare sobre o comportamento dos "bresiliens" na presença de franceses. A este fato, aconselhava aos homens instruídos a não desdenhar de certo pedantismo caso quisessem disseminar as luzes pelo país, mesmo estando os habitantes propensos a se interessar pelos conhecimentos que um francês poderia ter. Isto porque, segundo ele, a partir do momento em que o estrangeiro demonstrasse não ser químico ou engenheiro, ou que estivesse disposto a discutir apenas o que parecesse acessível ao bom senso, toda a consideração demonstrada pelos "brasileiros" para com os estrangeiros desapareceria num instante, não gostando aqueles de discutir com as luzes naturais que estes poderiam oferecer. ${ }^{321}$

Os lavradores, ao contrário dos senhores de engenho que eram os únicos proprietários de terras, constituíam uma espécie de rendeiros sem escrituras de arrendamento, que plantavam cana, mas não tinham engenho, e que enviavam metade da produção ao senhor de quem dependiam. Esta classe mostrava-se digna de interesse, segundo Tollenare, por possuir algum capital e por trabalhar, opinião condizente com a orientação intelectual e profissional do viajante. De dois a três lavradores por engenho, eram estes “Brésiliens d'origine blanch, peu mélangés de mulâtres", que investiam seu capital em escravos e gado. ${ }^{322}$ Diferentemente dos senhores de engenho, de acordo com o viajante, os lavradores mostravam-se bastante altivos para receber de igual para igual o estrangeiro e as senhoras não desapareciam na sua presença, colocando-os numa posição intermediária entre o "orgulhoso senhor de engenho" e o "humilde morador, preguiçoso e servil". ${ }^{323}$ Diante das características que o autor impõe à classe dos lavradores, ele se deparou com a convicção de que eles teriam participado dos benefícios trazidos pela emancipação comercial do Brasil, introduzindo-os à classe capitalista, e que se fossem agraciados com o favorecimento do governo, assim como os

\footnotetext{
${ }^{320}$ Ibidem, p.407.

${ }^{321}$ Ibidem, p.409.

${ }^{322}$ Ibidem, p. 411. "brasileiros, de origem branca, poucos mesclados de mulatos";

${ }^{323}$ Ibidem, p. 412.
} 
senhores de engenho, estariam destinados a exercer grande papel na economia política do Brasil. ${ }^{324}$

A terceira classe identificada pelo viajante é a dos moradores, que constituía grupo de pequenos colonos aos quais os senhores de engenho concediam permissão para cultivar um pequeno pedaço de terra. Eram em geral mestiços de mulatos, negros livres e índios que moravam em cabanas erguidas no meio do mato. Ao contrário do lavrador, Tollenare afirmava ser uma classe livre paupérrima porque recusava o trabalho, vivendo na ociosidade. Segundo ele, era a que constituía naquele momento "leveritable peuple (plébe) brésilien" que substituiu os "sauvages brésiliens" e valiam menos do que eles “qu'eux, car ceux-ci connaissaient au moins um lien politique et national", enquanto os moradores só se identificavam com os seus cercados, vivendo isolados de toda autoridade civil ou religiosa e consideravam como inimigos todos os que lhes eram estranhos, além de não conhecerem o valor da propriedade. ${ }^{325}$ Compunha, em suma, uma gente preguiçosa, de poucas necessidades, ainda por civilizar.

A divisão geralmente feita com relação à condição econômica dos habitantes não diferencia, ao menos aqui, os indivíduos que poderiam estar inseridos dentro do grupo dos "brasileiros". A classe dos senhores de engenho poderia compreender tanto "brasileiros" quanto "portugueses", não sendo os termos objetivamente identificados no relato para descrever essa porção da população. As outras classes que compunham essa divisão social estão mais bem definidas no texto, na medida em que se expressa claramente a origem dos "bresiliens" nesses grupos. Portanto, em Tollenare, divisões que considerem a origem estritamente branca (descendência europeia), a posição econômica, ou ainda qualquer outra variável geralmente identificada nos relatos de viagem analisados, não são determinantes para ele na classificação dos habitantes da América portuguesa. Esta implica exclusivamente a relação de produção estabelecida entre as classes, identificadas em todas elas a presença de "bresiliens", para Tollenare, mais ou menos misturados dos europeus.

Ao dividir as três classes, não estão consideradas aí os negros cativos, que para o viajante não passavam de gado. ${ }^{326}$ Mas a descrição desse grupo de indivíduos é algo que para um europeu que vinha a um país escravocrata se tornava, de certo modo, "obrigatório". Tollenare percebeu entre eles homens de fisionomia altiva e feroz, ao

\footnotetext{
${ }^{324}$ Ibidem, p. 411.

325 Ibidem, p. 412-413. "verdadeiro povo (plebe) brasileiro"; "selvagens brasileiros"; "porque estes conheciam ao menos um vínculo político nacional"

${ }^{326}$ Ibidem, p. 403.
} 
mesmo tempo em que se viam muitos negros calmos e submissos, chegando à constatação de que, em geral, o aspecto não apresentava prantos, gritos ou desespero. Entretanto, não poderia o estrangeiro que desembarcasse no Brasil se furtar de um sentimento penoso que causava à primeira vista a escravidão. ${ }^{327}$ A constituição de uma sociedade hibrida que tem como um de seus fundamentos o catolicismo, atraía a atenção de um viajante que tinha nos seus referencias de moral a igreja católica, mas que via frades sendo servidos por escravos, e testemunhava espantosamente cristãos mantendo cristãos na escravidão sob autorização das leis canônicas do país. ${ }^{328}$ Ademais, a análise empreendida por Tollenare a respeito dos escravos tem respaldo na classe dos moradores, atribuída aos mestiços de mulatos e negros livres. Estes indivíduos, considerados a parcela da população a qual se poderia projetar o exemplo de indolência e ociosidade, ofereciam às vezes seus serviços nos engenhos como carpinteiros ou pedreiros e os que não possuíam estes ofícios viviam em um estado miserável, sem que tivessem grandes necessidades num clima que oferecia grandes recompensas com o mínimo de trabalho. ${ }^{329}$

Quanto aos negociantes, estes são apontados pelo viajante como maioria composta por pessoas nascidas em Portugal. A caracterização deste grupo está pautada pelo amor ao país de origem e pela "vanité nacionale" que via com pesar Lisboa perder muito de sua prosperidade devido à emancipação comercial do Brasil, fazendo-os acolher com prazer os projetos que visassem fazer voltar à sua pátria os benefícios de que gozavam com exclusividade. Estariam os "négociants portugais du Brésil", portanto, "aux prises entre l'amour de pays et leur prope intérêt", enquanto o próprio governo estaria embaraçado com a situação, sem saber ainda qual medida tomar. ${ }^{330}$ Levemos em consideração que o momento em que Tollenare escreve não estava definido os parâmetros que realocariam de modo mais substancial "portugueses" e "brasileiros" na configuração identitária correspondente aos domínios luso americanos, permitindo tão somente a possibilidade de pertencer a um ou a ambos os grupos.

Podemos observar tal inclinação no que Tollenare escreveu sobre Simplício Dias da Silva, um dos mais opulentos particulares do Brasil que o viajante teve a oportunidade de conhecer: Simplício teria conhecido o devido respeito à civilização

\footnotetext{
${ }^{327}$ Ibidem, p. 317.

${ }^{328}$ Ibidem, p. 333.

${ }^{329}$ Ibidem, p. 362.

${ }^{330}$ Ibidem, p. 455. "vaidade nacional"; "negociantes portugueses do Brasil"; "manietados entre o amor da pátria e o seu próprio interesse, porque quase todos são proprietários no Brasil"
} 
viajando pela França e pela Inglaterra; ocupava-se das belas-artes, vivia com um luxo asiático, mantendo músicos, acolhendo estrangeiros, vivendo nos seus domínios como um homem poderosamente rico, segundo Tollenare. Porém, diante de tantas qualidades somente identificáveis plenamente em um europeu, o viajante apontava que era possível que o senhor Simplício fosse mais "brasileiro" do que "português", mas que isto não era um crime, tendo a corte emancipado o reino do Brasil, sancionando tais afeições. A consideração de que ele poderia ser mais "brasileiro" pode ter relação com a origem mesclada deste proprietário, que era filho de uma mulata, sendo muito variados, segundo Tollenare, os pontos de vista a partir dos quais poderia ser descrito. ${ }^{331}$ Seja como for, era possível permear ambas as identidades sem que isso acarretasse incongruências ou ambiguidades, perspectiva endossada pela descrição.

É a partir do movimento político em Pernambuco do qual foi espectador, que Tollernare afirmava categoricamente: "Beaucoup de gens, et notamment lês troupes, parurent apprendre alors pour la première fois qu'il fallait faire une distinction entre lês Portugais brésiliens et ceux d'Europe". Não se ouviam ainda os gritos de viva à liberdade, mas o de "Viva à Pátria! Mata o Marinheiro!", como os "brasileiros" designavam os portugueses da Europa, de acordo com o viajante, não importando a qual classe pertenciam. ${ }^{332}$ A proclamação da Revolução de 1817 , que à primeira vista só se viu a fraqueza e indignou alguns portugueses, segundo o viajante, fez algo mais, indo além da percepção momentânea do movimento: colocou a questão das identidades em níveis que a presença estrangeira pode pôr em cena.

Independente dos sucessos que a revolução angariasse no futuro, para Tollenare os insurgentes não poderiam se iludir na esperança de que a liberdade de uma gente pudesse ser conquistada por meio do que ele considerou ser de pouca importância, custando a vida de 50 ou 60 pessoas. Para o viajante, a revolução não preparou a população para a liberdade; ao contrário, ela teria assistido muito friamente o embarque do governador derrotado pelos insurgentes, que partiu levando as "melédiction des Européens et les satiriques félicitations des Patriotes", devendo sua vitória à inabilidade e fraqueza de caráter. ${ }^{333}$ De qualquer forma, independente da interpretação que este ou aquele estrangeiro tenha dado a momentos importantes da vida política do Brasil, o

\footnotetext{
${ }^{331}$ Ibidem, p. 515-516. Tollenare afirma não ter tido acesso às altas classes sociais no período em que esteve no Brasil. As observações feitas por ele sobre Simplício Dias da Silva foram com base em descrições de outros estrangeiros.

${ }^{332}$ Ibidem, p. 546-547. "Muita gente, notadamente as tropas, pareceu saber pela primeira vez, que cumpria distinguir entre os portugueses do Brasil e os da Europa".

${ }^{333}$ Ibidem, p. 550. "maldições dos europeus e as felicitações satíricas dos patriotas"
} 
olhar externo que os viajantes puderam aplicar em momentos importantes na configuração e politização das identidades coletivas no Brasil possibilitou ao fenômeno político a oferta de uma identidade específica que ganhava, ao mesmo tempo, legitimação por parte dos estrangeiros que escreviam sobre ela.

Integrante da expedição francesa que ficou conhecida como "Missão Artística de 1816", Jean Baptiste Debret veio ao Brasil, onde permaneceu por 15 anos e ajudou a fundar a Academia de Bela-Artes no Rio de Janeiro. Historiador fiel, como ele próprio se designava, foram reunidos na sua Viagem Pitoresca e Histórica ao Brasil os documentos relativos aos progressos desta expedição. Seus esforços pretendiam reproduzir as "scènes nationales ou familières du peuple",334 entre o qual passou anos de sua vida e, consequentemente, o "brasileiro" foi tema recorrente em sua obra, ao que diz oferecer ao público "description exacte du caractere et des habitudes des Brésiliens en general.",335

A construção da imagem dos indígenas nos relatos de viagem dá ênfase, geralmente, ao primitivismo e ao caráter antropológico do "selvagem", o que de certa forma aparta estes indivíduos de uma análise mais sistemática da formação identitária composta pelos indivíduos definidos no termo "brasileiro". Na medida em que a abordagem da natureza dentro do esquema de representação preexistente à viagem produzia as alteridades que alocariam o europeu no sistema de conceitos e imagens civilizatórias, pertinentes aos viajantes do século XIX com relação ao Brasil, Debret apontou em tal construção imagens etnográficas nas quais foram identificados tanto os índios e a natureza exuberante que os circundava ${ }^{336}$, quanto os próprios viajantes inseridos neste quadro como observadores, que venciam obstáculos para ver de perto os hábitos dos "sauvage brésilienne." 337 No entanto, e a despeito das intenções de produzir uma história do desenvolvimento progressivo da civilização "brasileira" começando pela análise dos selvagens, Debret entrevia a inserção do Brasil no grupo de nações civilizadas do antigo continente:

\footnotetext{
${ }^{334}$ J. B. Debret. Voyage Pittoresque..., cit. p. I. "cenas nacionais ou familiares do povo".

${ }^{335}$ Ibidem, p. III. "uma descrição fiel do caráter e dos hábitos dos brasileiros em geral."

${ }^{336}$ A respeito do "discurso etnográfico" ou "heterologia" como elementos da literatura de viagem ver Michel de Certeau. Etno-grafia: a oralidade ou o espaço do outro. In: A escrita da história. Rio de Janeiro: Forense-Universitária, 1982.; F. Fernandes. Um balanço crítico das contribuições etnográficas dos cronistas. In: Investigação etnológica. Petrópoles: Vozes, 1975.

${ }^{337}$ J. B. Debret. Voyage Pittoresque..., cit.p. III. "selvagem brasileiro"
} 
Protéges par Le gouvernement et encouragès à perfectionner leur industrie au sein de leurs habitude, deviendront le plus fermes soutiens de la prospérité du Brésil, déja riche de la fertilité de son sol et de la fécondité des nombreux animaux utiles qui s'y trouvent dissemines [...] Par l'effect de la civilisation, la race indinne doit acquérir, selon nous, une amélioration sensible, en se fondant peu à peu dans la race brésilienne d'origine européenne nous em sommes d'autant plus convaincu, qu'il existe dans lês provinces de San-Paulo et de Minas de três-belles famillies de race mèlée, issues de l'union blanes et de femmers cabocles ${ }^{338}$

Ainda que sua análise encerre cenas do cotidiano e do ambiente em que os indígenas estavam inseridos, a participação destes indivíduos na formação nacional do Brasil não está restrita na sua obra a parâmetros estritamente poéticos, comuns neste tipo de literatura. As observações a respeito do modo de vida do "sauvage brésilienne" podem de certa forma, fazer jus ao título de pintor de história que é dado a Debret, porém fazem parte também de uma trama que envolve os "primeiros habitantes" do país no processo civilizatório do qual os estrangeiros também faziam parte. O próprio termo "brasileiro" que Debret atribui ao selvagem configura uma posição se não de destaque, ao menos de influência na formação da identidade nacional brasileira a ser constituída. Com a proposta de acompanhar a marcha da civilização de uma nação ainda na infância, segundo ele, parece pertinente que sua obra comece reproduzindo as tendências instintivas do indígena selvagem e ressaltando todos os seus progressos na "l'imitation de l'industrie du colon brésilien", herdeiro das tradições da "mére patrie."339

Tal qual um pintor escritor preocupado em expor a realidade do Brasil, Debret se utilizou da classificação geral da população estabelecida pelo governo português, fundada de acordo com o grau de civilização. Nesta o "Portugais d'Europe" é o português legitimo ou "filho do reino" e o "Brésilien" é o "português nascido no Brasil", aquele de descendência mais ou menos longínqua, enraizado no país. ${ }^{340}$ Quanto

\footnotetext{
${ }^{338}$ Ibidem, p. 39. "Protegidos pelo governo e incentivados a aperfeiçoar sua indústria dentro de seus hábitos, esses preciosos indígenas se tornarão os mais firmes sustentáculos da prosperidade do Brasil, já tão ricos pela fertilidade do seu solo e pela fecundidade dos inúmeros animais úteis que nele se acham disseminados [...] Acreditamos que com a civilização a raça índia melhore sensivelmente, fundindo-se pouco a pouco com a raça brasileira de origem europeia, e tanto mais nos convencemos disso quanto existem, nas províncias de São Paulo e de Minas Gerais, admiráveis famílias de raça mestiça, oriundas da união de homens brancos com mulheres caboclas."

${ }^{339}$ Ibidem, p. I. "imitação da atividade do colono brasileiro"; "mãe-pátria".

${ }^{340}$ Ibidem, p. III.
} 
aos mestiços, aos índios e aos negros, esta classificação que identifica a população do Brasil não lhes confere o termo "brasileiro". No entanto, com relação ao mulato "mestiço de branco com negra" - e baseado nas gradações de cor, Debret o insere na ordem social como um semi-africano, dono de temperamento em harmonia com o clima. Ele teria mais energia que o negro e a parcela de inteligência que provinha da raça branca servia para orientar mais racionalmente as vantagens físicas e morais que o colocava numa posição superior. Encontrando-se, portanto entre o branco e o negro na sociedade política do Brasil, o mulato teria mais chances de se libertar da posição indecisa que ocupava na ordem social, posição esta imposta pelo branco. Debret continuava a observar que:

La scession causée par l'orgueil américain du mulátre d'une part, et la fierté portugaise du Brésilien Blanc de l'autre, devient Le motif d'une guerre à mort qui se manifestera long-temps encore, dans lês troubles politiques, entre ces deux races, rivales par vanité. Un troisième motif de dissentiment vient encore desunir lês hommes blancs au Brésil: c'est 1 aprésomption nationale de Portugais d'Europe, toujours infantné de son pays, qui dédaigne d'admettre une différence de couleur dans la génération brésilienne, et la traite ironiquement de mulátre, sans distinction d'origine. ${ }^{341}$

Além das qualidades que o mulato teria devido à mistura com a raça branca, na visão de Debret, a classe dos mulatos, muito acima da dos negros, justamente pelas suas possibilidades naturais, teria maiores oportunidades de se libertar da escravidão. Esta conclusão está baseada na análise dos mestiços "civilizados" nas principais cidades do império, onde inúmeros deles já estariam gozando da estima geral conquistada por êxitos nas ciências, nas artes, na medicina, etc., constituindo um motivo a mais para que a linha de demarcação que a vaidade traçou entre brancos e mulatos desaparecesse. ${ }^{342}$

A peculiaridade da análise de Debret está, portanto, na inserção de elementos estranhos à constituição estritamente branca do "brasileiro" no sistema de referência

\footnotetext{
${ }^{341}$ Ibidem, p. 18. "A cisão provocada pelo orgulho americano do mulato, de um lado, e a altives portuguesa do brasileiro branco, de outro, é motivo de uma guerra de morte que se manifestará durante muito tempo ainda, nas perturbações políticas, entre essas duas raças rivais por vaidade [...] Uma [outra] razão de desentendimento contribui ainda para desunir os homens brancos no Brasil: é a presunção nacional do português da Europa, envaidecido de seu país, que não sabe compreender a diferença de cor da geração brasileira, que a trata ironicamente de mulata, sem distinção de origem.”

342 Ibidem, p. 18-19.
} 
identitária dos habitantes da América portuguesa. Para ele, ainda que a classificação dada pelo governo português desconsidere o nível de civilização do indígena e do mulato, ao menos os progressos alcançados rumo a esta civilização estavam dados, de acordo com a análise "histórica" realizada por ele.

Numa visualização geral, Debret não deixa de dar uma ideia mais abrangente da constituição do "brasileiro", como alguns dos outros viajantes analisados, considerando a peculiaridade de cada região de um extenso território. Neste, a "variété de temperatine explique done aussi la variété bien remarquable qui existe entre lês Brésiliens naturels au chaque province de ce vast empire",fazendo-se presente no caráter moral e físico dos habitantes, que foram submetidos a ela desde o nascimento:

Le Brésilien, généralement bon, est doué d'une conception dont la vivacité se décèle dans sés yeux nous et expressifs, heureuse facilite naturelle, qu'il applique avec succés à la culture des sciences et des arts [...] Ses facultés naturelle declinent em proportion de l'abaissement du sol qu'il habite. D'une complexion, alors, plus faible, et ne conservant, de l'espirit brésilien, que la vivacité, chez d'aautres reúnie à la force, CE n'est pus qu'um homme fertile en projets, subjugue par ses désirs que se succèdent trop rapidement, et dont Il abandonne l'entière exécution, qu'il regarde frivolement comme pévible ou ennuyeuse [...] Il est cependant patient pou les ouvrages manuels. Du rest, Il aime assez le repor, surtout pendant la chaleur dujour, s'excusant sans cesse sur Le mauvais état de as santé, dont Il parout affligé por Le moment, mais qu'il oublie bientôt en s'égayant par une saillie ou une médisance ingénieuse, dont Il vous recommande Le secret pour la forme. ${ }^{343}$

Baseando-se nas variações de temperatura, Debret afirmava ser fácil compreender que as forças físicas ficassem debilitadas num clima continuamente quente e úmido,

\footnotetext{
${ }^{343}$ Ibidem, p. 19. "variedade de temperatura explica, também, a variedade notável que existe entre os brasileiros de cada uma das províncias desse vasto império"; "O brasileiro, geralmente bom, é dotado de uma vivacidade que se vislumbra nos seus olhos pretos e expressivos, feliz disposição natural que ele aplica com êxito no cultivo das ciências e das artes [...] Suas faculdade mentais declinam na proporção da menor altitude em que habita. Mais fraco, então, e conservando apenas a vivacidade do espírito brasileiro, nos outros unidas à força, não passa de um homem fértil em projetos, subjugado pelos seus desejos, que se sucedem demasiado rapidamente e cuja execução ele abandona por completo, julgando-a frivolamente penosa ou aborrecida [...] É, no entanto, paciente nos trabalhos manuais. Aliás, gosta bastante do repouso, principalmente durante as horas quentes do dia, desculpando-se sem cessar com sua má saúde, de que parece afligir-se no momento mas que esquece logo par divertir-se com uma piada ou uma maledicência engenhosa cujo segredo recomenda 'pro-forma'."
} 
tornando o homem preguiçoso, embora dotado de um espírito penetrante. Apesar das capacidades físicas limitadas pelo clima, advertia que o habitante do Brasil andava de cabeça erguida e se sentia orgulhoso de sua erudição; era o homem que em três séculos teria vivido toda a civilização que a Europa havia construído, podendo em pouco tempo apresentar rivais no talento, como fez a América do Norte em seus modelos de virtude. $^{344}$

Ao descrever a situação dos índios e os detalhes para ele raros e quase ignorados da população do Brasil que esteve sujeita ao jugo português, e se ocupando, ainda mais, da história política e religiosa agitada desde 1789, constituiria, segundo Debret, quadro interessante que poderia restabelecer os traços dos primeiros passos que trouxeram esse povo "recém-regenerado" à civilização. Acrescentava que vaidoso do seu próprio impulso, o "bresilien" soube sustentar as consequências desses traços com uma energia orientada, garantia para um futuro glorioso. ${ }^{345}$

Procurando fazer da viagem ao Brasil um modelo da forma como os cientistas europeus civilizados deveriam se relacionar com outros países em estágios inferiores de civilização $^{346}$, Saint-Hilaire tem nas descrições sobre as habitantes da América portuguesa assuntos de destaque nos seus relatos, influenciando sobremaneira a constituição de obras sobre o Brasil do século XIX:

“j’y jetterai un coup d'oeil sur l'état de la religion chez lês Brésiliens; jê tâcherai de faire connaitre l'administration civile et judiciaire de leur pays; jê dirai quelles sont lês moeurs et les usages des provinces que j'ai visitée, et jê m'appliquerai a Donner une idée exacte des peupla des sauvages." 347

Reunindo o que mais lhe parecia digno de nota, Saint-Hilaire, enaltecido pelos favorecimentos que conseguiu durante sua viagem, afirmava dar uma ideia exata das áreas que percorreu, denominando o resultado de suas viagens como uma "narrativa histórica".

\footnotetext{
${ }^{344}$ Ibidem, p. 19-20.

${ }^{345}$ Ibidem, p. I.

${ }^{346}$ L. Kury. August Saint-Hilaire, viajante exemplar. Intellèctus Revista Eletrônica, ano II, n¹, 2003. p.1.

${ }^{347}$ A. Saint-Hilaire. Voyage dans les provinces..., cit. p.ix. "[...] lançarei uma vista d'olhos geral sobre o estado da religião entre os Brasileiros; procurarei dar a conhecer a administração civil e judiciária de sua pátria; descreverei os costumes e uso das províncias que visitei; sem esquecer de transmitir uma ideia exata das populações selvagens."
} 
Tal qual, seu relato está repleto de divagações a respeito do estado de civilização do Brasil e descrições dos lugares que percorreu, transportando-se sempre à época da viagem. Talvez por isso não esteja presente no relato analisado uma análise mais sistemática de quem eram os "brasileiros", tendo, por sua vez, indicações de expressões identitárias dissipadas, como "brasileiro", "português", "mineiro", "americanos", "sertanejos", "luso-brasileiros", "brasileiros portugueses", anunciadas ao sabor das experiências que obteve ao longo da viagem. Mesmo que não estejam dispostos dentro de uma lógica específica ou distinguidos com relação às gradações de cor, de posição social ou divisões de raça, o fato é que o viajante apresentou uma profusão de termos relacionados ao conjunto humano componente do universo luso americano.

Assim como seus contemporâneos que empreenderam viagens pelo Brasil, SaintHilaire ensaiava expressões identirárias como "Portugais européens". Referindo-se a estes como indivíduos de classe baixa que iniciaram suas fortunas como donos de vendas, ele afirmava serem homens que se distinguiam por uma extrema economia, aproveitando-se da espécie de renúncia que ele observava nos "Americains". Porém, os parcos bens que os "Européens" conseguiam acumular não eram muito frequentemente dissipados por seus descendentes que "nés em Amérique, prennent lês moeurs et l'espirit de leur patrie; et l'on voit ainsi se vérifier ce proverbe repete chez lês Brésiliens: o pai taberneiro; o filho cavalheiro; o neto mendicante."348 Os homens que povoaram o Brasil, não traziam de sua pátria quando chegavam à América fugidos dos rigores da justiça ou para enriquecer, segundo ele, senão ideias obscuras e desregramentos que deveriam ter sido superados, apesar dos fracos princípios de moral recebidos durante a primeira juventude, sabendo-se que Portugal era um dos países da Europa em que a ignorância e a superstição mais alteraram a pureza do cristianismo. $\mathrm{O}$ desprezo pela moral, segundo o viajante, tornara-se universal entre eles e a introdução da escravatura e a corrupção geral que a corte de Portugal disseminou no período em que esteve no Brasil agravaram ainda mais este fato, sendo o relaxamento já parte dos costumes. $^{349}$

Não está explícito no relato analisado se os "Portugais européenne" e os "premiers habitants du pays" constituíam para Saint-Hilaire o mesmo grupo de pessoas, ou ainda se aqueles estariam fazendo referência aos que se instalaram no Brasil com a vinda da

\footnotetext{
${ }^{348}$ Ibidem, p. 65. "nascidos na América, adquirem os hábitos e o espírito de sua pátria; e assim se verifica o provérbio repetido pelos Brasileiros: o pai taberneiro; o filho cavalheiro; o neto mendicante."

${ }^{349}$ Ibidem, p. 178.
} 
corte e estes os que teriam como descendentes os "brasileiros". O que ele expunha é que os "portugueses europeus", casando-se e tendo filhos - mesclando-se com os indígenas e com os negros - era raro que tivessem vindo à América para aí se fixar definitivamente, querendo, ao contrário, acumular riquezas para ostentá-las às vistas de seus compatriotas, sem perceber o tempo que passavam longe da pátria. Diante das circunstâncias, Saint-Hilaire apontava que durante este intervalo, seus filhos não teriam qualquer laço afetivo com Portugal, ficariam fatigados de ouvir falar num país que não conheciam. Ficariam naquele em que nasceram, fazendo-se desta forma o povoamento no Brasil, e acostumados com as práticas imperfeitas dos primeiros habitantes, as perpetuariam até aquele momento. ${ }^{350}$ Como características gerais atribuídas aos descendentes dos primeiros habitantes, a quem podemos considerar que sejam os "brasileiros", ele escreve:

Les premiers habitans du Brésil onte été, pour la plupart, des hommes d'une condition basse, accoutumés " une extrême sujétion; ils ont communiqué à leurs descendans leur espirit de servilité, et cet espirit est encore entretenu par ceux qui arrivent tous les jour de Portugal, et ne sont pás d'une classe plus élevée qui leurs devanciers. Dans un supérieur qui descend jurque’à eux, ils croient voir un homme qui se rend justice, et ils le mépresent." 351

Quanto aos "Américain", Saint-Hilaire se refere a eles como uma raça muito diferente dos europeus. Voltando de um passeio, o viajante teria encontrado no engenho onde se hospedava homens que havia reconhecido como indígenas. Aos traços dos que ele denominava como sendo pertencentes à raça "américain", a quem os portugueses chamavam de Coroados, tão diferentes dos seus próprios traços, comentava, acrescentava uma fealdade peculiar àquela nação indígena: eram de estatura pequena, cabeça achatada em cima e de um tamanho enorme, a nudez quase completa deixava a descoberto sua sujeira e longos cabelos negros caiam em desordem sobre os ombros. ${ }^{352}$ Observando outras nações indígenas, reconhecia os mesmos traços que encontrara nos

\footnotetext{
${ }^{350}$ Ibidem, p. 192.

351 Ibidem, p. 357. "Os primeiros habitantes do Brasil foram, na maioria, homens de baixa condição, acostumados à extrema sujeição; comunicaram a seus descendentes esse espírito de servilismo, que ainda reforçado pelos que constantemente chegam de Portugal, e não pertencem a classe superior à de seus antecessores. Em um superior de desce até eles, julgam ver um homem que se considera de seu próprio nível, e tratam-no com pouca consideração."

352 Ibidem, p. 37-38.
} 
Coroados, todos os que lhe "paraissent caractériser le plus généralemente la race américaine" e constatou só existirem diferenças entre as variações de nações da mesma raça. $^{353}$

Nessa análise sobre a raça "americana" não estão incluídos os mulatos. Ao observar dois jovens, filhos de um capitão da nação indígena dos Malalís, teria constatado diferenças com relação aos Coroados que lhe chamaram a atenção: não pareciam ter nada em suas fisionomias que os identificassem como indivíduos "américain", assemelhando-os com qualquer coisa dos traços e cor dos mulatos, que poderia ser explicada, a seu ver, pelas relações que os Malalís tinham com negros fugidos. ${ }^{354}$

As diferenças dentro do grupo dos "americanos" não paravam por aí: a cor dos Índios era um assunto que rendia certa curiosidade, ao constatar a existência de índios Botocudos à margem do Jequitinhonha quase brancos, chegando a presenciar uma jovem desta nação indígena, que além de não ter a tez cobreada, como outros índios, apresentava a face corada. À cor cobreada dos índios ele atribuía ao resultado da imundice, ao ardor do sol e a todos às intempéries a que estavam expostos:

Voice encore un fait qui tend à confirmer ce que j'avance ici. Lorsque j'étais dans lês Minas Novas, je vi un june mulâtre qui, avec lês cheveux crépus des nègres, avait une figure fort agréable et tous lês traits des Européens [...] Se peau, qui restrait exposée à l'ardeur du soleil et à une poussière très-abondant, était d'une teinte aussi cuivrée que celle des Indiens qui ont la couleur la plus obscure; et certainement ce jeune homme n'appartenait nullement à la race américaine. $^{355}$

Com relação aos homens de cor, Saint-Hilaire apontava como destino a extinção das nações selvagens por meio da aproximação com nações mais civilizadas, encorajando a união legítima das Índias com os brancos, obtendo-se por este meio uma

\footnotetext{
${ }^{353}$ Ibidem, p. 424. "pareciam caracterizar com maior generalidade a raça americana".

${ }^{354}$ Ibidem, p. 425.

${ }^{355}$ Ibidem, p. 426. "Eis um fato que tende a confirmar o que aqui deixo escrito: Quando estava em Minas Novas vi um jovem mulato que, aos cabelos crespos dos negros, reunia uma fisionomia bastante agradável e todos os traços dos Europeus [...] Sua pele que ficava exposta ao ardor do sol e a uma poeira muito abundante, era de coloração tão escura como a dos Índios de cor mais carregada; e certamente esse jovem não pertencia de forma alguma à raça americana."
} 
raça mista menos defeituosa que a "américain" pura e o que restasse dos Índios não ficaria completamente perdido num país em que havia tão grande falta de homens. ${ }^{356}$

Podemos perceber que o viajante utiliza do termo "americano" para fazer referência aos indígenas, não havendo um termo específico para definir os indivíduos decorrentes do "melhoramento" das nações selvagens por meio da miscigenação com os homens de cor. ${ }^{357}$ Assim, algumas indefinições com relação aos "americanos" acompanham seu raciocínio: ao observar que estaria no próprio interesse do governo preparar paulatinamente os povos para terem liberdade - especialmente no Brasil, onde o povo, degradado pela escravidão, não seria tratado de uma hora para outra como se sempre tivesse tido a tradição de um governo livre - constatava que se D. João VI, ao chegar ao Rio de Janeiro, "avait donné à sés sujets américains des instituitions qui eussent été en harmonie avec Le nouvel ordre de choses", o Brasil não teria passado pelas vicissitudes que, segundo ele, por pouco não causaram sua perda. ${ }^{358} \mathrm{O}$ termo "americano", aqui considerando a generalidade desta passagem do relato ao se referir à instituições políticas, e estando relacionado ao termo "súdito", não pode estar fazendo alusão única e exclusivamente aos indígenas. O termo, neste sentido, está mais voltado ao grupo heterogêneo composto pelos "vassalos" do rei, incluído aí todos os que viviam em território luso americano.

Portanto, podemos concluir que Saint-Hilaire na profusão de identidades mencionadas no seu relato, tem no termo "brasileiro" um tipo específico de português, descendente daqueles primeiros habitantes do país, enquanto que "americano", num sentido mais restrito, significava os naturais do país sem qualquer conexão com sangue europeu ou africano - indígenas -, e, num sentido mais amplo, fazia referência aos habitantes da América portuguesa como um todo, tendo neste sentido, e para todos os efeitos, um “brasileiro".

Interlocutor de Saint-Hilaire e Debret, Ferdinand Denis também empreendeu uma apreciação bastante ampla de diversos aspectos do Brasil na sua viagem pelo país. Assim como seus conterrâneos, a constituição dos habitantes do Brasil foi assunto de seu interesse, na qual identificou diversas "raças" às quais fariam parte.

\footnotetext{
${ }^{356}$ Ibidem, p. 51.

357 No quadro estatístico que Saint-Hilaire apresenta da população da região das Minas, as únicas diferenciações encontradas nas expressões identitárias são "brancos", “índios”, "mulatos livres", "mulatos escravos", "negros livres" e "negros escravos". Ibidem, p 325.

${ }^{358}$ Ibidem, p. 357. "tivesse dado a seus súditos americanos instituições que estivessem em harmonia com a nova ordem de coisas"
} 
Mesmo diante da afluência de estrangeiros e do caráter europeu dado ao Rio de Janeiro, Denis notava que a população não apresentava menos seu caráter original, apesar de muito misturada, em razão da diversidade de cores e raças que a cada instante se fazia presente. Segundo ele, a classe que há pouco tempo podia se distinguir das demais por seu porte e costumes de autoridade eram os portugueses "puros" ou "filhos do reino". Os "brésilien" vinham depois destes, segundo Denis, quanto à espécie de inferioridade que se estabelecia entre os dois grupos. Interessante notar que na análise de raças de Denis, o "brasileiro" enquanto termo genérico, designava todas as misturas de raças, distinguindo-se os mulatos, que eram provenientes da mistura de brancos e negros, e os mamelucos, provenientes da mistura de brancos e índias. Quanto aos negros, o viajante fazia distinção entre os nascidos na África e os nascidos no Brasil, denominados estes de "crioulos", únicos que recebiam uma denominação reservada em relação aos brancos nascidos no país." $" 359$

Os preconceitos relacionados à cor devido à mistura que desde a origem se tinha necessariamente efetuado, deveriam desaparecer completamente no Rio de Janeiro, segundo o viajante, assim como em outras capitais de província que compunham o Império. Isto talvez se devesse à apreciação feita por ele com relação à preparação para a emancipação, efetuadas particularmente no Rio e na Bahia, onde o expediente adotado era o de igualar os pretos a outras classes. Sobre isto comentava que não era necessária uma observação muito atenta para distinguir ente algumas raças de pretos uma posição reservada à povoação branca, como certos comandos de regimentos e o direito de alguns em receber ordenamentos religiosos e celebrar missas. ${ }^{360}$ A composição racial da população parece ter sido de mais valia para Denis na análise sobre a constituição do ambiente sócio-político no Brasil, sendo a qualificação do mulato, segundo ele, pertencente muito mais à legislação que à fisiologia. A este respeito, o viajante comentava que no Brasil a questão da raça teria se transformado em questão de ódio, na medida em que os europeus se congratulavam de uma origem que, na verdade, em nada acrescentava em seus direitos. Contrariamente às leis, mas ação muito praticada, o título de branco sem mescla era concedido pelo Estado e mesmo pela sociedade a todo individuo que apresentasse qualquer nuance da raça branca. ${ }^{361}$

\footnotetext{
${ }^{359}$ F. Denis. Brésil... , cit. p. 124-125.

${ }^{360}$ Ibidem, p. 125.

${ }^{361}$ Ibidem, p. 158.
} 
As mudanças na política do país foram devidas, segundo Denis, à denominação de mulato imprudentemente adotada pelo Estado a respeito da população no Brasil. Para ele, a influência do "mulato puro" nas atividades políticas era fato evidente, devido a sua constituição física essencialmente forte, sua mobilidade e inteligência, fazendo dele um participante apropriado de revoluções. ${ }^{362} \mathrm{Em}$ interlocução com outros viajantes, como Koster e Debret, dos quais extraiu trechos a respeito dos mulatos na sociedade luso americana, Denis ressaltava a constituição racial do Brasil em face das desavenças políticas que a formação "pura" dos "portugueses" (filhos do reino) trazia para a sociedade. A colocação do "brasileiro", entendida por ele como a mistura de todas as raças, colocava especialmente o mulato numa posição se menos privilegiada que a dos "portugueses", ao menos em situação de disputa com os puramente brancos. Portanto, a divisão entre "brasileiros" e "portugueses", do ponto de vista legal e político perspectiva do autor - a princípio não teria qualquer mérito, sendo o preconceito intricado na população o responsável pela distinção entre ambos.

A partir de convergências nas narrativas de viagem enquanto gênero literário, que condensa suas próprias particularidades, cada viajante a sua maneira expôs os exemplares humanos do Brasil e seus costumes a partir de subjetividades que refletiram tanto a forma de escrita quanto a própria descrição da sociedade luso americana. $\mathrm{O}$ fato dos viajantes expressarem em seus discursos feições dos habitantes salienta seus interesses por um grupo humano julgado diferente e inferior aos seus, e análises a respeito da formação de um sentimento nacional em vista dos progressos que o Brasil alcançaria com a ajuda de suas respectivas nações em estágio avançado de civilização. De modo geral, os detalhamentos do feitio, da cor da pele, da classe social, das maneiras, entre tantas outras características identificáveis nos relatos dos viajantes analisados, os aproximam no que diz respeito ao plano discursivo que, independentemente dos objetivos traçados para as viagens, estão voltados ao que era desconhecido e diferente com relação a eles próprios.

Enquanto método de investigação do mundo, os viajantes estiveram em contato com um mundo essencialmente diferente do de origem ao percorrerem o Brasil. Em

\footnotetext{
${ }^{362}$ Ibidem, p. 158.
} 
termos de sociabilidade, se depararam com um país escravista que tinha nas relações sociais uma dinâmica particular, na qual a diferenciação com o outro por meio do "ser português" se tornava ainda mais imperativo, na medida em que o sistema escravista exercia impacto na formação das identidades coletivas e sua politização. De forma direta ou indireta, a formulação de imagens a respeito do Brasil e seus habitantes, nos meandros da transformação política intensa das primeiras décadas do século XIX, contou com a visão externa dos viajantes, resultando em expressões totalizadoras capazes de aglutinar em definições diversas, de acordo com o ponto de vista específico de cada viajante, o que significaria "ser brasileiro", ao passo que a condição de "não ser" permitiu aos estrangeiros se referirem ao "brasileiro" com certa desenvoltura: dado eloquente dessa realidade, ao mesmo tempo elemento criado por ela e a ela devolvido pelos viajantes.

$\mathrm{E}$ ao veicularem expressões que dissessem respeito aos habitantes do Brasil, eles ofertaram a possibilidade discursiva de uma identidade: a alteridade diante da própria identidade do viajante, permitindo a disponibilização de outra identidade para aquele que estava sendo referido nos seus discursos. A partir das generalizações empreendidas pelos viajantes, exemplificadas acima, apesar de extremamente simplificadoras do ponto de vista da complexidade da formação de uma identidade nacional, tem como resultado uma enunciação que sutilmente pode ter tido a capacidade de intervenção numa realidade de intensas transformações políticas, antes mesmo de fazer sentido àqueles referidos na expressão "brasileiros".

E mesmo os casos de escassa possibilidade de "devolução" à sociedade dessas ideias identitárias generalizadoras, é possível pensar que estas já estavam sendo disponibilizadas a todos que vivessem e que atuassem na mesma época, ou seja, já estava presente no universo linguístico dos agentes históricos a noção de uma identidade aglutinadora a sintetizar alguns dos habitantes da América portuguesa no termo "brasileiro", disponibilizado pelos estrangeiros. Estaria sendo dado aquilo que Koselleck chamaria de "condições de possibilidades", de realizações de uma determinada história: a da emergência de uma identidade nacional brasileira. Por meio das visões estrangeiras dos viajantes, estariam sendo estabelecidos os vínculos entre o pensamento social ou político com os sujeitos sociais envolvidos nessa trama, na qual 
"as condições da possibilidade da história real são, ao mesmo tempo, as condições do seu conhecimento." 363

${ }^{363}$ Reinhart Koselleck. Futuro Passado. Contribuição à semântica dos tempos históricos. Tradução, Wilma Patrícia Maas, Carlos Almeida Pereira; revisão César Benjamin. Rio de Janeiro: Contraponto - Ed. PUC-Rio, 2006. p. 309. 


\section{Conclusões}

Nas páginas anteriores, procurou-se observar a construção de identidades coletivas e sua politização nas primeiras décadas do século XIX. O foco do trabalho esteve centrado na investigação das expressões vocabulares empregadas por viajantes estrangeiros, que estiveram no Brasil entre os anos de 1808 e 1822, para se referirem aos seus habitantes. Em termos conclusivos, pode-se dizer que o estudo buscou contemplar os seguintes aspectos, interligados entre si: o estudo do processo de constituição de uma identidade nacional brasileira nas primeiras décadas do século XIX, mais especificamente, a construção vocabular de expressões identitárias em referência aos "brasileiros" por meio de discursos de viajantes estrangeiros que visitaram o Brasil e sobre ele escreveram; e também a percepção da possibilidade de que tais expressões interagiram com o processo mais geral de configuração e politização de uma identidade coletiva que, naquele mesmo período tornar-se-ia referência básica da nação brasileira, que ainda não estava devidamente estabelecida. Tratou-se, enfim, de uma proposta que, por meio de um estudo delimitado e restrito, buscou contribuir com os estudos gerais voltados ao surgimento do Estado e da nação brasileiros nas primeiras décadas do século XIX.

Os discursos dos estrangeiros que estiveram no Brasil nas primeiras décadas dos oitocentos se apresentaram como rico material no que concerne à possibilidade de percepção do outro, com relação aos habitantes da América portuguesa. Isto porque a carga cultural trazida por esses indivíduos na viagem, quando somada ao estranhamento e à análise do diferente, refletida nesse "outro", apresentaram a capacidade de produzir expressões identitárias remetidas às coletividades sociais do Brasil que, em momento oportuno, integrar-se-iam à complexa rede do processo de formação da nação.

Este aspecto guarda relação direta com a compreensão da diversidade de outras identidades já existentes na multifacetada sociedade luso americana do século XIX, no entendimento da construção geral de uma nacionalidade brasileira. A problematização dos vocábulos e dos sentidos dado ao Brasil e aos seus habitantes, como parte de preocupações relevantes para a historiografia que aborda a formação do Estado nacional brasileiro, permitiu a compreensão de termos identitários como "nação", "pátria", "Brasil", "portugueses" e "brasileiros" no período, abarcados pela ótica externa dos viajantes. 
Para o empreendimento proposto na pesquisa, foi necessário tocar em algumas frentes que dessem inteligibilidade ao corpo documental elencado na pesquisa, enquanto gênero literário passível de múltiplas interpretações por quem decide estudá-lo. As discussões em torno da literatura de viagem como fonte e a retórica e linguagem empreendida por seus autores influenciaram a leitura dos textos dos viajantes na medida em que o que se buscou foram as construções de identidades coletivas baseadas na abertura de possibilidades desses sujeitos percorrerem o Brasil. Herdeiros da produção de viagem do século anterior, procurou-se recuperar a importância das linguagens em que os textos foram produzidos, inserindo-os no contexto neocolonialista do século XIX que encerrava nas viagens uma forma de dominação e a oportunidade dos Estados de colocar em prática seus projetos políticos e econômicos.

O cenário em que os estrangeiros viajaram no período proposto, de expansão de influências das potências europeias em regiões onde se apresentava amplo espaço de fundação e aplicação de visões de mundo supostamente superiores, a autodeterminação com frequência inferiorizou uma das partes na relação estabelecida entre visitante e visitado. E nesta dinâmica, a relação identidade e alteridade mostrou-se campo fecundo de análise empírica, na medida em que a criação de juízos e conceitos realizada pelos viajantes teve algum poder prático no processo de formação nacional no Brasil. Esta hipótese é admitida pelo fato de que, ainda que as informações e opiniões veiculadas pelos relatos de viagem envolvam questões que são próprias do gênero literário, tais como a veracidade e a chamada "memória de biblioteca", o detalhamento registrado pela pena dos viajantes engendrou a construção de uma visão específica dos habitantes da América portuguesa que se cristalizou no universo simbólico tanto do europeu quanto do "brasileiro". Para o primeiro, a partir da circulação e do prestígio da produção literária resultante das viagens, e, para o segundo, pela ressignificação de uma imagem por oposição.

Este último aspecto nos levou à parte principal do trabalho: a criação de imagens do Brasil e dos "brasileiros" nos relatos de viagem das primeiras décadas dos oitocentos. A maneira como os viajantes descreveram os episódios políticos do período, relacionando-os à criação de um sentimento comum, numa coletividade considerada apartada até a vinda da Família Real ao Brasil de qualquer noção de unidade, e a equivalência dos tipos específicos de identidades e sua articulação com as camadas sociais presentes na América portuguesa, nos permitiu observar a definição de uma identidade totalizadora, entre as demais identidades coletivas desse cenário, relacionada 
à configuração de uma futura nacionalidade brasileira. A ideia de Brasil apresentada nos relatos conduziram ao apontamento dos viajantes, mais ou menos geral, da falta de similaridade da população e os esforços de manutenção de uma unidade sob a égide monárquica, muitas vezes colocada em oposição ao que ocorria na vizinha hispânica. Observadas de diversas formas, dentro deste espectro geral, as entidades políticas envoltas nesta busca por uma possível nacionalidade, tiveram na descrição dos "brasileiros" o amálgama imperativo para análises que almejavam conduzir o Brasil no caminho da civilização, tendo na ideia de nação a consolidação de uma unidade.

As diversas formas pelas quais os viajantes europeus deram sentidos e definições para os habitantes luso americanos, em especial ao "brasileiro", apontaram como conclusão para a pesquisa que este interesse acentuado desenvolveu nos estrangeiros uma desenvoltura persuasiva em falar desse homem ao ponto de ter a capacidade, senão de transferência direta à sociedade da qual fala, ao menos uma forma de se pensar sobre ele e a oferta de uma possibilidade discursiva em torno dessa identidade em processo de politização. Nos discursos, considerado palavra escrita e palavra falada, a dimensão da oralidade também é essencial no processo de cristalização dessa identidade, aspecto demonstrável na construção do "ser brasileiro" feita pelos viajantes por disponibilizarem elementos qualitativos a todos que vivessem na mesma época. Nos espaços de sociabilidade, tal introdução de dados novos abordada no trabalho se deu por meios externos, ou seja, abriu discussão para se compreender a identidade a partir do que "não se é" - britânico e francês - ou seja, mais a partir da diferenciação com o outro, do que pela identificação de indivíduos inseridos num mesmo grupo, que no caso do Brasil em inícios do século XIX apresentava sociedade bastante heterogênea e em muitos aspectos desconectada. 


\section{Fontes}

DEBRET, Jean Baptiste. Viagem pitoresca e histórica ao Brasil.2. v. Trad de Sergio Milliet. São Paulo: Martins. 1949. . Voyage Pittoresque et Historique au Brésil, ou séjour d'um Artiste

Français au Brésil, Depuis 1816 junsqu'em 1831 inclusivement, Époques de l'Avénement et de 1' abdication de S.M.D. Pedro I, Foundateur de 1'Empire Brésilien. Paris: Firmen Didot Frèses, 1834-1839, 3 vv.

DENIS. Ferdiand. Brasil. Trad. João Etienne Filho e Malta Lima. Belo Horizonte/São Paulo: Itatiaia/ EDUSP, 1980GRAHAM, Maria. Diário de uma viagem ao Brasil e de uma estada neste país durante parte dos anos 1821,1822 e 1823. Trad. E notas de Américo J. Lacombe. São Paulo: Editora Nacional, 1956.

Brésil. par M. Ferdinand Denis; Colombie et Guyanes, Par M. C. Famin. Paris, Firmin Didot frères, éditeurs, MDCCCXXXVII.

GRAHAM, Maria. Diário de uma viagem ao Brasil e de uma estada neste país durante parte dos anos 1821,1822 e 1823. Trad. e notas de Américo J. Lacombe. São Paulo: Editora Nacional, 1956

. Journey of a voyage to Brazil and residence there during parto $f$ the years 1821, 1822 e 1823. Londres: Longman, Hurst, Rees, Orme, Brown and Green, Paternoster-Row, and J. Murray, 1824.

KOSTER, Henry. Viagens ao nordeste do Brasil. São Paulo: Ed. Nacional, 1942. . Travels in Brazil. Londres: Londres: Longman, Hurst, Rees, Orme, Brown and Green, Paternoster-Row, 1816.

LUCCOCK, John. Notas sobre o Rio de Janeiro e partes meridionais do Brasil. Tomadas de uma estada de dez anos neste país, de 1808 a 1818. São Paulo: Liv. Martins Ed., 1942.

. Notes of Rio de Janeiro and Southern parts os Brazil; taken during a residence of tem yars in that country, from 1808 to 1818. Londres: Samuel Leigh, 1820.

MAWE, John. Viagens ao interior do BrasilTrad. De Solena Benevides Vianna. Rio de Janeiro: Itatiaia, 1972.

Travels in the interior of Brazil: particulary in the gold and diamond districts of that country. Londres: Longman, Hurst, Rees, Orme, Brown and Green, Paternoster-Row, 1812. 
O’NEIL, Thomas. A vinda da Família Real Portuguesa para o Brasil. Trad. Ruth Sylvia de Miranda Salles. José Olympo: Rio de Janeiro, 2007 A concise and accurate account of the proccedings of the Squadron under the command of Rear Admiral Sir Sydney Smith.... Londres: Barfield, 1810.

SAINT-HILlARE, Auguste de. Viagem pela província do Rio de Janeiro e Minas Gerais. Trad. de Vivaldi Moreira. Belo Horizonte/São Paulo: Itatiaia/Edusp, 1975. Voyage dans les provinces de Rio de Janeiro et de Minas Gerais, Paris, Grimbert et dorez, 1830.

TOLLENARE, L. F. de. Notas dominicais: tomadas durante uma viagem em Portugal e no Brasil em 1816, 1817 e 1818. Bahia: Progresso, 1956. Notes dominicales prises pendant um Voyage em Portugal et au Brésil. Ed. et com commentaires Léon Bourdon. Paris, Presses Universitaires de France, 1971-1973, 3 vv.

\section{Bibliografia}

ALBUQUERQUE, Luís. Los "Libros de viaje" como genero literário. In: LUCENAGIRALDO, Manuel, PIMENTEL, Juan (eds.) Diez estúdios sobre literatura de viajes. Madrid: CSIC, Instituto de língua española, 2006.

ALCINA FRANCH, José. El descubrimiento científico de América. Barcelona: Anthropos, 1988.

ALDEMAN, Jeremy. Sovereignty and Revolution in the Iberian Atlantic. Princeton: Princeton University Press, 2006.

ALEXANDRE, Valentim. Os sentidos do império: questão nacional e questão colonial na crise do Antigo Regime português. Porto: Afrontamento, 1993.

ANDERSON, Benedict. Comunidades Imaginadas. Trad. Denise Bottman. São Paulo: Companhia das Letras, 2008.

ARAÚJO, Ana Cristina. A cultura das luzes em Portugal. Temas e problemas. Lisboa: Horizonte, 2003.

vésperas da Independência do Brasil. In: Jancsó, I. Independências: história e historiografia. são Paulo: Hucitec/Fapesp, 2005.

ARRIGHI, Giovanni. O longo século XX: dinheiro, poder e a origem de nosso tempo. Rio de Janeiro/São Paulo: Contraponto/Edusp, 1996. 
AUGEL, Moema Parente. Visitantes estrangeiros na Bahia oitocentista. São Paulo/Brasilia: Cultrix/INL, 1980.

BAKHTIN, Mikhail. Estética da criação verbal. 4 ed. São Paulo: Martins Fontes, 2003.

BALAKRISHNAN, Gopal (org.). Um mapa da questão nacional. Trad. Vera Ribeiro. Rio de Janeiro: Contraponto, 2000.

BARREIRO, José Carlos. Imaginários e viajantes no Brasil no século XIX: cultura e cotidiano, tradição e resistência. São Paulo: Unesp, 2002.

BELluZZO, A. M. M.. O Viajante e a Paisagem Brasileira. Porto Arte (UFRGS), v. 25, p. 41-57, 2008.

Objetiva/Metalivros, 1999.

A paisagem brasileira através do olhar britânico. In: Carlos Eugênio Marcondes de Moura. (Org.). Brasil: Grã-Bretanha: uma relação de cinco séculos. São Paulo: Ed. do Autor, 2010, v. , p. 96-123.

BERBEL, Márcia. Os apelos nacionais nas Cortes Constituintes de Lisboa (1821-1822).

In: MALERBA, Jurandir (org.) A independência Brasileira: novas dimensões. Rio de Janeiro: FGV, 2006.

BERNARDES, Denis A. Mendes. O patriotismo Constitucional. Pernambuco. são Paulo: Hucitec/ Fapesp, 2006.

BICALHO, Maria Fernanda. A cidade e o império. O Rio de Janeiro no século XVIII. Rio de Janeiro: Civilização Brasileira, 2003.

BOURDIEU, Pierre. O poder simbólico. 2 ed. Trad. Fernando Thomaz. Rio de Janeiro: Bertrand Brasil, 1998. A economia das trocas linguísticas: o que falar quer dizer. Trad.

Sérgio Miceli. 2 ed. São Paulo: Edusp, 1998.

BOXER, C. R.. O Império colonial português (1415-1825). Lisboa: Edições 70, 1981.

BRANDÃO, Carlos. Identidade e etnia: construção da pessoa e resistência cultura. São Paulo: Braziliense, 1986.

BRAUDEL, Fernand. Civilização material, economia e capitalismo, séculos XV-XVIII. Trad. de Telma Costa. 3 v. São Paulo: Martins Fontes 2009.

BURKE, Peter. As fronteiras instáveis entre História e ficção. In: AGUIAR, Flávio, MEYHI, Jose C.S.B., VASCONCELOS, Sandra Guardini. T. (orgs.) Gêneros de fronteira. Cruzamento entre o histórico e o literário. São Paulo: Xamã, 1997.

CALMON, Pedro. História do Brasil. Rio de Janeiro: José Olímpio, 1959, vol. IV. 
CANDIDO, Antônio. Formação da literatura brasileira. Belo Horizonte: Itatiaia, 1981.

CARELLI, Mario. Culturas cruzadas. Intercâmbios culturais entre França e Brasil.

Trad. de Nicia Adam Bonatti. Campinas: Papirus, 1994.

CARRICHIO, Paula Botafogo. Redatores no Rio de Janeiro e deputados nas Cortes de Lisboa pela construção da monarquia constitucional portuguesa (1821-1822). Tese (doutorado). São Paulo, USP-FFLC, 2011.

CARVALHO, José Murilo de Carvalho. Brasil. Naciones Marginadas. In: Antonio Annimo; Luis Castro Leiva, François-Xavier Guerra (dir.) De los impérios a las naciones Iberoamérica. Zaragoza/Espanha: Ibercaja, 1994.

CARVALHO, Marieta Pinheiro de Carvalho. Uma ideia ilustrada da cidade: as transformações urbanas no Rio de Janeiro de D. João VI (1808-1821). Rio de Janeiro: Odineia, 2008.

CASTRO, Zília Osório de. A independência do Brasil na imprensa periódica portuguesa (1822-1823). Revista de História das Ideias, vol. 15, 1993.

CHATIER, Roger. A história cultural. Entre práticas e representações. Trad. Maria Manuela Galhardo. Lisboa-Rio de janeiro: Difel-Bertrand Brasil, 1990. Que és um texto. Madri: Circulo de Bellas Artes, 2006. A ordem dos livros: leitores, autores e bibliotecas na Europa entre os séculos XIV e XVIII. Trad. Mary del Priore. Brasília: UnB, 1999.

CHAVES, Castelo Branco. Os livros de viagem em Portugal no século XVIII e sua projeção europeia. 2 ed. Lisboa: Instituto de Cultura e Língua Portuguesa, 1987.

CHIARAMONTE, J. C.. Cidades, Províncias, Estados. Origens da Nação Argentina (1800-1846). São Paulo: Hucite, 2009. . Metamorfoses no conceito de nação. In: CHIARAMONTE, José Carlos (org.). Brasil: formação do Estado e da Nação. São Paulo: Hucitec, 2003. - "Formas de identidad politica em el Rio de la Plata luego de 1810.”In: Boletin del Instituto de Historia Argentina e Americana “Dr. Emilio Ravignani”, 3 série, $\mathrm{n}^{\circ}$ 1, Buenos Aires, 1989.

Modificaciones del Pacto Imperial. In: Antonio Annimo; Luis Castro Leiva, François-Xavier Guerra (dir.) De los impérios a las naciones: Iberoamérica. Zaragoza/Espanha: Ibercaja, 1994.

CONDORCET, Marques de. Esboço de um quadro histórico dos progressos do espirito humano. Trad. Carlos Alberto Ribeiro de Moura. Campinas: Unicamp, 1993. 
COSTA, Wilma Peres. Viagens e peregrinações: a trajetória de intelectuais de dois mundos. In : BASTOS, Élide Rugai; RIDENTI, Marcelo; ROLLAND, Denis (orgs.) Intelectuais: Sociedade e política. São Paulo: Cortez, 2003. - Viajantes europeus e o escrever da nação brasileira. In: PAMPLONA, Marco \& DOYLE, Don (orgs.) Nacionalismos no Novo Mundo - a formação de Estados-nação no século XIX. Rio de Janeiro: Record, 2008.

CORTESÃO, Jaime. História do Brasil nos velhos mapas. Rio de Janeiro: Ministério das Relações Exteriores, Instituto Rio Branco, 1965.

DANTAS, Monica Duarte. Boa gente brasileira: homens livres, pobres e libertos e escravos no Brasil do século XIX. São Paulo: Escolas Associadas, 2003.

DIAS, Maria Odila da Silva. A interiorização da metrópole e outros estudos. 2ed. São Paulo: Alameda, 2009.

DOMINGUES, Ângela. O Brasil nos relatos de viajantes ingleses do século XVIII: produção de discursos sobre o Novo Mundo. Revista Brasileira de História (online). 2008, vol.28, n.55. p. 133-152.;

- Notícias do Brasil Colonial: a imprensa cientifica e política a serviço das elites (Portugal, Brasil e Inglaterra). Varia História (onlne). 2006, vol. 22. p.

ELIAS, Nobert. O processo civilizador. Uma história dos costumes. Trad. De Ruy Zungman. 2 ed. Rio de Janeiro: Jorge Zahar, 1994, 2 vols.

FAIRCLOUGH, Norman. Discurso e Mudança Social. Brasília: EdunB, 2001.

FILHO, Amilcar Torrão. A arquitetura da alteridade. A cidade luso-brasileira na literatura de viagem (1783-1845). São Paulo: HUcitec/Fapesp, 2010.

FRAGOSO, João. Homens de grossa ventura: acumulação e hierarquia na praça mercantil do Rio de Janeiro (1790-1830). Rio de Janeiro: Arquivo Nacional, 1992.

BATISTA,M. Fernanda \& GOUVEA, Maria de Fátima (orgs.). O Antigo Regime nos Trópicos: A Dinâmica Imperial Portuguesa (séculos XVI e XVII). Rio de Janeiro: Civilização Brasileira, 2001.

FRANÇA, Jean Marcel Carvalho. A construção do Brasil na literatura de viagem dos séculos XVI, XVII e XVIII. Antologia de textos. 1591-1808. Rio de Janeiro: José Olympo; São Paulo: Unesp, 2012.

FREIRE, Gilberto. Ingleses no Brasil. Rio de Janeiro: José Olímpio, 1948. 
GELLNER, Ernest. Nações e Nacionalismos. Trad. Inês Vaz Pinto. Lisboa: Gradiva, 1993.

GERBI, Antonello. O novo mundo. Historia de uma polêmica (1750-1900). Trad. de Bernardo Jofilly. São Paulo: Cia das letras, 1996.

GOUVÊA, Maria de Fátima. O império das provinciais. Rio de Janeiro (1822-1889). Rio de Janeiro: Faperj, 2006

GREENE, Jack P.. Reformulando a identidade inglesa na América britânica colonial: adaptação cultural e experiência provincial na construção de identidades corporativas. Almanack Braziliense (Online), São Paulo, v. 4, 2006.

GODINO, Vitorino Magalhães. Os Descobrimentos e a Economia Mundial. 4Vols. Lisboa: Presença, 1987.

GOODMAN, Eduard J. The explorers of South America. Norma, London: University of Oklahoma. Press, 1992.

GOUVÊA, Maria de Fátima. O império das províncias. Rio de Janeiro (1822-1889). Rio de Janeiro: Faperj, 2006.

GUERRA, François-Xavier. A nação na América espanhola: a questão das origens. Revista Maracanan. Publicação do Programa de Pós-graduação em História Instituto de filosofia e Ciências Humanas/UERJ. ano I. n.1. 1999/2000.

\section{Modernidad y Independencias. Ensayos sobre las} revoluções hispánicas. Madri: Mapfre, 1992.

A nação moderna: nova legitimidade e velhas identidades.

In: I. Jancsó (org.). Brasil: formação do Estado e da nação. São Paulo: Hucitec, Fapesp, 2003

HALBWACHS, Maurice. A memória coletiva. Trad. Laurent Léon Schaffter. São Paulo: Vértice, 1990.

HARTOG, François. O espelho de Heródoto. Ensaio sobre a representação do outro. Trad. Jacynto Lins Brandão. Belo Horizonte: UFMG, 1999.

HESPANHA, Antônio Manuel. Problemas de organização política entre Antigo Regime e Liberalismo. In: I. Jancsó (org.). Brasil: formação do Estado e da nação. São Paulo: Hucitec, Fapesp, 2003.

Caleidoscópio do Antigo Regime. São Paulo: Alameda, 2012

Poder e instituições na Europa do Antigo Regime: coletâneas de textos. Lisboa: Fundação Calouste Gulbenkian, 1984. 
HOBSBAWM, Eric. Nações e nacionalismos desde 1780. Programa, mito e realidade. Trad. Maria C. Paoli e nna Maria Quirino. 5 ed. Rio de Janeiro: Paz e Terra, 1990. HOLANDA, Sérgio Buarque de.. A herança colonial - sua desagregação. História geral da civilização brasileira t. II. O Brasil monárquico. São Paulo: Difel, 1962. Capítulos da literatura colonial. São Paulo: Braziliense, 1991. Raízes do Brasil. 26 ed. São Paulo: Cia das letras, 1995.

IANN, Octávio. A ideia de Brasil moderno. São Paulo: Braziliense, 1996.

JANCSÓ, István. A construção dos Estados nacionais na América Latina apontamentos para o estudo do império como projeto: In: SZMRECSÁNVI, Tamás \& LAPA, José Roberto do Amaral (orgs.). História econômica da Independência e do Império. São Paulo: Hucitec, Edusp, Imprensa Oficial, 2002. . (org.). Independência do Brasil: história e historiografia. São Paulo: Hucitec/Fapesp, 2005.

Brasil: formação do Estado e da nação. São Paulo: Hucitec, Fapesp, 2003.

A sedução da liberdade: cotidiano e contestação política no final do século XVIII. In: Laura de Melo e Souza (org.) História da vida privada no Brasil. cotidiano e vida privada na América portuguesa. Vol 1. São Paulo: Cia das Letras, . "A hipótese do auxílio francês ou 'a cor dos gatos"”. FURTADO, J. (org.). Diálogos oceânicos: Minas Gerais e as novas abordagens para uma história do Império ultramarino português. Belo Horizonte: EDUFMG, 2001.

. \& PIMENTA, João Paulo G.. Peças de um mosaico (ou apontamentos para o estudo da emergência da identidade nacional brasileira). Revista de História das Ideias (Coimbra), Coimbra, v. 21, p. 389-440, 2000.

KANTOR, Íris. Esquecidos e renascidos: historiografia acadêmica luso americana (1724-1759). São Pulo: Hucitec, 2004.

KOSELLECK, Reinhart. Crítica e crise: uma contribuição à patogênese do mundo burguês. Rio de Janeiro: Eduerj-Contraponto, 1999.

Futuro Passado: contribuição à semântica dos tempos históricos. Rio de Janeiro: Contraponto Editora; Editora PUC Rio, 2006.

LA CAPRA, Dominick. History and Criticism. Ithaca, NY, London: Cornell University Press, 1985. 
LEITE, Miriam L. Moreira. Livros de Viagem (1803-1900). Rio de Janeiro: UFRJ, 1997.

- Literatura de Viagem: características de uma documentação. Notícia Bibliográfica e Histórica, Campinas, SP PUCCamp, v. XIII, n. 104, p. 212-229, 1981.

- A condição humana no século XIX no Rio de Janeiro:

antologia de textos de viajantes estrangeiros. São Paulo: Hucitec/INL/Fundação Nacional Pró-Memória, 1984.

LEITE, Dante Moreira. O caráter nacional brasileiro: história de uma ideologia. 5 ed. São Paulo: Ática, 1992.

LÉVI-STRAUSS, Claude. Tristes Trópicos. São Paulo: Cia das Letras, 2005.

LIMA, Luiz Costa. O controle do imaginário. Razão e imaginação dos tempos modernos. 2 ed. Rio de Janeiro: Forense Universitária, 1989.

LIMA, Manoel de Oliveira. D. João VI no Brasil. Rio de janeiro: Topbooks, 1996.

LIMA, Maria Emília Amarante Torres Lima. As caminhadas de August de Saint-Hilarie pelo Brasil e Paraguai. Belo Horizonte: autêntica, 2002.

LIMA, Valéria. J.-B. Debret, historiador e pintor: a viagem pitoresca e histórica ao Brasil (1816-1819). Campinas-SP: Editora da Unicamp, 2007.

LIMA, Manuel de Oliveira. D. João VI no Brasil. $3^{\mathrm{a}}$.ed. Rio de Janeiro, Topbooks, 1996.

LYRA, Maria de Lourdes V. A utopia do poderoso império. Portugal e Brasil: bastidores da política (1798-1822). Rio de Janeiro: sete letras, 1994.

LISBOA, Karen Macknow. A nova Atlântida de Spix e Martius: natureza e civilização na Viagem pelo Brasil (1817-1820). São Paulo: Hucitec, 1997.

. Os olhos estrangeiros sobre o Brasil do século XIX. In:

MOTA, Carlos G.. Viagem Incompleta: a experiência Brasileira (1500-2000). A grande transação. 1 ed. São Paulo: Ed. Senac São Paulo, 2000.

Viajantes veem as festas oitocentistas. In: JANCSÓ,

István, KANTOR, Íris. Festa: cultura e sociabilidade na América portuguesa.

São Paulo: Hucitec, Edusp, Fapesp, Imprensa Oficial, 2001.

LOPEZ, Emilio Carlos Rodriguez. Festas públicas, memória e representação: um estudo sobre manifestações políticas na Corte do Rio de Janeiro, 1808-1822. São Paulo: Humanitas, 2004. 
MALERBA, Jurandir. A corte no exílio: civilização e poder no Brasil às vésperas da Independência (1808-1821). São Paulo: Companhia das Letras, 2000.

A Independência brasileira: novas dimensões. Rio de Janeiro:

Editora FGV, 2006.

MANCHESTER, Alan K. Preeminência inglesa no Brasil. Trad. Janaína Amado. São Paulo: Brasiliense, 1973.

MARTINS, Luciana de Lima. O Rio de Janeiro dos viajantes. O olhar britânico (18001850). Rio de Janeiro: Jorge Zahar, 2001.

MATOS, Odilon Nogueira de. A literatura dos viajantes estrangeiros como fonte para nossa história. Separata Memórias da I Semana da História. Franca: Unesp, 1979.

MENDES, Elizabeth de Camargo. Os viajantes do Brasil: 1808-1822. Dissertação (mestrado em História). São Paulo. USP, 1981.

MESGRAVIS, Laima. O viajante e a cidade (A vida no Rio de Janeiro através dos viajantes estrangeiros da primeiro metade do século XIX). Tese (Livre-Docência em História). USP, 1987.

MOREIRA LEITE, M. L. A condição humana no século XIX no Rio de Janeiro: antologia de textos de viajantes estrangeiros. São Paulo: Hucitec/INL/Fundação Nacional Pró-Memória, 1984.

MOUREUA, François. Paradojas brasileñas de la Luces francesas. In: LEAL, Maria Luísa, FERNÁNDEZ, Maria Jesús, GARCIA BENITO, Ana Belén (coords). Invitación al viaje. Mérida: Junta de Extremadura, 2006.

MOTA, Carlos G.. Europeus no Brasil à época da independência. Um estudo. In: MOTA, Carlos G. (org.). 1822: dimensões. São Paulo: Editora perspectiva, 1972. . (org.). Viagens incompletas: a experiência Brasileira (1500-2000).

A grande transação. 2 ed. São Paulo: Ed. Senac São Paulo, 2000.

MOTT, Luiz. Cotidiano e vivência religiosa: entre a capela e calundu. In: Laura de Melo e Souza (org.) História da vida privada no Brasil: cotidiano e vida privada na América portuguesa. São Paulo: Cia. das Letras, 1997.

NAXARA, Maria Regina Capelari. Cientificismo e sensibilidade romântica: em busca de um sentido explicativo para o Brasil no século XIX. Brasília: UNB, 2004.

NEVES, Guilherme Pereira das. Del Imperio Luso Brasileño al Império del Brasil (1789-1822). In: Antonio Annino e François Xavier-Guerra (coords.). Inventando la nación. Iberoamérica siglo XIX. Fundo de Cultura Económica: México, 1996. 
NEVES, Lúcia Pereira das. Corcundas e constitucionais: a cultura política da Independência. Rio de Janeiro: Revan/FAPERJ, 2003.

. "Revolução: em busca de um conceito no império luso-brasileiro (1789-1822)". FERES JR., João \& JASMIM, Marcelo (org.). História dos Conceitos: diálogos transatlânticos. Rio de Janeiro: EDPUC-RJ/Loyola/IUPERJ, 2007, p.129-140.

NICOLAZZI, Fernando. Gilberto Freyre viajante: olhos seus, olhares alheios. In: GUIMARAES, Manoel Luiz Salgado (org.) Estudo sobre a escrita da História. (Anais do Encontro de Historiografia e História Política, 10 e 11 de outubro de 2005. UFRJ.) Rio de Janeiro: 7letras, 2006.

NOVAIS, Fernando A.. Portugal e Brasil na crise do Antigo Sistema Colonial (17771808). São Paulo: Hucitec, 1979.

(dir.). História da vida privada no Brasil v.I: cotidiano e vida privada na América portuguesa. São Paulo: Companhia das Letras, 1997.

ORTIZ, Renato. Cultura brasileira e identidade nacional. 5 ed. São Paulo: Brasiliense, 1994.

PALTI, Elias. La nación como problema. México: FCE, 2003. . El tiempo de la política. El siglo XIX reconsiderado. Buenos Aires: Siglo XXI Editores Argentina, 2007.

PAMPLONA, Marco Antônio. Nación. Brasil. In: SEBASTIAN, Javier Fernández (dir.). Diccionario político y social del mundo iberoamericano . La era de las revoluciones, 1750-1850. Fundación Carolina. Sociedad Estatal de Commemoraciones Culturales. Centro de Estudios Políticos y Constitucionales. Madri, 2009.

PAMPLONA, Marco Antônio. "Considerações e reflexões para uma história comparada". Almanack Braziliense n.4, noviembre/2006.

. \& MÄDER, Maria Elisa de Sá (orgs.). Revoluções de Independências e nacionalismos nas Américas - Nova Espanha (vol. 2). São Paulo: Paz e Terra, 2007.

PIMENTA, João Paulo G.. Portugueses, americanos, brasileiros: identidades políticas na crise do Antigo Regime luso-americano. Almanack Braziliense (Online), São Paulo, v. 3, 2006.

. Estado e Nação no fim dos impérios ibéricos no Prata (1808-1828). São Paulo: Hucitec; Fapesp, 2002. 
. "La independencia de Brasil como revolución: historia y actualidad sobre un tema clásico". Nuevo Topo. Revista de historia y pensamiento crítico, v. 5, p. 69-98, 2008.

- "A independência de Brasil como uma revolução: história e

atualidade de um tema clássico". História da historiografía n.3, setembro/2009, p.53-82. . Brasil y las independencias de Hispanoamérica. Castellón de la Plana, Publicacions de la Universitat Jaume I, 2007.

. "De Raynal a De Pradt: apontamentos para um estudo da ideia de emancipação da América e sua leitura no Brasil”. Almanack Braziliense, v.11, p.88 99, 2010.

PRATT, Mary Louise. Os olhos do império. Relatos de viagem e transculturação. Trd. Jézio Herman Bonfim. Bauru: Edusp, 1999.

PIMENTEL, Juan. Testigos del mundo. Ciência, literatura y viajes em la Ilustración. Madri: Marcial Pons,

POCOCK, J. G. A.. Linguagem de um ideário político. Tradução de Fábio Fernandez. São Paulo: Edusp, 2003.

. Politics, language and time: Essays on political thought and history. Londres/Chicago: The University of Chicago Press, 1989.

PORTER, Andrew. The Oxford History of British Empire. Vol III. Oxford/Nova York: Oxford University Press, 1999.

PRADO JÚNIOR, Caio. Formação do Brasil contemporâneo (colônia). São Paulo: Braziliense-Publifolha, 2000. Evolução política do Brasil: colônia e império. 19 ed. São Paulo: Brasiliense, 1993.

PRADO, Paulo. Retratos do Brasil. Ensaio sobre a tristeza brasileira. 3 ed. São Paulo: D.P.\&C., 1929.

PRATT, Mary Louise. Os olhos do império. Relatos de viagem e transculturação. Trd. Jézio Herman Bonfim. Bauru: Edusp, 1999.

REVEL, Jacques. A invenção da sociedade. trad. Vanda Anastácio. Lisboa/Rio de Janeiro: Difel/Bertrand, s.d..

RIBEIRO, Gladys Sabina Ribeiro. A liberdade em construção: identidade nacional e conflitos antilusitanos no primeiro reinado. Rio de Janeiro: Relume Dumará. FAPERJ, 2006 
RIBEIRO, Maria Eurydice de Barros. Os símbolos do poder: cerimonias e imagens do Estado monárquico no Brasil. Brasília: Editora Universidade de Brasília, 1995.

ROMERO TOBAR, Leonardo; ALMARCEGUI ELDUYAEN, Patrícia (orgs.) Los libros de viaje: realidade vivida y género literário. Madri: Universidade de Andalucia, Akal, 2005.

ROUANET, Maria Helena. Eternamente em berço esplendido: a fundação de uma literatura nacional. São Paulo: Siciliano, 1991.

SCHIAVINATTO, Iara Lis. Imagens do Brasil: entre a natureza e a história. In: JANCSÓ, István. Brasil: formação do Estado e da nação. São Paulo: Hucitec, Fapesp, 2003.

SCHWARZ, Stuart B. Gente da terra brasiliense da nasção. Pensando o Brasil: a contrucao de um povo. in: MOTA, C. G. Viagem incompleta. A experiência brasileira. 2 ed. São Paulo: Senac, 2000.

SEBASTÍAN, Javier Fernández. (dir.). Diccionario político y social del mundo iberoamericano . La era de las revoluciones, 1750-1850. Fundación Carolina. Sociedad Estatal de Commemoraciones Culturales. Centro de Estudios Políticos y Constitucionales. Madri, 2009.

SILVA, Ana Rosa Cloclet da. Identidades em construção. O processo de politização das identidades coletivas em Minas Gerais, de 1792 a 1831. Almanack Braziliense (Online), São Paulo, v. 1, n. 1, p. 103-113, 2005.

SILVA, Cristina Nogueira da. "Nação federal ou Nação bi-hemisférica? O Reino Unido de Portugal, Brasil e Algarves e o modelo colonial português do século XIX". Almanack Braziliense n.9, maio de 2009.

SILVA, Dinair Andrade da. Viajantes estrangeiros, cultura e relações internacionais: August de Saint-Hilarie no Brasil, 1816-1822. Brasília: Casa das Musas, 2006.

SILVA, Maria Beatriz Nizza da. Cultura e sociedade no Rio de Janeiro (1808-1821). São Paulo: Nacional 1798.

SILVA, Luiz Geraldo. "O avesso da independência: Pernambuco (1817-24)". MALERBA, Jurandir (org.). A Independência brasileira: novas dimensões. Rio de Janeiro: Editora FGV, 2006, p.343-384..

SLEMIAN, Andréa. Vida política em tempo de crise: Rio de Janeiro (1808-1824). São Paulo: Hucitec, 2006. 
SLEMIAN, Andrea \& PIMENTA, João Paulo G.. A corte e o mundo. Uma história do ano em que a família real portuguesa chegou ao Brasil. São Paulo: Alameda, 2008.

. O" nascimento político" do Brasil: as origens do Estado e da nação (18081825). Rio de Janeiro: DP\&A, 2003.

O nascimento político do Brasil: origens do Estado e da Nação. Rio de Janeiro: DP\&A, 2003.

SMITH, Anthony. A identidade nacional. Trad. Claudia Brito. Lisboa: Gradiva, 1997.

SODRÉ, Nelson Werneck. História da Imprensa no Brasil. Rio de Janeiro: Mauad, 1966.

SOUSA, Maria Aparecida Silva de. Bahia: de capitania a província, 1808-1823. São Paulo: FFLCH-USP, 2007 (doutorado).

SOUZA, Iara Lis C. Pátria coroada: o Brasil como corpo político autônomo. São Paulo, EDUNESP, 1998.

STUMPF, Roberta Giannubilo. Filhos das Minas, americanos e portugueses: identidades coletivas na capitania de Minas Gerais (1763-1792). São Paulo: Hucitec, 2010.

SÜSSEKIND, Flora. O Brasil não é longe daqui. O narrador, a viagem. São Paulo: Companhia das Letras, 1990.

SZMRECSÁNVI, Tamás \& LAPA, José do A. (orgs.). História econômica da independência e do império. São Paulo: hucitec, 1996.

SCHWARCZ, Lilia Mortiz. Viajantes em meio ao império das festas. In: István Jancsó \& Iris Kantor (orgs.). Festa. Cultura e sociabilidade na América portuguesa. Vol.2. São Paulo: Hucitec

TEJERINA, Marcela. Luso-brasileños en el Buenos Aires virreinal: trabajo, negocios e intereses en la plaza naviera y comercial. Bahía Blanca: Ediuns, 2004.

THOMAZ, Luís F. De Ceuta a Timor. Lisboa: Difel, 1994.

VILLALTA, Luiz Carlos. 1789-1808: o impéiro luso-brasileiro e os Brasis. São Paulo:Cia. das letras, 2000.

. "Libertinagens e livros no mundo luso-brasileiro". ALGRANTI, L. M. \& MEGIANI, A. P. (orgs.). O império por escrito: formas de transmissão da cultura letrada no mundo ibérico. São Paulo: Alameda, 2009. 
VILLAR, Pierre. Reflexiones sobre los fundamentos de las estruturas nacionales. In: Hidalgos, amotinados y guerrilleros: pueblos y poderes en la historia de España. Barcelona: Grijalbo, 1982.

WALLERSTEIN, Immanuel. O sistema mundial moderno. 3v. Porto: Afrontamento 1974.

WASSERMAN, Fabio. "El concepto de nación e las transformaciones del orden político en Iberoamérica, 1750-1850”. In: SEBASTIÁN, Javier Fernández (dir.). Diccionario político y social del mundo iberoamericano. La era de las revoluciones, 1750-1850. Fundación Carolina/Centro de Estudios Políticos y Constitucionales. Madri, 2009,

WHITE, Hayden. Trópicos do discurso. Ensaio sobre a crítica da cultura. Trad. Alípio Correia Franca Neto. São Paulo: Edusp, 1994. 